\title{
ipen
}

INSTITUTO DE PESQUISAS ENERGÉTICAS E NUCLEARES Autarquia associada à Universidade de São Paulo

\section{EFEITO DA RADIAÇÃO GAMA SOBRE A VISCOSIDADE DE SOLUÇÕES DE GELATINA E PECTINA UTILIZADAS NA INDÚSTRIA DE ALIMENTOS}

PATRÍCIA YOKO INAMURA

Dissertação apresentada como parte dos requisitos para obtenção do Grau de Mestre em Ciências na Área de Tecnologia Nuclear Aplicações.

Orientadora:

Dra. Nélida Lucia del Mastro

SÃO PAULO

2008 


\section{INSTITUTO DE PESQUISAS ENERGÉTICAS E NUCLEARES}

Autarquia associada à Universidade de São Paulo

\section{EFEITO DA RADIAÇÃO GAMA SOBRE A VISCOSIDADE DE SOLUÇÕES DE GELATINA E PECTINA UTILIZADAS NA INDÚSTRIA DE ALIMENTOS}

\section{PATRÍCIA YOKO INAMURA}

Dissertação apresentada como parte dos requisitos para obtenção do Grau de Mestre em Ciências na Área de Tecnologia Nuclear Aplicações.

Orientadora:

Dra. Nélida Lucia del Mastro

SÃO PAULO 
Aos meus pais,

irmãos e ao Fernando com amor e carinho. 


\section{AGRADECIMENTOS}

À Prof ${ }^{a}$. Dra . Nélida Lucia del Mastro, pela orientação, dedicação e sabedoria, sempre zelando pelo melhor desempenho de todos os trabalhos e contribuindo para o crescimento profissional se seus orientados.

Ao IPEN-CNEN/SP e ao CTR por disponibilizar as instalações e equipamentos do centro para realização do meu trabalho.

À Elizabeth S. R. Somessari e ao Carlos Gaia da Silveira pelo imenso carinho, dedicação aos meus ensaios e às irradiações das minhas amostras.

Ao Dr. Wilson Aparecido Parejo Calvo e $\mathrm{Dr}^{\mathrm{a}}$. Margarida Mizue Hamada por possibilitar a realização do meu trabalho.

Ao pesquisador Prof. Dr. Heleno Bolfarini e seus alunos Denis Guilherme Alberghini e Rafael Leite Neves Roza pela preciosa contribuição para realização da análise estatística dos dados.

Aos colegas do Centro de Tecnologia das Radiações pela amizade, ajuda e por ter proporcionado um ambiente de trabalho tão agradável.

Aos amigos presentes em meus pensamentos, pela importância que tem em minha vida.

Ao meu querido Fernando, pelo amor, compreensão e cumplicidade e a sua família: Cecília, Ernesto e Enzo pela agradável convivência.

Aos meus queridos irmãos Míriam, Adelmo, Cristina e Fábio, sempre presentes e unidos em minha vida.

Em especial aos meus queridos pais, Yoshio e Natália, meus avós Fumio e Tsuruyo (em memória), Kikuo (em memória) e Sadaco e meus familiares, que apesar da distância estão sempre presentes em minha vida e me dão força para seguir em frente. 


\title{
EFEITO DA RADIAÇÃO GAMA SOBRE A VISCOSIDADE DE SOLUÇÕES DE GELATINA E PECTINA UTILIZADAS NA INDÚSTRIA DE ALIMENTOS
}

\author{
Patrícia Yoko Inamura
}

\section{RESUMO}

A pectina é uma substância polissacarídica originada de plantas, que pode ser utilizada como agente gelificante, estabilizante de compotas, em bebidas láticas e iogurtes. A gelatina, proteína, nesse caso de origem bovina, é principalmente utilizada como agente gelificante, pois, forma hidrogéis por resfriamento. $O$ processo de irradiação por radiação gama pode causar uma variedade de modificações nas macromoléculas algumas de aplicação industrial, como é o caso de reticulação. A resposta dinâmica de materiais viscoelásticos pode ser usada para dar informação sobre o aspecto estrutural de um sistema a nivel molecular. No presente trabalho, pectina com diferentes graus de metoxilação, gelatina e a mistura de ambas foram empregados para estudar a sensibilidade à radiação por meio de medidas de viscosidade. Amostras de soluções de pectina de alto teor de metoxilação (ATM) $1 \%$, pectina de baixo teor (BTM) $1 \%$, gelatina $0,5 \%, 1 \%$ e $2 \%$, e a mistura de ambas a $1 \%$ e $2 \%$ foram irradiadas com raios gama em doses de até $15 \mathrm{kG}$ e taxa de dose em torno de $2 \mathrm{kGy} / \mathrm{h}$. Após irradiação, a viscosidade foi medida dentro de um período de $48 \mathrm{~h}$. A viscosidade da pectina ATM e BTM diminuiu drasticamente com o aumento da dose de radiação. A gelatina, entretanto, apresentou grande resistência à radiação. $\mathrm{Na}$ mistura de ambas, houve predomínio do comportamento esperado para a pectina. 


\title{
EFFECT OF GAMMA IRRADIATION IN THE VISCOSITY OF GELATIN AND PECTIN SOLUTIONS USED IN FOOD INDUSTRY
}

\author{
Patrícia Yoko Inamura
}

\begin{abstract}
Pectin is a polysaccharide substance of plant origin that may be used as gelling agent, stabilizer in jams, in yogurt drinks and lactic acid beverages. Gelatin, a protein from bovine origin, in this case, is mainly used as gelling agent due to hydrogel formation during cooling. The ${ }^{60} \mathrm{Co}$-irradiation process may cause various modifications in macromolecules, some with industrial application, as reticulation. The dynamic response of viscoelastic materials can be used in order to give information about the structural aspect of a system at molecular level. In the present work samples of pectin with different degree of methoxylation, gelatin and the mixture of both were employed to study the radiation sensitivity by means of viscosity measurements. Solutions prepared with citric pectin with high metoxylation content (ATM) $1 \%$, pectin with low content (BTM) $1 \%$, gelatin $0.5 \%, 1 \%$ and $2 \%$, and the mixture $1 \%$ and $2 \%$ were irradiated with gamma rays at different doses, up to $15 \mathrm{kGy}$ with dose rate about $2 \mathrm{kGy} / \mathrm{h}$. After irradiation the viscosity was measured within a period of $48 \mathrm{~h}$. The viscosity of ATM and BTM pectin solutions decreased sharply with the radiation dose. However, the gelatin sample presented a great radiation resistance. When pectin and gelatin solutions were mixtured a predominance of pectin behavior was found.
\end{abstract}




\section{SUMÁRIO}

\section{Página}

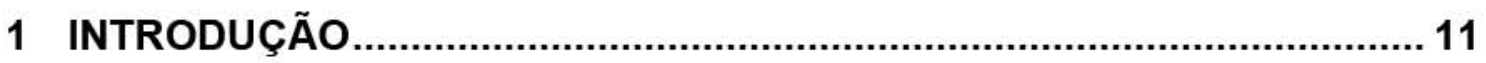

2 OBJETIVO

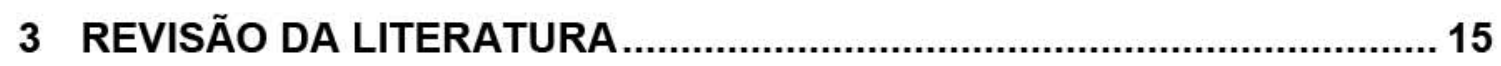

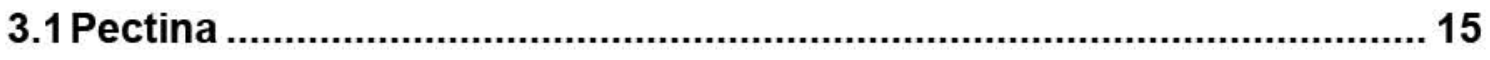

3.1.1Características da Pectina................................................................... 16

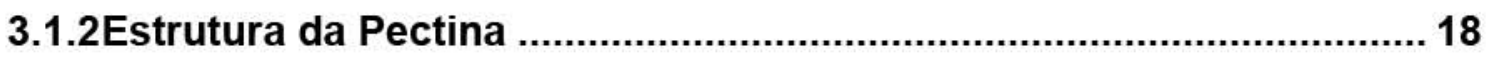

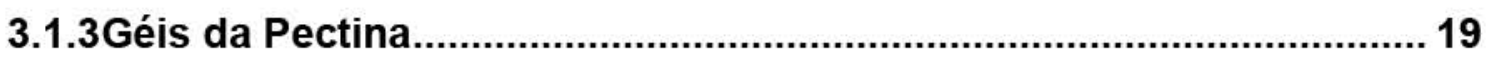

3.1.4Outras Propriedades da Pectina .......................................................... 22

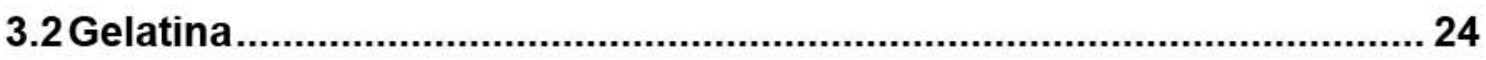

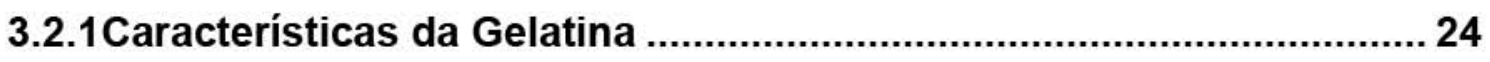

3.3 Aplicações de Pectina e Gelatina como Biopolímeros Biodegradáveis..

3.4 Tecnologia das Radiações lonizantes..................................................... 30

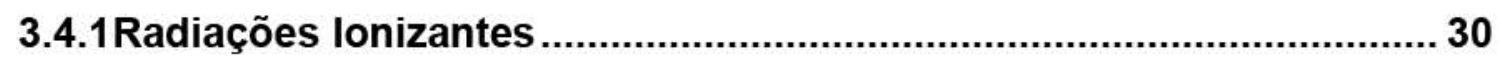

3.4.2Interação da radiação com água, proteínas e polissacarídeos........... 32

3.4.3Processamento de Alimentos pela Radiação ………........................... 34

3.4.4Legislação de Alimentos Irradiados ...................................................... 38 
3.5.1Definição e Medida da Viscosidade ................................................... 39

3.5.2Fluidos Newtonianos ..................................................................... 42

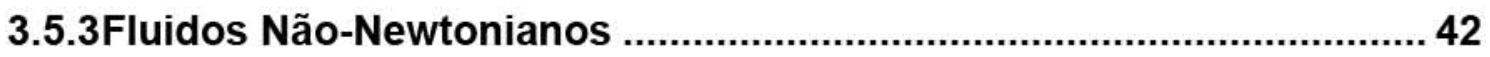

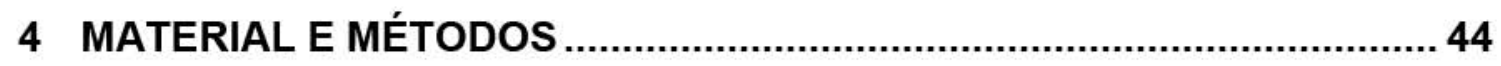

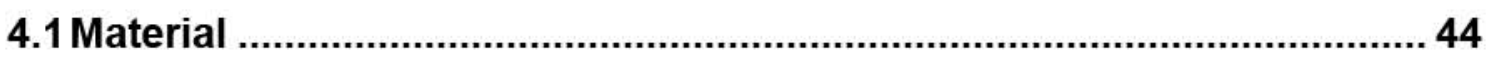

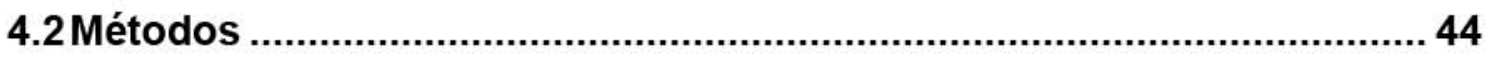

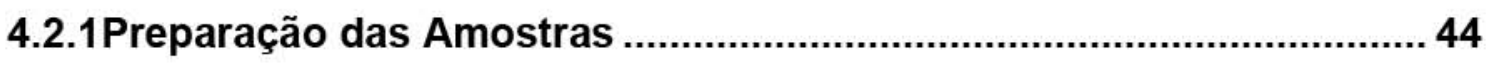

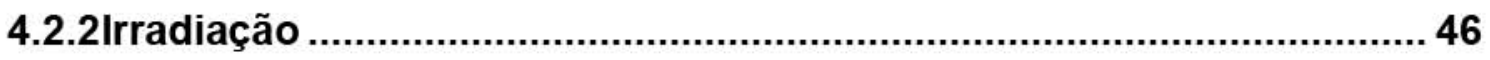

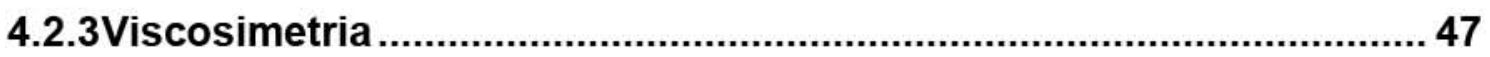

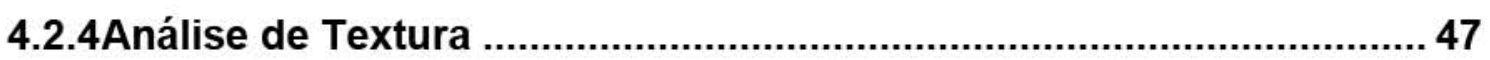

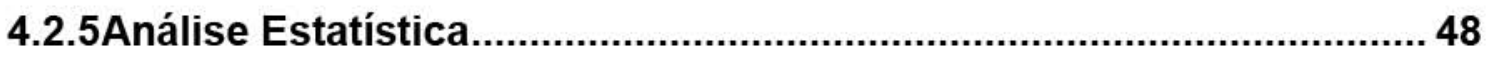

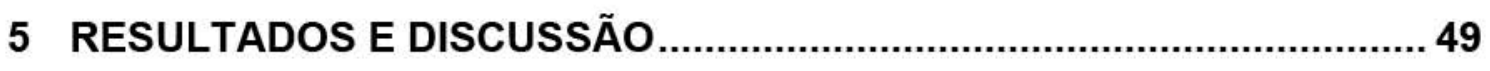

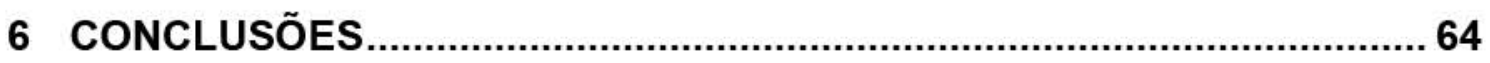

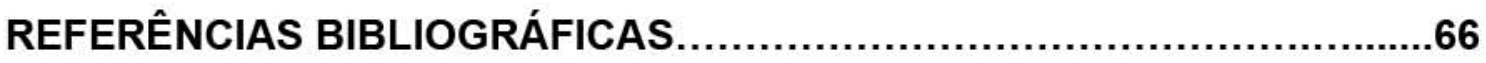




\section{LISTA DE TABELAS}

Página

TABELA 1 - Unidades de dose de radiação e radioatividade.

TABELA 2 - Aplicações da irradiação de alimentos. 36

TABELA 3 - Concentração das amostras e os respectivos valores de pH das amostras não-irradiadas e irradiadas a $5 \mathrm{kGy}$. 57 


\section{LISTA DE FIGURAS}

Página

FIGURA 1 - Estrutura da pectina.

FIGURA 2 - Estrutura química da gelatina.

FIGURA 3 - Produção mundial de gelatina.

FIGURA 4 - Exemplo de fluido newtoniano.

FIGURA 5 - Exemplo de fluido não-newtoniano pseudoplástico.

FIGURA 6 - Etapas da preparação de amostra até a irradiação.

FIGURA 7 - Etapas da análise de viscosidade mediante o uso do viscosímetro Brookfield.

FIGURA 8 - Distribuição dos dados de viscosidade, tensão de cisalhamento e torque de todas as amostras estudadas.

FIGURA 9 - Relação entre a viscosidade e tensão de cisalhamento de todas as amostras. 50

FIGURA 10 - Tensão de cisalhamento em função do torque (\%) de todas as amostras. 50

FIGURA 11 - Relação da viscosidade de todos os compostos e o torque (\%)..

FIGURA 12 - Relação da viscosidade com a dose de radiação de soluções de gelatina $0,5 \%, 250 \mathrm{rpm}$ a 50,60 e $70^{\circ} \mathrm{C}$

FIGURA 13 - Relação da viscosidade com a dose de radiação de soluções de gelatina $1 \%, 250 \mathrm{rpm}$ a 50,60 e $70{ }^{\circ} \mathrm{C}$ 
FIGURA 14 - Viscosidade vs dose da Gelatina 2\%, $250 \mathrm{rpm}$ a 50, 60 e $70{ }^{\circ} \mathrm{C}$.

FIGURA 15 - Típico perfil de força-distância de gelatina a 1\% em diferentes doses pela análise de textura. 54

FIGURA 16 - Viscosidade vs dose das pectinas ATM e BTM a 1\%, $250 \mathrm{rpm}$ a 50,60 e $70^{\circ} \mathrm{C}$.

FIGURA 17 - Viscosidade vs dose da solução $1 \%$ de mistura gelatina e pectina (1:1), a $180 \mathrm{rpm}$ a 50,60 e $70^{\circ} \mathrm{C}$

FIGURA 18 - Viscosidade vs dose da solução $1 \%$ de mistura gelatina e pectina (1:1), a $250 \mathrm{rpm}$ a 50,60 e $70^{\circ} \mathrm{C}$

FIGURA 19 - Viscosidade vs dose da solução $2 \%$ de mistura gelatina e pectina (1:1), a $180 \mathrm{rpm}$ a 50,60 e $70^{\circ} \mathrm{C}$ 60

FIGURA 20 - Viscosidade das amostras vs dose de radiação. Perfis das médias, $250 \mathrm{rpm}$ a 50,60 e $70^{\circ} \mathrm{C}$

FIGURA 21 - Viscosidade de soluções de pectina BTM a 1 e $3 \%$ e adição de $\mathrm{CaCl}_{2}$ em concentrações diferentes. 62

FIGURA 22 - Influência da concentração na viscosidade das soluções de pectina e gelatina e suas misturas não irradiadas. 63 


\section{INTRODUÇÃO}

A busca pela satisfação do consumidor e demanda do mercado, levam as indústrias de alimentos à constante inovação e desenvolvimento de novos produtos. Entre eles, os alimentos funcionais, os quais possuem propriedades nutricionais que podem trazer benefícios à saúde e bem estar ao consumidor. Para esse propósito, mais de 20 principais hidrocolóides são utilizados para modificar texturas e aspectos de qualidade durante 0 processamento e fabricação. A pectina e a gelatina são ingredientes usados com propriedade de gelificação e estabilizante.

A biotecnologia é a aplicação de conhecimentos químicos e biológicos e de novas tecnologias nas áreas da saúde, de alimentos, química e ambiental. Particularmente em indústrias alimentícias e farmacêuticas vem contribuindo com as inovações tecnológicas que essas áreas exigem (Borém, 2005).

A pectina e a gelatina são dois aditivos ou ingredientes alimentares utilizados amplamente na indústria de alimentos pela sua capacidade de formar hidrogéis (Zegota, 1999).

As substâncias pécticas ocorrem na maioria dos tecidos vegetais, principalmente em tecidos macios como os frutos e são polissacarídeos formados em grande proporção por unidades derivadas do ácido galacturônico. Nos vegetais, desempenham um importante papel na lamela média da parede celular (Skinner \& Kertesz, 1960; Zegota, 1999), auxiliando na manutenção da união celular junto à celulose, hemicelulose e glicoproteínas.

Apesar de ampla ocorrência, poucos materiais são usados para produzir a pectina comercial para o seu emprego na indústria de alimentos. A pectina comercial é obtida do albedo da laranja ou limão (Yoshimura et al., 2005), que contém aproximadamente $30 \%$ desse polissacarídeo. Essa frutas 
são consideradas entre as fontes mais ricas em pectina, juntamente com a maçã, sementes de girassol, tomate, beterraba, entre outras. A pectina do limão é a mais fácil de ser isolada e apresenta a melhor qualidade.

A gelatina, por sua vez, é uma mistura de proteínas de origem animal solúveis em água. Ela não é encontrada in natura, mas deriva do colágeno por ação hidrolítica. Como hidrogel, tem sido por muitos anos motivo de amplos estudos. Dados relevantes vêm sendo acumulados a respeito das propriedades dos géis formados em várias condições, algumas aplicáveis na química de alimentos (Meyer, 1975). Como toda proteína, a gelatina é um heteropolímero formado por ao redor de 20 aminoácidos. Por causa dessa diversidade molecular, as proteínas apresentam considerável potencial para a formação de diferentes ligações químicas dependendo da posição, natureza e energia.

A aplicação da radiação ionizante em produtos alimentícios vem crescendo nos últimos anos (Diehl, 2002). Este tratamento induz mudanças químicas nos componentes do alimento, que podem diferir do efeito sobre os mesmos componentes quando estes se encontram isolados. As mudanças químicas freqüentemente envolvem reações de decomposição que dão origem a novas espécies químicas de menor massa molecular. Por outro lado, dependendo do produto e das condições de irradiação, pode haver formação de agregados com maior massa molecular.

Um método analítico tradicional aplicado para acompanhar mudanças na massa molecular é a viscosimetria. As mudanças de massa molecular frequentemente podem ser visualizadas por mudanças na viscosidade dos mais variados sistemas (Baxendale et al., 1946; Carter et al., 1946; Donnan \& Rose, 1950; Cox et al., 1957; Kumar et al., 2004; Anttila et al., 2004; Pong et al., 2005).

Um novo rumo de pesquisas indica que a combinação de substâncias protéicas e polissacarídicas que já são utilizadas em alimentos poderiam conduzir a uma melhor estabilização dos produtos, otimização da formulação do alimento e incremento da qualidade de coberturas comestíveis. 
O estudo inicial da viscosidade desses aditivos alimentares é fundamental para uma posterior aplicação nos processos biotecnológicos. O conhecimento da ação da radiação nestes ingredientes ou aditivos alimentares é restrito e precisa ser aprofundado. Por outro lado, esses dados serão de extrema valia para o desenvolvimento posterior de formulações de produtos alimentícios adequados para serem submetidos a tratamento por radiação. 


\section{OBJETIVO}

O objetivo do presente plano de dissertação de mestrado é o estudo da ação da radiação ionizante de Co-60 em dois importantes ingredientes alimentícios naturais utilizados como gelificantes, pectina e gelatina e na mistura de ambas substâncias. A metodologia a ser utilizada será o estudo da variação de viscosidade das soluções/suspensões desses aditivos induzidas pela radiação, uma vez que a viscosidade é a principal característica desses produtos. 


\section{REVISÃO DA LITERATURA}

\subsection{Pectina}

Chama-se pectina a qualquer substância incolor, amorfa, metilada pertencente ao grupo das substâncias pécticas que ocorrem em tecidos vegetais (Skinner \& Kertesz, 1960; Maftoonazad et al., 2007) ou são obtidas por tratamento restrito da protopectina (por meio da protopectinase ou ácido) e que é encontrada ou obtida a partir de frutas ou vegetais suculentos (Agnes, 1976). Substâncias pécticas incluem qualquer integrante dos grupos derivados de carboidratos complexos coloidais de origem vegetal contendo uma grande proporção de unidades de ácido galacturônico e subdivididas em protopectinas, pectinas, ácidos pectínicos e ácidos pécticos (Merriam, 1976). Essa grande classe de substâncias pécticas envolve substâncias com altos teores de unidades neutras de açúcares ou substituídas com acetil ou outros grupos que evitam a gelificação. Por esse motivo, delimita-se a produção da pectina comercial em alguns alimentos que possuam essas substâncias pécticas presentes naturalmente com a propriedade funcional de gelificar (Steven, 1983).

De acordo com a Associação Internacional de Produtores de Pectina (IPPA), a sua produção mundial é de 35.000 toneladas por ano ${ }^{1}$.

São consideradas boas fontes de pectina: as maçãs, as frutas cítricas, as uvas, bagas ou sementes e farelo. Em contraste à pectina cítrica e de maçã que possuem alto grau de metil-esterificação (Fishman et al., 2004), as sementes de girassol possuem baixo grau (Harry \& Smith, 2006).

\footnotetext{
${ }^{1}$ http://www.ippa.info/
} 


\subsubsection{Características da Pectina}

As propriedades e composições da pectina variam com a fonte, o processo de manuseio utilizado e de secagem do albedo, o tipo de extração e os tratamentos subseqüentes (Ribeiro, Seravalli, 2004). Durante a extração com ácido fraco, ocorrem algumas despolimerizações hidrolíticas e a hidrólise de grupos metil ésteres. A produção do hidrogel é feita a partir do albedo de citros. Este é extraído com água em pH de 1,5 a 3,0 e a uma temperatura que varia entre 60 a $100{ }^{\circ} \mathrm{C}$. Através de um pré-tratamento com microondas, as propriedades físicas do tecido da laranja podem sofrer alterações. Foi encontrado também que a superfície específica e a capacidade de absorção de água dos tecidos da laranja, e as enzimas endógenas do albedo foram inativadas (Kratchanova, Pavlova, Panchev, 2004).

Embora a pectina seja obtida preferencialmente de citros, há referências da sua promissora obtenção a partir de outras frutas, como por exemplo, manga (Berardini et al., 2005; Banjongsinsiri et al., 2004; Sudhakar \& Maini, 2000).

O grupo das substâncias pécticas abrange substâncias com diferentes propriedades e difíceis de serem separadas uma das outras. Um aspecto que as diferencia é o seu grau de metoxilação e grupos metilas esterificados aos ácidos carboxílicos da macromolécula polissacarídica. O grau de esterificação é definido como 100 vezes a razão entre o número de resíduos de ácido galacturônico esterificados e o número total de resíduos de ácido galacturônico.

A pectina, ácidos pectínicos com número de metoxilas e grau de metoxilação variáveis, é capaz de formar géis na presença de sacarose em meio ácido ou na presença de íons cálcio. Devido a essa propriedade é que a pectina tem sido muito utilizada na produção de geléias e doces de frutas (Zegota, 1999).

Existem três tipos de enzimas pécticas que agem nas substâncias pécticas. Duas delas, pectinesterase e a poligalacturonase, são encontradas em plantas e microorganismos e as pectatoliases são encontradas em 
microorganismos, especialmente em patogênicos que infectam as plantas. Há evidências que sugerem existir ainda mais de um tipo de pectinesterase e a poligalacturonase numa determinada fruta (Labib et al., 1995).

As enzimas pécticas podem ser destruídas pelo calor a fim de manter uma opacidade estável, desejável, e a viscosidade. Nos sucos de uva e maçã, o desejável é que eles se mantenham claros ou transparentes; para isso, utiliza-se a enzima pectinesterase. Acrescentando a enzima ao suco a viscosidade diminui e a pectina é degradada, permitindo às partículas insolúveis e divididas flocularem.

A pectina é utilizada em confeitaria e bebidas (Zegota, 1999). O uso em bebidas acidificadas vem crescendo devido a sua boa estabilidade em baixos valores de $\mathrm{pH}$. O seu uso não está restrito apenas para fins alimentícios, mas é também utilizada na tecnologia farmacêutica, adesivos, filmes comestiveis, coberturas e como fibra.

Fibra alimentícia é o resíduo indigerivel das células vegetais, constituído de celulose, hemicelulose, pectina, lignina, gomas e mucilagos. Alguns componentes dessas fibras são denominados prebióticos, chegando intactos ao intestino grosso, sem ter sofrido nenhum tipo de degradação ou absorção, e lá são metabolizados seletivamente, por um número limitado de bactérias benéficas, gerando uma microbiota bacteriana saudável, capaz de induzir efeitos fisiológicos importantes para a saúde.

Os denominados prebióticos são, na verdade, alguns tipos de fibras encontradas em certos alimentos, ou seja, carboidratos não digeríveis pelo organismo, portanto resistentes à ação de enzimas no processo digestivo. Exemplos de prebióticos são: frutooligossacarídeos (FOS), a pectina, as ligninas e a inulina. A ingestão de prebióticos tem mostrado reduzir a taxa de infecção e restauração da saúde de enfermos e pacientes pós-operatórios. (Bengmark, 2003).

A pectina é considerada capaz de diminuir o colesterol, auxiliar na eliminação de ácidos biliares através do trato intestinal e prevenir o desenvolvimento de pedras na vesícula biliar. Numerosos estudos comprovam 
a eficácia da pectina na redução do colesterol do tipo LDL (Cerda et al., 1988; Zegota, 1999), reconhecidamente nocivo, sem alterar os níveis de HDL, o bom colesterol $^{2}$. A pectina atua como adsorvente, isto é, ela fixa em sua superfície moléculas de uma outra, juntando os componentes dos fluidos digestivos secretados pelo fígado e pela vesícula biliar. Este hidrogel beneficia também os diabéticos, pois forma uma espécie de barreira nas paredes do intestino, impedindo a passagem do excesso de glicose, auxilia na eliminação de resíduos de substâncias altamente tóxicas e também constitui uma proteção bastante eficaz contra os efeitos tóxicos de certos produtos dietéticos, como os ciclamatos, além de ajudar em disfunções gastrintestinais. Outras aplicações da pectina incluem no uso de filmes comestíveis, substitutos de papel e espumas (Thakur et al., 1997).

\subsubsection{Estrutura da Pectina}

A estrutura química das pectinas influencia no desenvolvimento da planta, em seu processo de maturação, de processos tecnológicos alimentícios e em sua função como fibra alimentar (Yuste \& Garza, 1993).

A massa molecular da pectina varia entre $20.000-400.000 \mathrm{~g} / \mathrm{mol}$ (Windholz et al., 1983), e a sua funcionalidade dependente da sua massa molecular, do grau de metoxilação (Pilnik apud Zegota, 1999), pH, temperatura, distribuição das cargas, número de cadeias laterais, sua disposição e da força iônica. A pectina é constituída basicamente por unidades

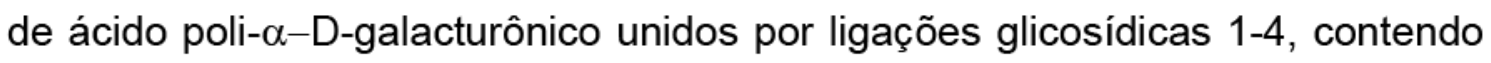
vários grupos de metil éster, ligados a seqüências de D-poligalacturonase interrompidas com resíduos de (1-2)-L-ramnose (Zegota, 1999; Fishman et al., 2000; Goycoolea \& Cárdenas, 2001; Jo et al., 2005; Park \& Zhao, 2006; Kang et al., 2007; Maftoonazad et al., 2007; Kaaber et al., 2007; Guillotin et al., 2007). Açúcares neutros como: D-galactose, L-rabinose, D-xilose e L-fucose

${ }^{2}$ http://www.laranjabrasil.com.br/default.htm?link=search\&pagina=pesquisa\&query=pectina\&go. $x=23 \& g o . y=14$ 
formam as cadeias laterais na molécula de pectina (Windholz et al., 1983). Algumas pectinas contêm cadeias de arabinogalactanas ramificada ou cadeias curtas compostas de unidades de D-xilose na ramnogalacturonoglicana. As unidades de ramnopiranosila podem ocasionar irregularidades na estrutura que limita o tamanho das zonas de junção, afetando a gelificação.

O termo pectina é normalmente usado de forma genérica para designar o preparo de galacturonoglicanas hidrossolúveis com graus variáveis de ésteres metílicos e de neutralização que estão susceptíveis à formação de géis. Alguns dos grupos carboxilas desses hidrogéis estão metilados, alguns estão na forma livre e outros na forma de sais de sódio, potássio ou amônio, mais frequentemente na forma de sal de sódio. A seguir, será apresentada a estrutura da pectina na FIG.1.

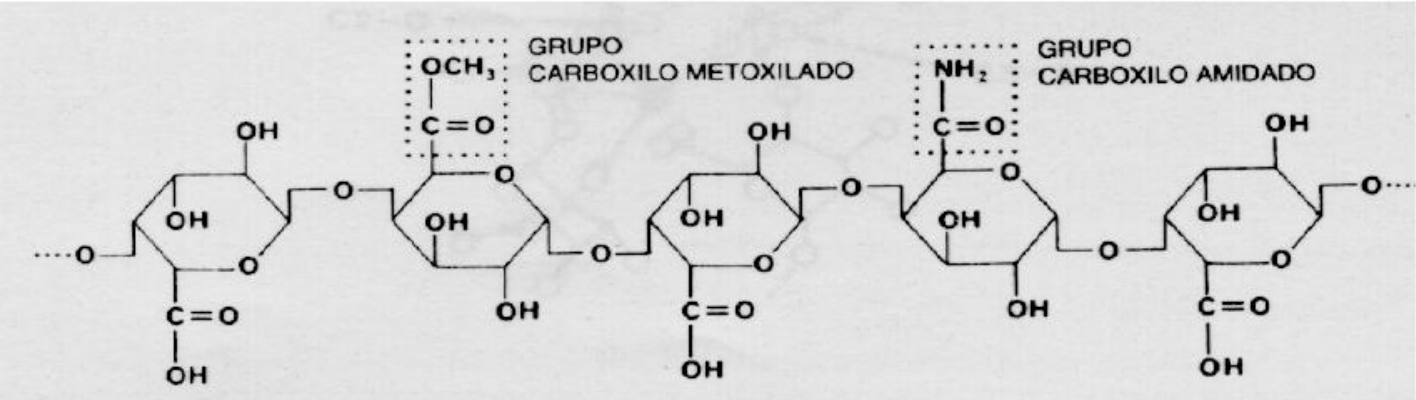

FIGURA 1 - Estrutura da pectina

\subsubsection{Géis da Pectina}

As pectinas são caracterizadas de acordo com o seu grau de metil esterificação ou metoxilação (GM), que significa a porcentagem de grupos carboxílicos esterificados com metanol (Ramírez et al., 2005), e esse grau tem um importante efeito em sua funcionalidade (Harry \& Smith, 2006). A metoxilação dos grupos de ácidos carboxílicos forma metil ésteres, os quais ocupam um espaço similar, mas são mais hidrofóbicos e consequentemente tem um diferente efeito na estrutura que circundam a água. Pectinas com GM superior a 50\% (Goycoolea \& Cárdenas, 2001; Harry \& Smith, 2006), ou seja, 
com mais da metade de grupos carboxílicos na forma metil éster $\left(-\mathrm{COOCH}_{3}\right)$, são denominadas de pectinas com alto teor de metoxilas (ATM). Já aquelas com GM inferior a $50 \%$ são denominadas de pectinas com baixo teor de metoxilas (BTM). Em ambos os casos, os grupos carboxilas remanescentes estão presentes como mistura na forma de ácidos livres $(-\mathrm{COOH})$ e sais $\left(-\mathrm{COO}^{-} \mathrm{Na}^{+}\right)$. O grau de amidação indica a porcentagem de grupos carboxilas na forma amida (Black \& Smit, 1972). Os graus de metoxilação e de amidação influenciam fortemente as propriedades funcionais, tais como: solubilidade, capacidade de gelificação e temperatura, e condições de gelificação das pectinas (Ribeiro, Seravalli, 2004).

O tratamento da pectina com amônia dissolvida em metanol converte alguns dos grupos metoxilas em grupos carboxilicos. Através deste processo são produzidas as pectinas BTM. As pectinas amidadas podem apresentar de 15 a $25 \%$ dos grupos carboxílicos na forma de grupos carboxiamidas. Em meio alcalino a pectina é desmetoxilada, tornando-se mais solúvel devido à perda das metoxilas e em meios ácidos fortes as ligações glicosídicas da pectina $(1,4)$ são hidrolisadas (Ribeiro, Seravalli, 2004).

A principal forma de obtenção da pectina ATM (alto teor de metoxilação) é através da sua extração de frutas cítricas com ácidos diluídos. Esse processo é utilizado, também, com o intuito de manter o grau de metoxilação. A pectina pode ser tratada com reagente alcalino ou com enzima e desmetoxilada, produzindo a pectina com baixo teor de metoxilas (menor que $50 \%$ ), a pectina BTM (Ribeiro, Seravalli, 2004).

As variações em número e na natureza das ligações cruzadas, na flexibilidade da estrutura, na atração e repulsão entre os componentes da rede e nas interações com o solvente, dão espaço a diferentes mecanismos de gelificação para polímeros alimentícios e géis com características distintas, com o que se pode obter uma gama de estruturas, desde sistemas muito simples até as redes mais complexas (Thakur et al., 1997).

O mecanismo de gelificação da pectina não está totalmente elucidado, embora tenha sido feito um significativo progresso nessa direção 
(Thakur et al., 1997). A gelificação da pectina ATM ocorre mediante ligações hidrofóbicas e pontes de hidrogênio entre os grupos metiléster do ácido carboxilico e o da pectina BTM ocorre pela interação entre os íons cálcio e os grupos carboxílicos do ácido galacturônico.

Para ocorrer a gelificação da pectina ATM é necessário que o $\mathrm{pH}$ da solução esteja ajustado na faixa de 2,8 - 3,5 e na presença de sacarose em uma concentração tal que o teor de sólidos solúveis da solução seja superior a $55 \%$. Assim, quando a solução resfria ela forma o gel (Jo et al., 2005), que mantém sua característica mesmo quando reaquecido a temperaturas próximas a $100^{\circ} \mathrm{C}$. Em valores muito baixos de $\mathrm{pH}$, menor do que 2,0, a pectina é hidrolisada.

As pectinas BTM podem formar géis na ausência de açúcares, mas requerem a presença de íons bivalentes, como o cálcio, os quais provocam a formação de ligações cruzadas entre as moléculas. Elas são mais adequadas em produtos de baixas calorias ou dietéticos. A pectina BTM é menos sensível ao $\mathrm{pH}$ do que a ATM, pode formar géis na faixa de 2,5 a 6,5. Como foi citado anteriormente, a pectina BTM não necessita de açúcar como a ATM para formar gel, porém tende a formar um gel quebradiço e menos elástico (Ribeiro, Seravalli, 2004).

Existem pectinas de rápida, média e lenta gelificação e quanto maior a sua massa molecular, maior é a rigidez do gel. (CP Kelco, 2004).

Através da determinação da rigidez e das ligações do chitosan na formação da rede do gel, foi examinado o efeito da concentração desse aditivo na gelificação da pectina, onde difere na carga de densidade e distribuição. $O$ chitosan age como ligante da solução de pectina concentrada com eficácia mostrando uma dependência na carga da pectina (Marudova, MacDougall, Ring, 2004). 


\subsubsection{Outras Propriedades da Pectina}

A pectina pode ser utilizada como importante auxiliar no tratamento de contaminações radiativas. Este polissacarídeo mostrou capacidade de ser usado como um descontaminante interno pela sua propriedade de sequestrar radionuclídeos (Bandazhevskaya et al., 2004).

De acordo com dados do centro local de controle de radiação (LCRC) e do serviço sanitário do estado de Belarus, aproximadamente $25 \%$ das mercadorias e alimentos produzidos na localidade estavam contaminados com Césio-137 devido à catástrofe sofrida em Chernobyl ${ }^{3}$. Por esse motivo, a tarefa prioritária de proteção da população foi a minimização da dose de exposição coletiva através de tratamento fácil e acessível para crianças com o fornecimento de medicamento à base de pectinas, as quais são capazes de se ligar aos radionuclídeos e deixá-los sair facilmente do organismo. A eficácia do medicamento à base de pectina é provada por pesquisas executadas naquele instituto, medindo o nível de acúmulo de radionuclídeos no organismo das crianças, antes e depois de tomarem o medicamento. O medicamento pode reduzir $30-40 \%$ a presença de Cs-137 no corpo humano durante 20-25 dias ${ }^{3}$.

Como resultado de testes clínicos, houve mudanças dos microelementos do sangue das pessoas que tomaram o preparado de pectina. Foi descoberto que esse preparado foi capaz de influenciar ativamente o balanço microelementar do organismo pela expulsão os metais pesados e radionuclídeos (chumbo e níquel 20 - 69\%, radionuclídeos - 28\%) do sangue e tecidos $^{4}$. Além disso, o preparado é capaz de normalizar troca dos microelementos vitais do corpo, tais como zinco, cobre através da influência no sistema unido microelementar do corpo homeostase.

Outro estudo relatado na literatura mostrou que a pectina comercial utilizada na fabricação de geléias e gelatinas de maçãs e limões pode ser usada como tratamento contra a contaminação radioativa, desde que essa

\footnotetext{
${ }^{3}$ http://www.comite-andajevsky.org/zzz angl/sciences publications/pectin project.htm

${ }^{4}$ http://www.fortunecity.com/boozers/vines/860/Nester/english/nester1.htm
} 
variedade não inclua outros aditivos. Pesquisadores russos estão convencidos de que a pectina em sementes pode impelir o estrôncio pelo corpo, evitando que ele seja absorvido. Uma pesquisadora da União Soviética usou sementes de girassol como fonte de pectina para atrair, ligar e eliminar a contaminação radiativa do sistema ${ }^{5}$. Outras fontes de pectina produzem produtos saudáveis, os quais ajudam a eliminar toxinas e são usados em pequenas sessões de desintoxicação. É um volume de gel vegetal contendo uma grande quantidade de pectina. Ela absorve, adsorve (atrai e liga) e remove várias toxinas do trato intestinal $^{5}$. E também é útil na eliminação da radioatividade. Outras sementes além das de girassol têm sido úteis.

$\mathrm{Na}$ Alemanha, sementes de trigo-macho e painço são considerados preventivos de radiação. Kelp, como foi denominado o medicamento à base de pectina, tem sido testado pela Universidade McGill, no Canadá, e descobriu-se um agente ligante, que remove radioatividade do intestino. Ele reduziu, por exemplo, a absorção de Estrôncio-90 por animais de $50 \%$ a $80 \%$ comparado com animais que não receberam o Kelp ${ }^{5}$. Os animais tratados com Kelp mostraram uma queda de $70 \%$ de absorção no osso e $60 \%$ nos níveis de sangue. Assim, Kelp pode ser considerado um verdadeiro antagonista da radiação. Nesse mesmo estudo, foi corroborado que a pectina da maçã também ajuda a ligar e limpar os metais e toxinas do intestino.

A pectina modificada desacelerou o tempo de duplicação do antígeno específico da próstata (PSADT) em um pequeno grupo de pacientes de câncer de próstata (Pienta apud Zegota, 1999). PSA é o marcador sanguíneo do câncer, e o tempo que o PSA leva para se duplicar é usado para prognosticar a progressão do câncer ${ }^{6}$.

\footnotetext{
${ }_{6}^{5} \mathrm{http}: / / \mathrm{www} \cdot \mathrm{mind}$ controlforums.com/rad $8 . \mathrm{htm}$

${ }^{6}$ http://www.lef.org/whatshot/\#mcpa
} 


\subsection{Gelatina}

\subsubsection{Características da Gelatina}

A gelatina é um ingrediente alimentar utilizado amplamente na indústria de alimentos pela sua capacidade de formar hidrogéis. $O$ uso da gelatina não está restrito apenas a alimentos e tecnologia farmacêutica (Yang et al., 2007), mas também na fabricação de substituintes da borracha, adesivos, filmes fotográficos e agentes clarificantes. Ela é uma mistura de proteínas de origem animal solúvel em água. Não é encontrada in natura, mas provém do colágeno por denaturação térmica e ação hidrolítica (Windholz et al., 1983). A gelatina é uma mistura heterogênea de polipeptídeos de cadeia simples ou múltiplas cada uma contendo entre 300 a 4000 aminoácidos. A gelatina é rica em resíduos de glicina (quase 1 em 3), prolina e de 4-hidroxiprolina, mas nutricionalmente é deficiente em isoleucina, metionina, treonina e triptofano. A estrutura típica é: -Ala-Gly-Pro-Arg-Gly-Glu-4Hyp-Gly-Pro- (Chaplin, 2007), como é mostrado na FIG. 2.

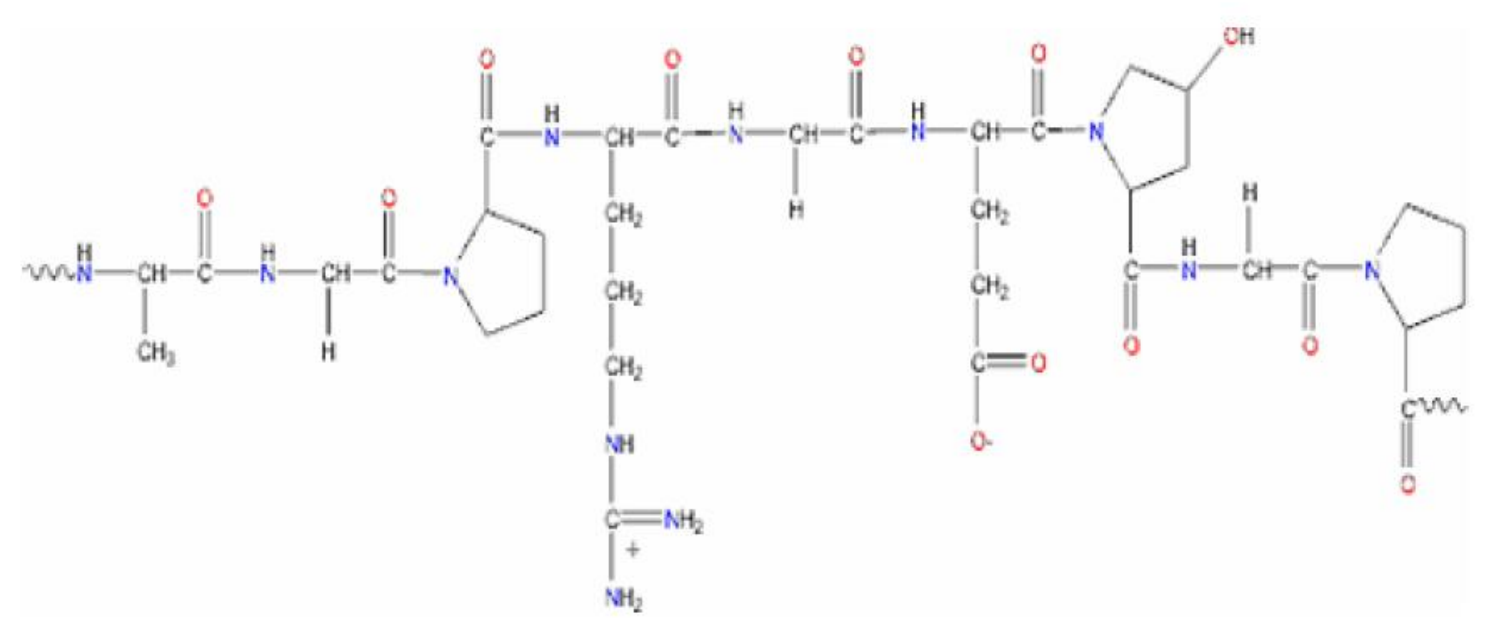

Fonte: www.niroinic.com/images/chem/chemicalGelatinFigure1

FIGURA 2 - Estrutura química da gelatina. 
As propriedades da gelatina são determinadas por sua estrutura, os quais dependem não apenas da seqüência de proteínas, mas também do conteúdo relativo de vários componentes interruptos de colágeno e seu estado de agregação (Yang et al., 2007). É também uma substância translúcida, insípida, incolor e inodora (Schrieber \& Gareis, 2007), que pode ser obtida pré-tratando o colágeno bovino ou suíno, ossos, peles, ligamentos e chifres com ácido ou base forte para quebrar a estrutura celular e liberar a proteína como colágeno (Chaplin, 2007). Após o pré-tratamento a mistura é submetida à fervura e durante esse processo, o colágeno rompe parcialmente suas ligações resultando na gelatina. Ela é facilmente extraída, pois forma-se uma camada na superfície da mistura em fervura.

A gelatina é solúvel em água quente, glicerol e ácido acético, insolúvel em solventes orgânicos e incompatível com tanino e formaldeído (Windholz et al., 1983).

Para a gelatina gelificar é necessária apenas uma concentração de $1 \%$ e o resfriamento, porém essa propriedade se perde com a fervura contínua. Dentro da macromolécula, as regiões ricas em determinados aminoácidos proporcionam zonas de união para o estabelecimento da rede tridimensional do gel (Wong, 1995).

Os géis da gelatina são compostos por três cadeias separadas de aminoácidos alinhados e enrolados entre si e essas hélices são mantidas unidas por ligações fracas entre as cadeias de polipeptídeos. Os fatores que influenciam na rigidez da gelatina envolvem a concentração, temperatura, a massa molecular, reagentes adicionados, e pH - entretanto, a influência desses fatores é limitada. A rigidez é aproximadamente proporcional ao quadrado da concentração (Meyes, 1975). A proporcionalidade não é estritamente válida para algumas amostras e para todas as condições.

A temperatura tem um efeito marcante na rigidez, que aumenta rapidamente com o decréscimo da temperatura. Essa relação é linear. A massa molecular tem um efeito direto na rigidez. Por isso, as amostras com média alta de massa molecular formam géis mais rígidos controlados sob condições do 
que aqueles com média baixa de massa molecular. $\mathrm{O}$ efeito do $\mathrm{pH}$ é apenas desprezível em pontos próximos ao ponto isoelétrico da amostra. Assim, uma variedade de géis a uma concentração de $3 \%$ mostrou pequenas mudanças na rigidez em valores de $\mathrm{pH}$ entre 4,6 a 8,2 (Meyes, 1975), enquanto que a uma concentração de $1,5 \%$ a rigidez se manteve constante entre $\mathrm{pH} 4,3$ a 6,7.

Um estudo com gelatina de peixe mostrou uma possivel alternativa para a gelatina proveniente de mamíferos, mas não diretamente substituível devido à baixa resistência do gel. Porém, a mistura da gelatina de peixe e א-carragena resultou em soluções e géis com vários graus de turbidez, dependendo da concentração dos polímeros, do $\mathrm{pH}$, da força iônica e da natureza do sal adicionado (Haug, Draget, Smidsrød, 2004).

A gelatina é um importante biopolímero functional e o seu maior uso em produtos alimentícios é em sobremesas na forma de hidrogéis (Zhou \& Regenstein, 2007). A resistência do gel de uma sobremesa de gelatina depende principalmente das propriedades do gel e da sua concentração. Embora a força do gel seja o critério comercial mais importante para a sobremesa, esse parâmetro não representa todas as propriedades de textura encontradas durante o consumo, para cuja avaliação os métodos devem incluir contato com os dedos, os dentes e a língua sob condições destrutivas e não-destrutivas (Zhou \& Regenstein, 2007).

Estudos usando testes reológicos (Gilsenan \& Ross-Murphy, 2000; Gudmundsson, 2002; Joly-Duhamel et al., 2002; Zhou et al., 2006) forneceram informações úteis nas propriedades dos géis de gelatina, mas essas medidas geralmente não correlacionam com a avaliação sensorial (Bourne, 2002; Foegeding et al., 2003). Por outro lado, testes reológicos de grande deformação correlacionariam melhor com os estudos sensoriais nos sistemas gelificados (Muñoz et al., 1986a, 1986b; Barrangou et al., 2006) e têm sido aplicados para medir texturas de géis de gelatina (Muñoz et al., 1986a, 1986b; Bot et al., 1996; Surówka, 1997).

A gelatina é um ingrediente comum nos alimentos devido à sua versatilidade. Ele pode ser utilizado como agente gelificante, espessante, 
emulsificante (Yang et al. 2007), estabilizante como a pectina. Além disso, ela pode ser usada como clarificante de vinho, cerveja e de compostos fenólicos de sucos (Vardin, Fenercioglu, 2003), para fazer cápsulas de pílulas mais fáceis de engolir e também em cosméticos, pastilhas e pomadas. A produção anual mundial de gelatina correspondente ao ano de 2006 foi de 315.000 toneladas (FIG. 3).

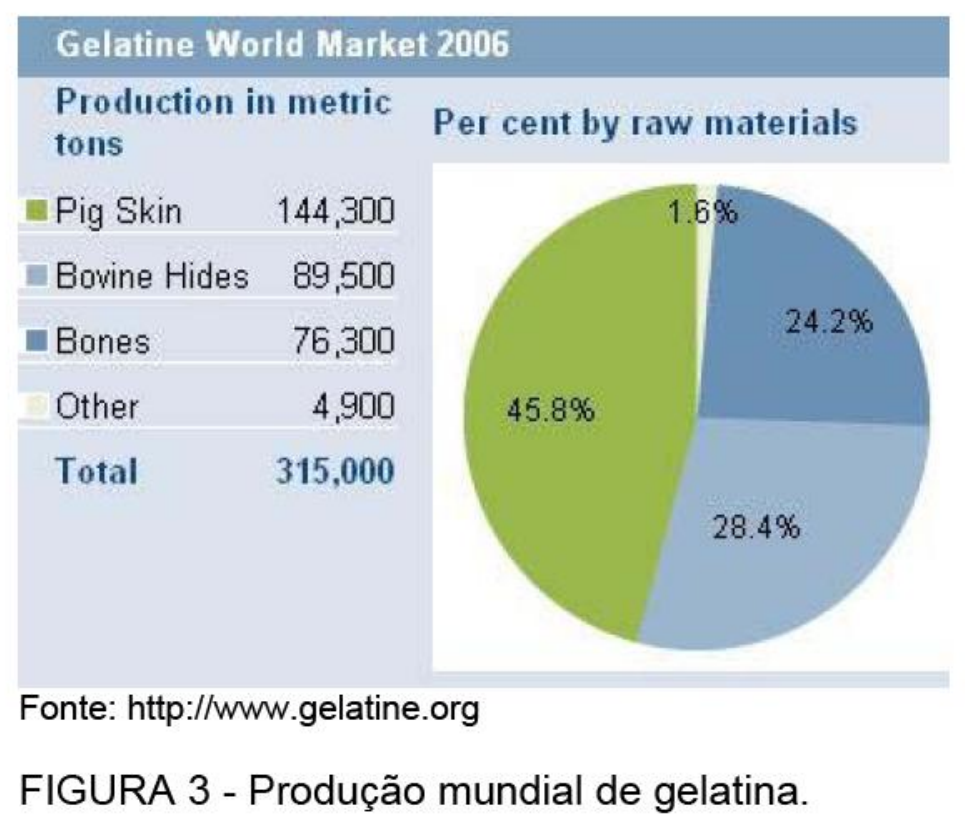

\subsection{Aplicações de Pectina e Gelatina como Biopolímeros Biodegradáveis}

Preocupações com problemas de devastação ambiental causados pelos materiais de embalagens plásticas não-biodegradáveis, bem como a exigência dos consumidores por produtos alimentícios de alta qualidade têm causado um aumento no interesse no desenvolvimento de embalagens de materiais biodegradáveis utilizando biopolímeros naturais renováveis como polissacarídeos e proteínas (Rhim \& Perry, 2007).

Os materiais mais utilizados para embalagem de alimentos são polímeros sintéticos de origem petroquímica por causa de sua disponibilidade, baixo custo e características funcionais. Entretanto, esses materiais são totalmente não biodegradáveis, sendo responsáveis por sérios problemas 
ecológicos. Assim, a tendência atual é a procura pelo desenvolvimento de novos materiais biodegradáveis renováveis provenientes de subprodutos da agricultura, resíduos da indústria de processamento de alimentos e fontes naturais de baixo custo (Alves et al., 2006).

De maneira geral, os biopolímeros são hidrocolóides essenciais para a vida e incluem ácidos polinucléicos (DNA e RNA), polipeptídeos e polissacarídeos. Suas habilidades para construir estruturas altamente ordenadas reversíveis mediadas pelo mecanismo de reconhecimento molecular é essencial para suas funções (Sletmoen et al., 2008).

Os biopolímeros comumente utilizados para produzir filmes para cobertura de alimentos são carboidratos, frequentemente amido ou materiais pécticos e proteínas vegetais e animais (Vermeiren et al., 1999; Alvarez, 2000).

Usualmente, estes biopolímeros precisam melhorar suas propriedades mecânicas e reológicas, bem como os requerimentos de barreira por reestruturação molecular ou pela inclusão de aditivos permitidos para alimentos.

Segundo Gennadios et al. (1997), Gómez-Estaca et al. (2007), Maftoonazad et al. (2007) e Maizura et al. (2007), filmes e coberturas comestíveis podem ser preparados mediante uma variedade de materiais incluindo polissacarídeos, proteínas e lipídios. Extratos de polpa de frutas, os quais contêm pectina, celulose, pigmentos, e outros compostos funcionais também podem ser usados como um novo material formador de filme para produzir filmes e coberturas comestiveis (Park \& Zhao, 2006). Elas são definidas como finas camadas de material comestivel formadas na superfície do alimento, como uma cobertura, ou colocadas (pré-formado) entre compostos de alimentos (Maftoonazad et al., 2007). Essas coberturas podem ser aplicadas diretamente na matéria-prima (Sathivel, 2005; Stuchell \& Krochta, 1995) ou podem ser feitos filmes que serão usados para cobrir a superfície do alimento (Oussalah et al., 2004). Seu propósito é reduzir a desidratação dos alimentos (Vachon et al., 2003), estender a vida de prateleira dos produtos alimentícios e fornecer barreiras contra riscos de contaminação. 
Os filmes comestiveis e coberturas à base de polpa de frutas poderiam fornecer benefícios adicionais ao tradicional material formado de filme comestivel dispondo de aromas de frutas e cores únicas e, assim, atraindo mais aplicações potenciais (Park \& Zhao, 2006).

A gelatina ou a mistura gelatina-chitosana foram utilizados para fazer filmes comestiveis (Gómez-Estaca et al., 2007). A preservação de carnes e outras matérias-primas pela sua cobertura com filmes de gelatina foi proposta por Harvard \& Harmony (1869) e por Morris \& Parker (1895) apud Kester \& Fennema (1986).

A gelatina, à semelhança de outras proteínas comestiveis como glúten de trigo, zeína, gluteína de milho, proteína de soja, de algodão e caseína são utilizadas para a formação de bioplásticos com características semelhantes aos plásticos convencionais sintéticos (Di Giola, L.; Cub, B.; Guilgert, S., 1998) (Guilbert, 2002).

Segundo Antoniewski et al. (2007), gelatina de origem bovina a $20 \%$ utilizada como cobertura aumentou a vida-de-prateleira de carne bovina fresca, lombo suíno e filé de salmão, reduzindo a deterioração da cor das carnes devido à barreira ao oxigênio e alterações na oxidação lipídica não foram vistas.

Em uma solução contendo baixo teor de gelatina e alto teor de silicato de sódio obteve-se um precipitado contendo uma proporção molar fixa de silicone/polímero (Coradin, Bah, Livage, 2004). A microscopia eletrônica de varredura revelou que eles são formados de agregados constituídos de nanopartículas firmemente unidas. Em altos teores de gelatina, o composto formado consiste em partículas de sílica dispersas em uma matriz de biopolímeros. Estudos de expansão indicam que a adição de sílica diminui a estabilidade do gel pela indução da redução da gelatina na solução.

Foi sugerido que a mistura de proteínas com polissacarídeos pode melhorar as propriedades físicas de filmes comestíveis (Coughlan et al., 2004). 


\subsection{Tecnologia das Radiações lonizantes}

\subsubsection{Radiações lonizantes}

Sabe-se que todos os seres vivos estão expostos de várias maneiras às fontes naturais de radiação ionizante, pois estamos rodeados pelos elementos radioativos naturais da crosta terrestre e bombardeados por raios cósmicos. Também recebemos exposição interna de elementos radioativos através da água e alimentos e pelo ar que respiramos. Além disso, temos o carbono-14, potássio-40, rádio-226 no nosso sangue e ossos que também são elementos radioativos (IAEA, 2003). Por outro lado, estamos expostos externamente aos raios $\mathrm{X}$ da prática médica e da odontologia, detectores de fumaça por meio da ionização, relógios de pulso luminosos, entre outros.

A radiação refere-se a um fenômeno físico no qual a energia percorre o espaço ou matéria, tal como alimento. Essa energia pode ser aplicada em um processo de esterilização (Ogbadu, 1979), ou preservação de alimentos. Isto é feito pela morte ou inativação dos microorganismos e insetos que podem contaminar o material (Breitfellner et al., 2002). O tipo de irradiação mais útil para esse propósito é a radiação ionizante. Essa forma de radiação contém energia em níveis suficientes para causar a expulsão de elétrons de seus orbitais, resultando na formação de partículas ionizantes. Exemplos de radiações não-ionizantes são microondas e radiação na região do infravermelho. O nível de energia dessas formas de radiação é inferior àquela capaz de produzir a ionização (Hayes et al., 1995).

Os raios gama, raios $\mathrm{X}$ ou elétrons acelerados, dependendo da fonte de radiação, têm capacidade de expulsar elétrons das ligações químicas, perturbando a estrutura da molécula. O processamento por radiação ionizante nas condições recomendadas pela Comissão do Codex Alimentarium e estabelecidas na legislação brasileira (BRASIL, 2001) não aumenta o nível normal de radioatividade do alimento, independentemente do seu tempo de exposição à radiação ou o quanto é absorvido de uma dose de energia. Quanto 
maior a exposição dos produtos aos raios gama, maior a dose absorvida. No caso de irradiação com feixe de elétrons, quanto mais vagarosamente o produto é movido sob os feixes de elétrons ou raios $\mathrm{X}$, maior será a dose resultante.

Os tipos de radiação que podem induzir a ionização possuem comprimento de onda curto, mas têm milhões de elétrons volts $(\mathrm{MeV})$ de energia, e incluem raios gama e raios $X$. Eles possuem o maior poder de penetração. Os raios gama são produzidos pelos radioisótopos tais como o cobalto-60 e o césio-137 e contêm energia em torno de 1 a $2 \mathrm{MeV}$. Entretanto, os elétrons possuem relativamente uma baixa energia, que podem ser acelerados com o acelerador linear ou em um gerador de Van de Graaff para alcançar níveis de energia de $10 \mathrm{MeV}$ ou mais altos (Hayes et al., 1995). Esses elétrons altamente acelerados (com energia de até $10 \mathrm{MeV}$ ) podem ser utilizados para irradiar alimentos e também ser convertidos em raios $X$ quando colidirem com placas de metais pesados como o tungstênio.

O conceito de dose de radiação é dado pela quantidade de energia absorvida pelo alimento quando passa através do campo de radiação durante o processamento. Pode ser medida utilizando-se uma unidade chamada de "Gray" (Gy). Em trabalhos antigos, a unidade utilizada era o rad (1 Gy $=100$ rads, $1 \mathrm{kGy}=1000 \mathrm{~Gy}$ ). Em termos de relações de energia, um Gy é igual a um joule de energia absorvida por $\mathrm{kg}$ de alimento sendo irradiado. Na TAB.1 é possível visualizar as unidades de dose de radiação e suas conversões.

TABELA 1 - Unidades de dose de radiação e radioatividade

\begin{tabular}{lll}
\hline & Dose absorvida & Radioatividade \\
\hline Unidade & Gray $(\mathrm{Gy})$ & Bequerel $(\mathrm{Bq})$ \\
\hline Definição & $1 \mathrm{~Gy}=1 \mathrm{~J} / \mathrm{kg}$ & $1 \mathrm{~Bq}=1$ desintegração/seg \\
\hline Unidade antiga & Rad & Curie $(\mathrm{Ci})$ \\
\hline \multirow{3}{*}{ Conversão } & $1 \mathrm{rad}=0,01 \mathrm{~Gy}$ & $1 \mathrm{Ci}=3,7 \times 10^{10} \mathrm{~Bq}=37 \mathrm{GBq}$ \\
& $1 \mathrm{krad}=10 \mathrm{~Gy}$ & $1 \mathrm{kCi}=37 \mathrm{TBq}$ \\
& $1 \mathrm{Mrad}=10 \mathrm{kGy}$ & $1 \mathrm{mCi}=37 \mathrm{PBq}$ \\
\hline
\end{tabular}

Fonte - ICGFI, 1999 . 


\subsubsection{Interação da Radiação com Água, Proteínas e Polissacarídeos}

Espécies reativas de oxigênio são formadas quimicamente, enzimaticamente, fotoquimicamente e pela irradiação de alimentos. Elas são formadas também pela decomposição e inter-reação das espécies reativas de oxigênio (Choe \& Min, 2006). O radical hidroxila $(\bullet \mathrm{OH})$ é a espécie mais reativa, seguido do oxigênio singleto. As reações das espécies reativas de oxigênio com alimentos podem produzir componentes indesejáveis, destruir nutrientes essenciais, alterar funcionalidades de proteínas, lipídeos e carboidratos.

A radiólise da água é de particular interesse na irradiação de alimentos. Ela ocorre pela ação dos radicais livres originados da interação da radiação ionizante com as moléculas de água. Segundo Diehl, (1990), os produtos radiolíticos formados pela interação da radiação com as moléculas de água são: $\bullet \mathrm{OH}, \mathrm{e}_{\text {aq, }}^{-} \bullet \mathrm{H}, \mathrm{H}_{2}, \mathrm{H}_{2} \mathrm{O}_{2}, \mathrm{H}_{3} \mathrm{O}^{+}$.

Enquanto $\bullet \mathrm{OH}, \mathrm{e}_{\text {aq }}^{-} \bullet \mathrm{H}$ são espécies transientes muito reativas, o hidrogênio e o peróxido de hidrogênio são os únicos produtos estáveis da radiólise da água. Por causa das reações:

$$
\begin{gathered}
\mathrm{H}_{2} \mathrm{O}_{2}+\mathrm{e}_{\mathrm{aq}}^{-} \rightarrow \bullet \bullet \mathrm{OH}+: \mathrm{OH}^{-} \\
\mathrm{H}_{2}+\bullet \mathrm{OH} \rightarrow \mathrm{H}_{2} \mathrm{O}+\bullet \mathrm{H}^{-}
\end{gathered}
$$

o hidrogênio e o peróxido de hidrogênio são fundamentalmente consumidos. Assim, a produção de ambos é baixa, mesmo quando a dose de radiação aplicada é alta. Por esse motivo é que a água pode ser utilizada como blindagem nas piscinas de estocagem de fontes gama.

A formação de $\mathrm{H}_{2} \mathrm{O}_{2}$, mesmo sendo um agente oxidante, é pouco relevante frente ao poder oxidativo das outras espécies originadas. $\mathrm{O}$ radical -OH é um poderoso agente oxidante (Breitfellner et al., 2002), entanto que o $\mathrm{e}_{\mathrm{aq}}^{-}$é um forte agente redutor. $\mathrm{O} \bullet \mathrm{H}$ é algo menos efetivo como agente redutor. Como todos os alimentos possuem substâncias que podem ser oxidadas ou 
reduzidas, é possível supor que tais reações venham a ocorrer quando os alimentos contendo água forem irradiados.

Quando soluções aquosas são irradiadas, as moléculas do substrato podem ser afetadas diretamente pelos elétrons incidentes (elétrons Compton). Por outro lado, elas podem ser afetadas pela reação com as espécies intermediárias da radiólise da água, efeito indireto da radiação.

Na presença de água, os polissacarídeos sofrem a ação da radiação sobre as moléculas dos monossacarídeos e também quebras das ligações glicolíticas que conectam os monossacarídeos entre si. Os carboidratos são atacados principalmente pelos radicais $\bullet \mathrm{OH}$. Os elétrons solvatados e os $\bullet \mathrm{H}$ têm uma participação secundária. Os radicais $\bullet \mathrm{OH}$ abstraem predominantemente o hidrogênio da ligação $\mathrm{C}-\mathrm{H}$, formando água:<smiles></smiles>

Os radicais resultantes reagem por vários mecanismos:<smiles>C[C+]([C+]C(C)(C)OC(C)C(C)O)OC=O</smiles><smiles>CC(=O)[C@H](C)[13CH2][13C](C)(O)[C@H](C)O</smiles> 
Dependendo da posição molecular da carboxila formada, o produto resultante pode ser um ácido, uma cetona ou um aldeído (Choe \& Min, 2006). Considerando que os radicais $\bullet \mathrm{OH}$ podem abstrair hidrogênios de todos os 6 átomos de $\mathrm{C}$ da glicose, uma grande variedade de produtos de reação pode ser formada. Von Sonntag's (1980) listou 34 produtos radiolíticos da glicose.

No caso de irradiação de proteínas, a discussão dos efeitos da radiação tem como base a química da radiação sobre os aminoácidos. As reações induzidas pelos radicais $\bullet \mathrm{OH}, \mathrm{e}_{\mathrm{aq}}^{-} \bullet \mathrm{H}$ que podem ocorrer são: abstração de $\mathrm{H}$, desaminação redutiva, descarboxilação, dentre outras. Assim, podem ser originados diversos produtos radiolíticos tais como: ácido pirúvico, ácido propiônico, amônia, dióxido de carbono, acetaldeido, etilamina e hidrogênio.

Quando as proteínas são irradiadas na presença de água, todas as reações que são possiveis de ocorrer com aminoácidos são também possiveis com proteínas contendo esses aminoácidos. Nas proteínas existem ao redor de 20 aminoácidos e há três espécies reativas originadas pela radiólise da água $\left(\bullet \mathrm{OH}, \mathrm{e}_{\mathrm{aq}}^{-} \bullet \mathrm{H}\right)$ com as quais irão interagir. Dessa maneira, são possíveis interações muito complexas como resultado da irradiação de proteínas em solução.

\subsubsection{Processamento de Alimentos pela Radiação}

A aplicação da radiação ionizante em produtos alimentícios vem crescendo nos últimos anos (Diehl, 2002). Este tratamento induz modificações nos componentes do alimento que envolvem reações de quebras de ligações químicas que dão origem a novas espécies de menor massa molecular ou pelo contrário, dependendo do produto e das condições de irradiação, pode haver reticulação ou formação de agregados com maior massa molecular. As características do alimento podem ser acompanhadas pela análise de textura (Van Nieuwenhuyzen, W. et al., 2006). 
Uma grande variedade de efeitos benéficos pode ser obtida pelo tratamento do alimento pela irradiação, incluindo aumento da vida de prateleira, destruição de insetos e parasitas, inibição de microrganismos, detardar o amadurecimento de frutas e vegetais e prevenir o brotamento de tubérculos (Diehl, 2002; Satin, 1993; Dogbevi et al., 1999; Lacroix \& Quattara, 2000; Breitfellner et al., 2002; Benkeblia et al., 2004).

O processo de irradiação pode causar uma variedade de modificações, sendo que todas elas tem apresentado alguma utilidade em aplicações industriais. Essas modificações incluem: ligações cruzadas ou reticulação, onde cadeias poliméricas são unidas e ligações de alta massa molecular são formadas (Jeon et al., 2002). Normalmente, as ligações cruzadas trazem uma melhoria das propriedades mecânicas, resistência química, estabilidade térmica e outras propriedades importantes (Bosch, 2005). A radiação também pode induzir a degradação polimérica, provocando a redução da massa molecular do polímero mediante a quebra de cadeias (Choe \& Min, 2006). Com a redução da massa molecular, a propriedade física de escoamento desse polímero aumenta e o tamanho das partículas pode ser reduzido.

A radiação ionizante pode ser aplicada para melhorar a segurança alimentar pela redução ou eliminação de microorganismos patogênicos transmitidos por alimentos (WHO, 1999).

Desde tempos remotos, a humanidade tem buscado meios de preservação de alimentos. Métodos como o armazenamento dos alimentos em baixas temperaturas está entre as técnicas de preservação mais antigas já conhecidas. A pasteurização, o congelamento rápido, todos desenvolvidos para aplicações comerciais têm sido usadas com alto grau de sucesso. Um dos métodos com grande potencial de aproveitamento na tecnologia de preservação de alimento é o uso da radiação ionizante (Hayes et al., 1995). Embora tida como uma nova tecnologia, sua pesquisa remonta-se ao início do século XX, iniciados pelas patentes americanas e britânicas, emitidas em 1905 para $\circ$ uso da radiação ionizante para eliminar bactérias em alimentos (ICGFI, 1999). 
A FAO estima que, cerca de $25 \%$ da produção mundial de alimentos são perdidos, após a colheita, devido à ação de insetos, bactérias e roedores (ICGFI, 1999). A irradiação como técnica de preservação não resolverá todos os problemas de perdas de alimentos pós-colheita, mas pode ser uma importante contribuição para diminuir perdas e reduzir a dependência de pesticidas químicos.

A radiação afeta os alimentos de diferentes formas, dependendo da dose, das condições de irradiação e da composição dos alimentos. A maioria dos efeitos da radiação na qualidade dos alimentos está relacionada à formação de radicais pela ionização do oxigênio, água e moléculas de lipídeos nos alimentos (Choe \& Min, 2006; Hayes et al., 1995). Na TAB.2 são apresentadas as aplicações da irradiação de alimentos.

TABELA 2 - Aplicações da irradiação de alimentos.

\begin{tabular}{|c|c|c|}
\hline Benefício & Dose (kGy) & Produtos \\
\hline \multicolumn{3}{|l|}{ Dose baixa (até 1kGy) } \\
\hline (i) inibição do brotamento & $0,05-0,15$ & $\begin{array}{l}\text { Batatas, cebolas, alho, raiz de } \\
\text { gengibre, inhame. }\end{array}$ \\
\hline $\begin{array}{l}\text { (ii) desinfestação de insetos e } \\
\text { desinfecção de parasitas }\end{array}$ & $0,15-0,5$ & $\begin{array}{l}\text { Cereais e grãos de leguminosas, } \\
\text { frutas frescas e secas, peixe e carne } \\
\text { seca, carne de porco fresca. }\end{array}$ \\
\hline $\begin{array}{l}\text { (iii) Atraso em processos } \\
\text { fisiológicos (por exemplo: } \\
\text { maturação) }\end{array}$ & $0,25-1,0$ & Frutas e legumes frescos. \\
\hline \multicolumn{3}{|l|}{ Dose média (1 - 10 kGy) } \\
\hline $\begin{array}{l}\text { (i) Extensão do tempo de } \\
\text { prateleira }\end{array}$ & $1,0-3,0$ & Peixe fresco, morangos, cogumelos. \\
\hline $\begin{array}{l}\text { (ii) Eliminação de } \\
\text { microorganismos da } \\
\text { deterioração e patogênicos } \\
\end{array}$ & $1,0-7,0$ & $\begin{array}{l}\text { Frutos do mar frescos e congelados, } \\
\text { aves e carnes frescas ou congeladas. }\end{array}$ \\
\hline $\begin{array}{l}\text { (iii) Melhora das propriedades } \\
\text { tecnológicas do alimento }\end{array}$ & $2,0-7,0$ & $\begin{array}{l}\text { Uvas (aumento do rendimento do } \\
\text { suco), legumes desidratados } \\
\text { (redução do tempo de cozimento). }\end{array}$ \\
\hline \multicolumn{3}{|l|}{ Dose alta (10 - $50 \mathrm{kGy})$} \\
\hline $\begin{array}{l}\text { (i) Esterilização industrial (em } \\
\text { combinação com calor } \\
\text { moderado) }\end{array}$ & $30-50$ & $\begin{array}{l}\text { Carnes, aves, frutos do mar, } \\
\text { alimentos preparados, dietas } \\
\text { esterilizadas de hospital. }\end{array}$ \\
\hline $\begin{array}{l}\text { (ii) Descontaminação de certos } \\
\text { aditivos e ingredientes de } \\
\text { alimentos }\end{array}$ & $10-50$ & $\begin{array}{l}\text { Especiarias, preparações de enzimas, } \\
\text { goma natural. }\end{array}$ \\
\hline
\end{tabular}
Fonte - ICGFI, 1999. 
Especiarias estão sendo irradiadas comercialmente, evitando a fumigação, em muitos países incluindo a Argentina, Bélgica, Brasil, Canadá, China, Dinamarca, Finlândia, França, Hungria, Indonésia, Israel, México, Holanda, Noruega, República da Coréia, África do Sul, Reino Unido e EUA.

A irradiação é um tratamento alternativo que tem mostrado grande eficiência na redução de contagem microbiológica de vegetais prontos para consumo (Prakash et al., 2000). Esse tratamento tem sido aprovado pelo Food and Drugs Administration dos EUA para o uso em frutas e vegetais em um nível máximo de 1,0 kGy (IFT, 1983).

A aplicação mais importante desse método de preservação de alimentos talvez seja assegurar a qualidade higiênica (Breitfellner et al., 2002) de alimentos sólidos e semi-sólidos, especialmente os de origem animal, através da inativação de patógenos (Ogbadu, 1979) que possam estar contidos no alimento. Esta aplicação pode ser comparada à pasteurização a frio dos alimentos, adequada para alimentos como aves, carnes e frutos do mar que devem ser comercializados em estado natural.

Irradiação de alimentos é uma tecnologia promissora que pode contribuir para a segurança de abastecimento de alimentos e que oferece algumas vantagens sobre outros métodos de preservação de alimentos. Primeiro, a qualidade dos produtos é pouco afetada em relação a outros tratamentos. Em muitos casos, com a irradiação os produtos estão em uma posição mais desejáveis do que os não irradiados. Segundo, o produto pode ser irradiado depois de embalado, eliminando qualquer tipo de contaminação cruzada que poderia ocorrer. Terceiro, a irradiação oferece um ponto crítico de controle para o consumidor. No caso de falha para alcançar a temperatura interna específica durante o cozimento do produto, a irradiação é uma garantia para o consumidor porquanto as bactérias contaminantes seriam preventivamente eliminadas pela irradiação (Hayes et al., 1995).

Alimentos esterilizados por irradiação, utilizando doses acima de $25 \mathrm{kGy}$, podem ser dados a pacientes com deficiência do sistema imunológico, que requerem dieta estéril (Del Mastro, 1999). Produtos esterilizados por 
irradiação são consumidos por astronautas nos programas espaciais da NASA devido à sua qualidade superior, segurança e variedade, comparados a alimentos tratados por outras técnicas de preservação.

\subsubsection{Legislação de Alimentos Irradiados}

Segundo a legislação brasileira (BRASIL, 2001), com base no Codex Alimentarius $^{7,8}$, poderão ser utilizadas nos alimentos as irradiações ionizantes em geral, cuja energia seja inferior ao limiar das reações nucleares que poderiam induzir radioatividade no material irradiado. Essas radiações são:

- Raios gama de ${ }^{60} \mathrm{Co}\left(\mathrm{T}_{1 / 2}: 5,263\right.$ anos; $\beta_{-}: 0,314 \mathrm{MeV} ; \gamma: 1,173 \mathrm{e}$ $1,332 \mathrm{MeV})$;

- Raios gama de ${ }^{137} \mathrm{Cs}\left(\mathrm{T}_{1 / 2}: 30\right.$ anos; $\beta_{-}: 0,514$ e 1,176 MeV, que decai a $137 \mathrm{mBa}, \mathrm{T}_{1 / 2}: 2,554 \mathrm{~min}$; $\gamma: 0,662 \mathrm{MeV}$ ) que quase não é utilizado (ICGFI, 1999);

- Feixe de elétrons de até $10 \mathrm{MeV}$;

- Raios X de até $5 \mathrm{MeV}$.

Qualquer alimento poderá ser tratado por radiação desde que sejam observadas as seguintes condições: a) A dose mínima absorvida deve ser suficiente para alcançar a finalidade pretendida; b) A dose máxima absorvida deve ser inferior àquela que comprometeria as propriedades funcionais e ou os atributos sensoriais do alimento.

Em relação à segurança de alimentos irradiados, o Comitê Conjunto de Especialistas em Irradiação de Alimentos (JECFI) avaliou os dados disponíveis em 1964, 1969, 1976 e 1980. Em 1980, ele conclui que a irradiação de alimentos até uma dose de $10 \mathrm{kGy}$ não apresenta qualquer risco toxicológico e não é necessário qualquer teste adicional para provar isto. $O$

\footnotetext{
${ }^{7}$ http://www.codexalimentarius.net/download/standards/16/CXS 106 2003e.pdf

${ }^{8}$ http://www.codexalimentarius.net/download/standards/18/CXP 019e.pdf
} 
comitê afirmou ainda que irradiação até $10 \mathrm{kGy}$ "não introduz quaisquer problemas especiais nutricionais ou microbiológicos" nos alimentos. Posteriormente, esse parecer foi feito extensivo a doses ainda superiores. Num relatório da Organização Mundial da Saúde ficou estabelecido que: "Alimentos irradiados de acordo com Boas Práticas de Produção (GMP) são seguros para o consumo e adequados do ponto de vista nutricional" (High Dose Irradiation: Wholesomeness of Food Irradiated with Doses above 10kGy. Technical Report Series 890 WHO, Geneva, 1999).

\subsection{Viscosidade}

\subsubsection{Definição e Medida da Viscosidade}

Há muitas características de um material que podem indicar sua qualidade e comportamento para um determinado objetivo. O conhecimento das características reológicas é de grande valor para predizer seu escoamento, seu comportamento numa operação de imersão ou a facilidade de manuseio, processamento e uso (Streeter, 1974). A medida da viscosidade pode ser uma ferramenta poderosa no desenho do produto, bem como, em aplicações de qualidade e na engenharia fornecendo produtos alimentícios com atributos quantificáveis (Navarro, 1997).

A viscosidade faz parte da reologia e pode ser definida como o estudo da mudança na forma (Dogan et al., 2007) e no fluir da matéria, abrangendo a elasticidade, viscosidade e plasticidade. A viscosidade, por sua vez, é definida como o atrito interno do fluido, causado pela interação entre as moléculas, os quais ocasionam uma resistência no sentido do escoamento do fluido. Esse atrito se torna aparente quando uma camada do fluido é movida em relação à outra.

Um fluido é uma substância que se deforma continuamente quando submetida a uma tensão de cisalhamento, não importando o quanto pequena possa ser essa tensão (Streeter, 1974). E quanto maior o atrito, maior a força 
requerida para ocorrer o movimento, o qual é chamado de deformação. Nos fluidos todas as deformações envolvem algum tipo de escoamento o que torna seus efeitos totalmente irreversíveis, alvo nos casos de fluidos viscoelásticos onde parte da deformação pode ser recuperada (Navarro, 1997).

As propriedades mais importantes nos cálculos de escoamento de fluidos são a viscosidade e a massa específica; elas têm fundamental importância nos escoamentos laminar e turbulento (Streeter, 1974). E a viscosidade é uma propriedade determinante para usos e aplicações dos materiais fluidos. Além de ser uma medida direta da qualidade do fluido em uso, a viscosidade pode fornecer importantes informações sobre mudanças fundamentais em sua estrutura durante um determinado processo, como por exemplo: polimerização, emulsificação e homogeneização (Navarro, 1997).

Sendo uma variável controladora de processo, torna-se imperioso o estudo dos efeitos da temperatura, pressão, composição, massa molecular entre outras quantidades físicas e físico-químicas sobre a viscosidade, para que estas possam ser, por exemplo, monitoradas a partir de medições de viscosidade.

A viscosidade do gás aumenta com a temperatura, pois aumenta os choques entre as moléculas, mas a viscosidade do líquido diminui, pois esse aumento de temperatura enfraquece a interação entre as moléculas. A variação com a temperatura pode ser explicada examinando-se o mecanismo da viscosidade. A resistência de um fluido ao cisalhamento depende da coesão e da velocidade de transferência de quantidade de movimento molecular. A coesão parece ser a causa predominante da viscosidade em um líquido e como a coesão diminui com a temperatura, a viscosidade segue o mesmo comportamento (Streeter, 1974). Com relação à pressão do líquido, a viscosidade permanece constante, considerando um fluido incompressível e no caso dos gases, a viscosidade permanece constante com aumento de pressão para gases ideais; para gases reais a variação é muito pouca e portanto, constante. 
Isaac Newton definiu a viscosidade considerando o modelo representado por duas placas planas paralelas de mesma área $A$, que estão separados por uma distância $d x$. A placa inferior é fixa e uma força $F$ é aplicada na placa superior, a qual exerce uma tensão de cisalhamento F/A na substância. Newton assumiu que a força requerida para manter essa diferença de velocidade era proporcional à diferença de velocidade através do líquido ou gradiente de velocidade (Dziezak, 1991). Para expressar isso, foi escrito:

$$
\frac{F}{A}=\eta \frac{d v}{d x}
$$

onde $\eta$ é uma constante de um dado material, chamada de viscosidade.

O gradiente de velocidade, $\mathrm{dv} / \mathrm{dx}$ é uma medida de velocidade com que as camadas intermediárias escoam entre elas. Isso descreve a deformação do líquido, chamado de taxa de deformação, simbolizado como $\mathrm{S}$ em uma discussão subseqüente, com unidade $\left(\mathrm{s}^{-1}\right)$. O termo F/A indica força por unidade de área requerida para produzir a ação de deformação. Isso pode ser referido como tensão de cisalhamento e será simbolizado por F', com uma unidade de medida de dynas $/ \mathrm{cm}^{2}$.

Usando um termo simplificado, a viscosidade pode ser definida matematicamente pela fórmula:

$$
\eta=\text { viscosidade }=\frac{F^{\prime}}{S}=\frac{\text { tensão de cisalhamento }}{\text { taxa de deformação }}
$$

A unidade fundamental de medida de viscosidade é "poise" (p). Porém a unidade do Sistema Internacional e de designações Métricas é expressa por "pascal-segundos" (Pa.s) ou (mPa.s), sendo que 1 Pa.s é igual a $10 \mathrm{p} ; 1 \mathrm{mPa}$.s é igual a $1 \mathrm{cp}$. 


\subsubsection{Fluidos Newtonianos}

O tipo de comportamento de escoamento que Newton assumiu para todos os fluidos, incompressíveis, foi "Newtoniano". Entretanto, é um dos vários tipos de comportamentos que se pode encontrar. Um fluido newtoniano pode ser representado graficamente na FIG.3. A figura abaixo mostra que a viscosidade do fluido permanece constante com a variação da taxa de deformação (Dziezak, 1991).

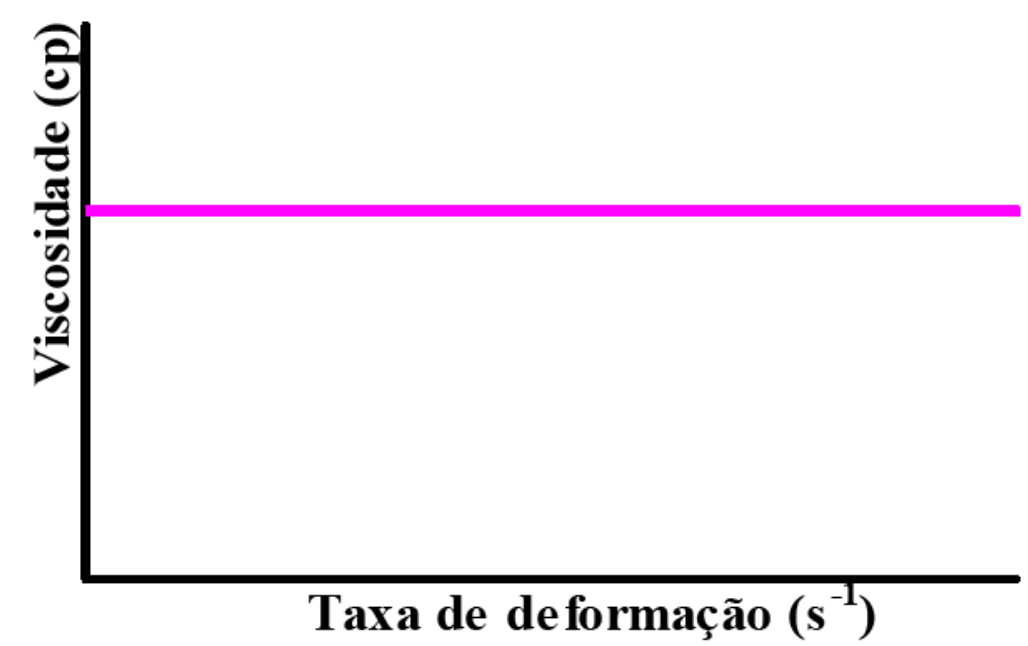

FIGURA 4 - Exemplo de fluido newtoniano.

\subsubsection{Fluidos Não-Newtonianos}

O fluido não-newtoniano foi definido, de modo geral, como o que apresenta a relação F'/S que não é constante, ou seja, quando a taxa de deformação é variada, tensão de cisalhamento não varia na mesma proporção (Dziezak, 1991). A viscosidade desses fluidos vai variar de acordo com a taxa de deformação. O escoamento não-newtoniano é provavelmente uma questão mecânica. Como os objetos assimétricos passam entre eles, e como ocorre durante o escoamento, seu tamanho, forma e coesividade vão determinar o quanto de força é necessário para movê-los.

Há uma variedade de comportamento de escoamento de fluidos não-newtonianos caracterizados pelo modo como a viscosidade do fluido varia 
em relação à taxa de deformação. Os tipos de fluidos não-newtonianos mais comuns são: o pseudoplástico, que exibe um decréscimo na viscosidade com o aumento da taxa de deformação, como mostrado na FIG. 4; dilatante, onde a viscosidade aumenta com o aumento da taxa de deformação; e o plástico, que se comporta como um sólido sob condições estáticas.

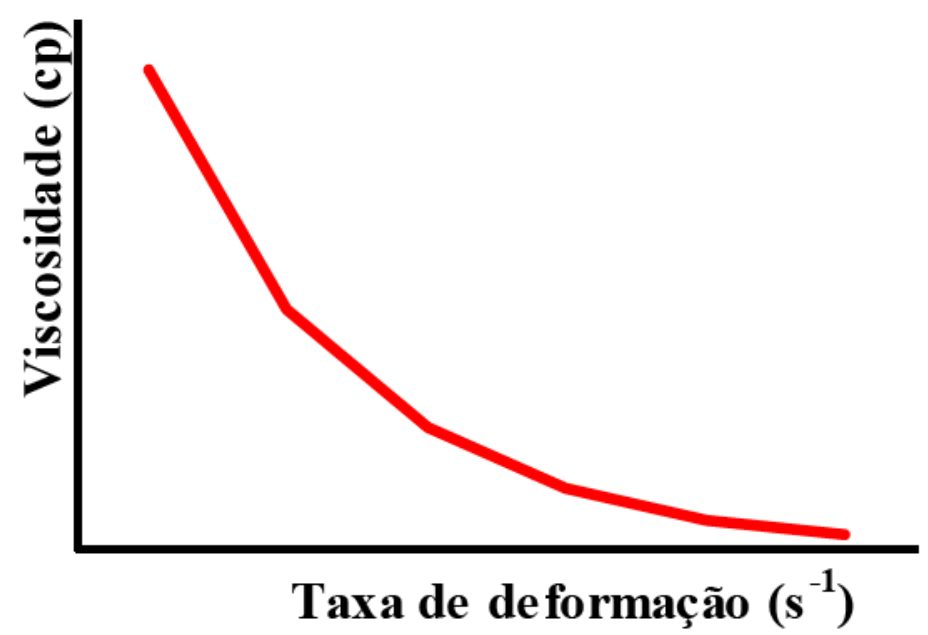

FIGURA 5 - Exemplo de fluido não-newtoniano pseudoplástico. 


\section{MATERIAL E MÉTODOS}

\subsection{Material}

A gelatina bovina, obtida pela hidrólise ácida do colágeno, foi cedida pela GELITA do Brasil Ltda (240Bloom/6mesh - lote: LF21658 05). A amostra de pectina de alto teor de metoxilas (ATM) foi cedida pela CP Kelco do Brasil S/A - Pectina GENU® tipo B rapid set-Z (lote: L54013) e da pectina de baixo teor de metoxilas (BTM) foi cedida pela Plury Química Ltda - Pectina Cítrica GENU BTM Tipo 8002 (lote: L42056). O cloreto de cálcio di-hidratado $\left(\mathrm{CaCl}_{2}\right)$ foi cedido pela Indústria Química River Ltda.

\subsection{Métodos}

\subsubsection{Preparação das Amostras}

Foram feitos ensaios com a gelatina a $0,5 \%$, pectina ATM $1 \%$, pectina BTM 1\%, mistura de pectina ATM e gelatina, na mesma proporção ( $50 \%$ de cada) a 1 e $2 \%$ (p/v) dissolvidas em $300 \mathrm{~mL}$ de água destilada, em um banho a $60^{\circ} \mathrm{C}$, visando conhecer o comportamento das soluções obtidas e géis formados em relação a sua viscosidade, como é mostrado na FIG. 5. A solução de $\mathrm{CaCl}_{2}$ 0,05\% e 0,075\% foi obtida pesando-se a amostra e adicionando-a em $100 \mathrm{~mL}$ de água destilada. Essa solução foi utilizada para dissolver a pectina BTM em um banho a $60^{\circ} \mathrm{C}$. Após a dissolução total, as amostras foram distribuídas em béqueres de $50 \mathrm{~mL}$, completando o seu volume igualmente para todas as doses estudadas, a 1, 3, 5, 10 e $15 \mathrm{kGy}$ e para o controle. Elas 
foram irradiadas em temperatura ambiente (em torno de $25^{\circ} \mathrm{C}$ ) e logo em seguida foram realizadas as medidas de viscosidade (FIG. 6).
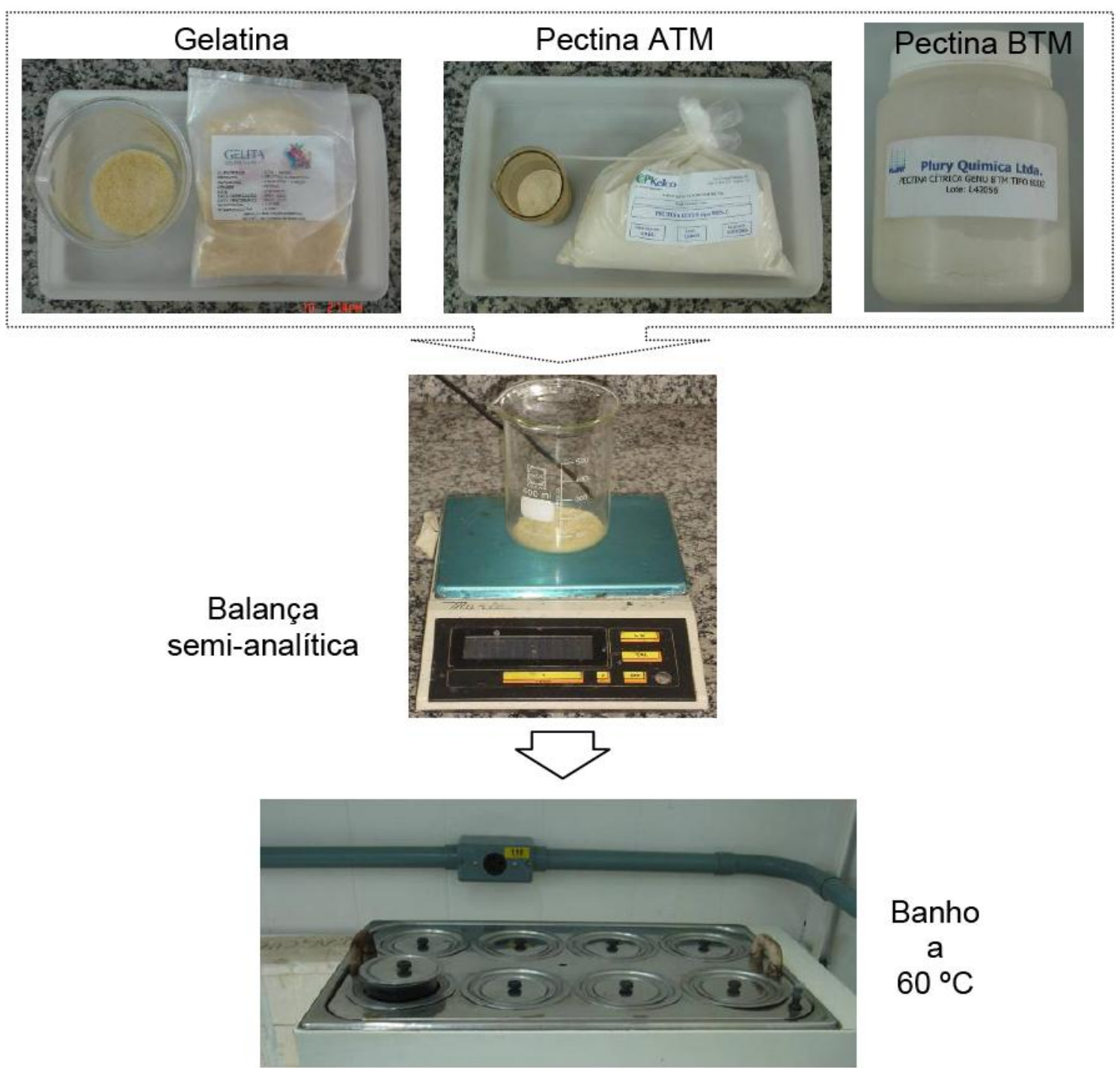

Banho

$60^{\circ} \mathrm{C}$

Distribuição das amostras no irradiador

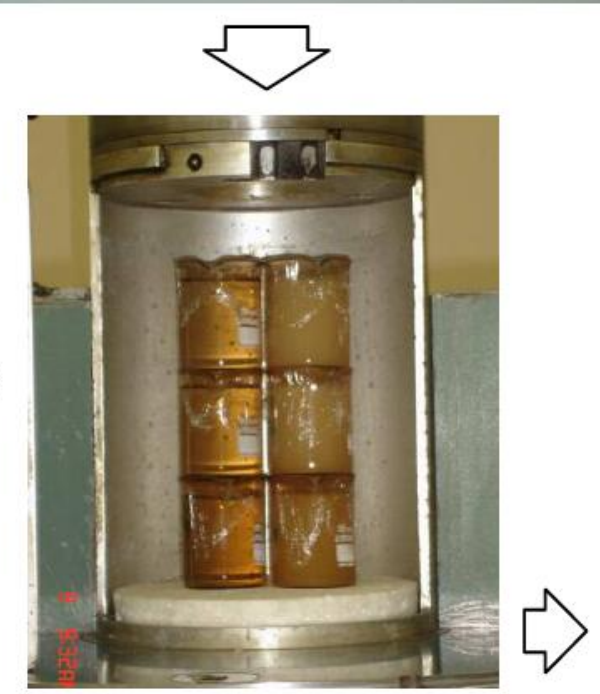

FIGURA 6 - Etapas da preparação de amostra até a irradiação. 

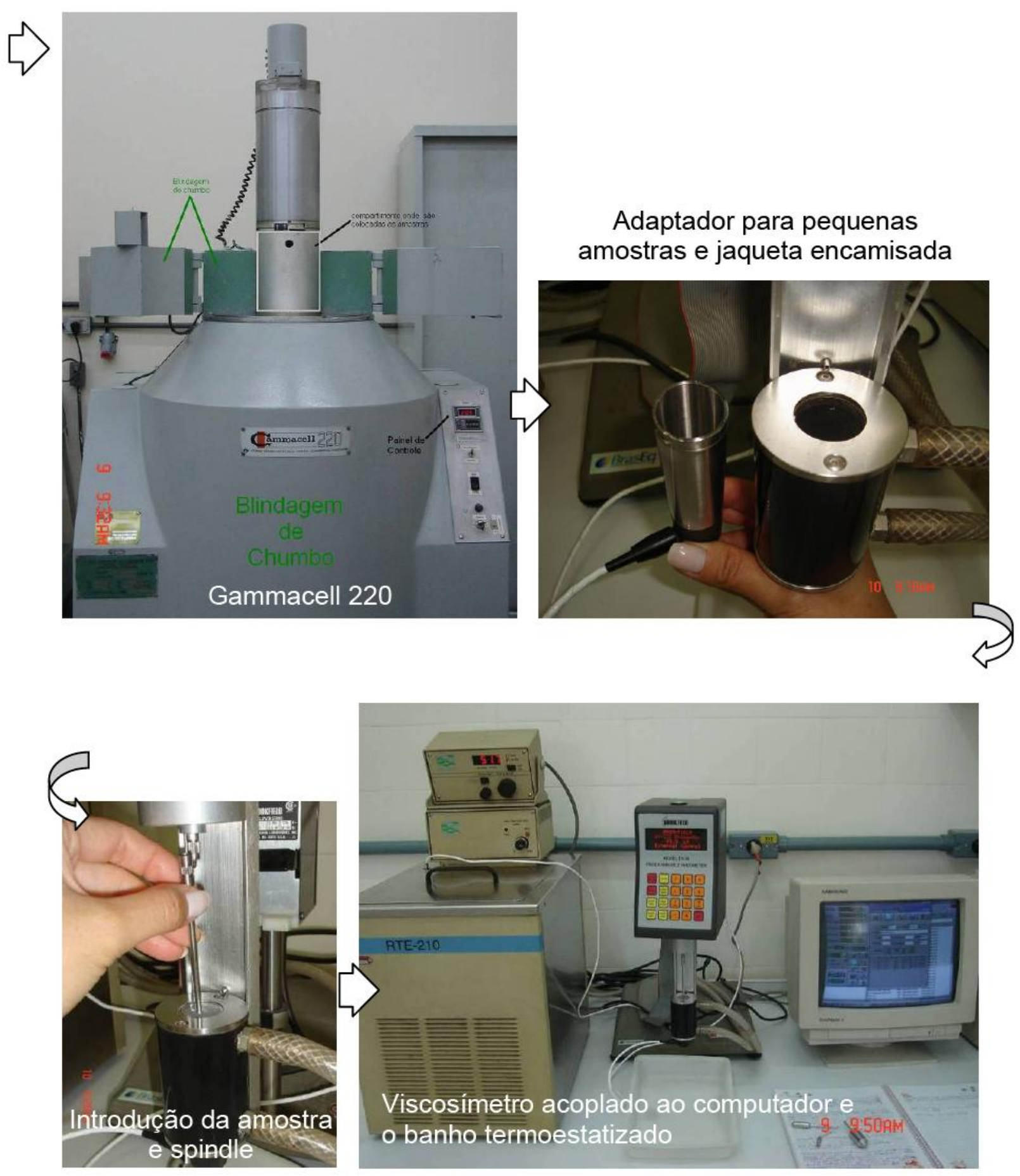

FIGURA 7 - Etapas da análise de viscosidade mediante o uso do viscosímetro Brookfield.

\subsubsection{Irradiação}

As soluções das amostras foram irradiadas em recipientes de vidro, em fonte de ${ }^{60}$ Co Gammacell 220 da AECL (FIG. 4) a 1, 3, 5, 10 e 15 kGy e 
taxa de dose em torno de $2 \mathrm{kGy} / \mathrm{h}$. As doses foram escolhidas dentro do âmbito de doses aplicadas em alimentos, isto é, doses baixas, até $1 \mathrm{kGy}$, médias, até $10 \mathrm{kGy}$ e altas, acima de $10 \mathrm{kGy}$.

\subsubsection{Viscosimetria}

As medidas viscosimétricas foram realizadas a 50,60 e $70^{\circ} \mathrm{C}$ utilizando o viscosímetro de cilindros concêntricos Brookfield (FIG. 6), modelo LVDV-III, com adaptador de pequenas amostras (SSA) e o "spindle" ou haste SC4-14, SC4-18 ou SC4-34, dependendo da viscosidade do fluido, com banho termostatizado Neslab modelo RTE-210, precisão $\pm 0,1^{\circ} \mathrm{C}$. As diluições dos hidrocolóides a serem irradiados foram preparadas mediante aquecimento até dissolução. O viscosímetro acoplado a um software Rheocalc VI.1, forneceu para cada valor de velocidade de rotação do spindle, a viscosidade aparente, a força e a taxa de cisalhamento para cada valor da temperatura. A irradiação das soluções foi realizada imediatamente após o preparo das soluções e a leitura da viscosidade logo após a irradiação.

\subsubsection{Análise de Textura}

As medidas de compressão foram realizadas utilizando texturômetro Stable Micro Systems TA-XT2 com capacidade de compressão de $25 \mathrm{~kg}$. O acessório utilizado foi probe cilíndrico de aço inox, de $35 \mathrm{~mm}$ de diâmetro (P/35) para todas as amostras. As amostras foram comprimidas a uma velocidade de $1 \mathrm{~mm} / \mathrm{s}$ geralmente até $6 \mathrm{~mm}$ de compressão.

A fonte de radiação de Co-60 utilizada, bem como o viscosímetro Brooksfield e o texturômetro Stable Micro Systems encontram-se localizados no Centro de Tecnologia das Radiações, CTR-IPEN-CNEN/SP. 


\subsubsection{Análise Estatística}

Foi realizada análise descritiva unidimensional (03:010*) e multidimensional $\left(03: 020^{*}\right)$. Entre parênteses encontra-se a classificação: Statistical Theory \& Methods Abstract (ISI), utilizando-se variados programas de estatística para explicar a variabilidade de dados e modelos propostos por esses compostos com o auxílio de Heleno Bolfarini, Denis Guilherme Alberghini \& Rafel Leite Neves Roza do Instituto de Matemática e Estatística da Universidade de São Paulo. Médias e desvios padrões foram realizados pelo programa Excel da Microsoft (versão 10.0).

* Classificação: Statistical Theory \& Methods Abstract (ISI) 


\section{RESULTADOS E DISCUSSÃO}

No presente trabalho foi feito um estudo da sensibilidade à radiação de dois tipos de aditivos alimentares, pectina, com dois diferentes graus de metoxilação, e gelatina, bem como, a mistura de ambas, por meio de medidas de viscosidade.

Todas as amostras apresentaram-se como fluidos não-newtonianos, pois sua viscosidade variou com a tensão de cisalhamento, torque e velocidade de rotação, conforme dados apresentados nas FIG. 8 - 11. A FIG. 8 mostra da distribuição dos dados de viscosidade, tensão de cisalhamento e torque de todas as amostras utilizadas. A FIG. 9 descreve a relação da viscosidade e a tensão de cisalhamento de todas as amostras ensaiadas. A FIG. 10 mostra a relação da tensão de cisalhamento em função da \% do torque de todos os compostos e na FIG. 11 está descrita a relação da viscosidade de todas as amostras e o percentual do torque.
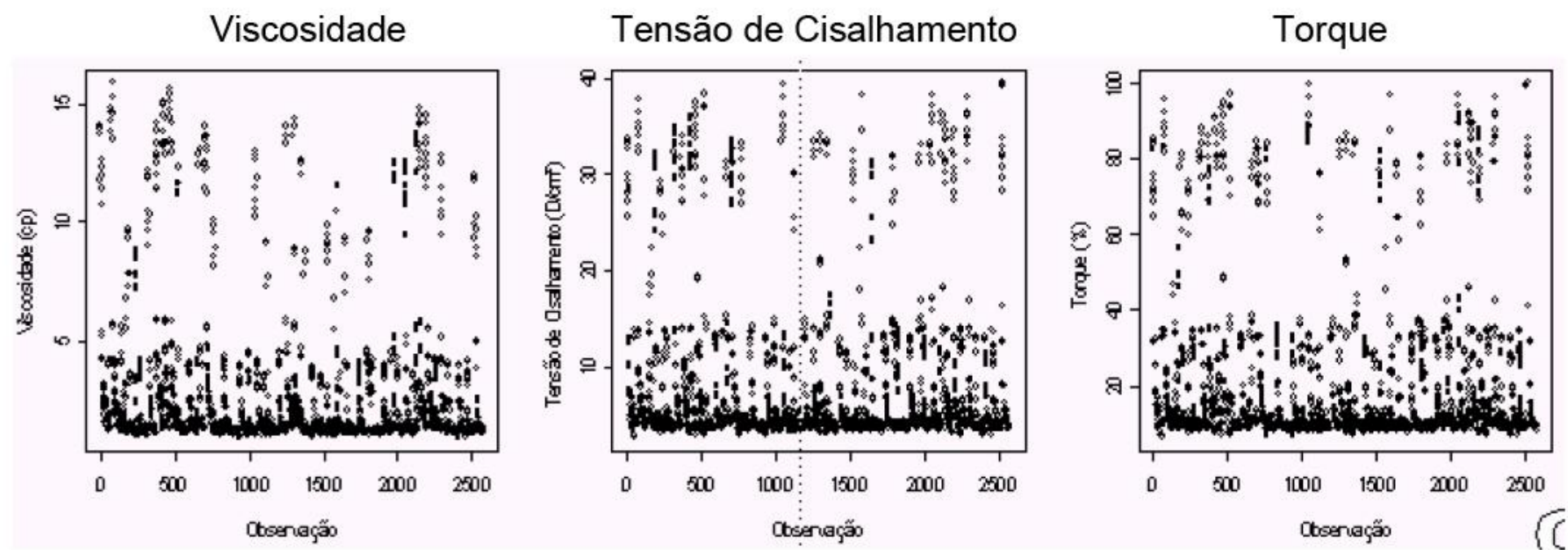

FIGURA 8 - Distribuição dos dados de viscosidade, tensão de cisalhamento e torque de todas as amostras estudadas. 


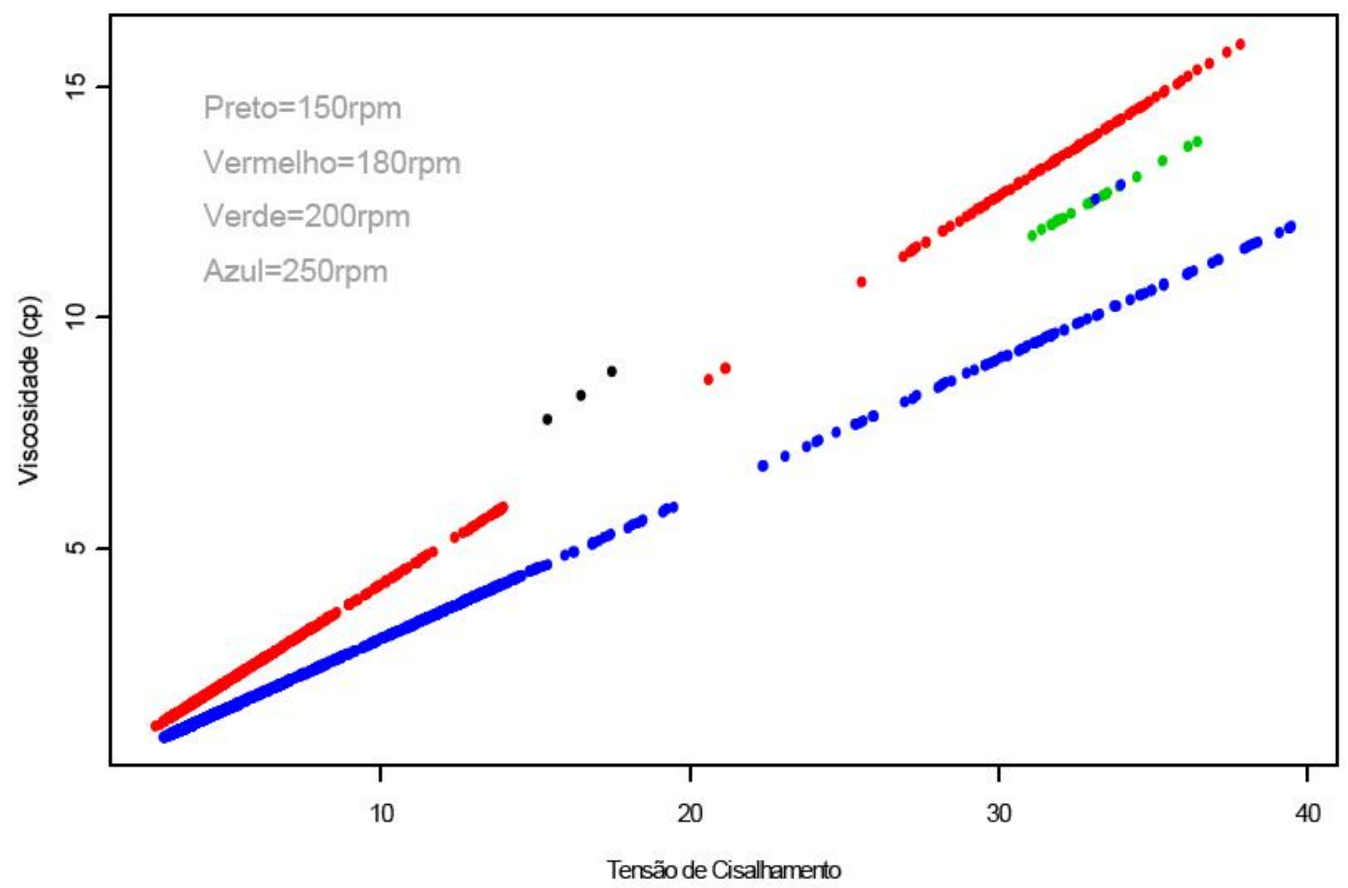

FIGURA 9 - Relação entre a viscosidade e tensão de cisalhamento de todas as amostras.

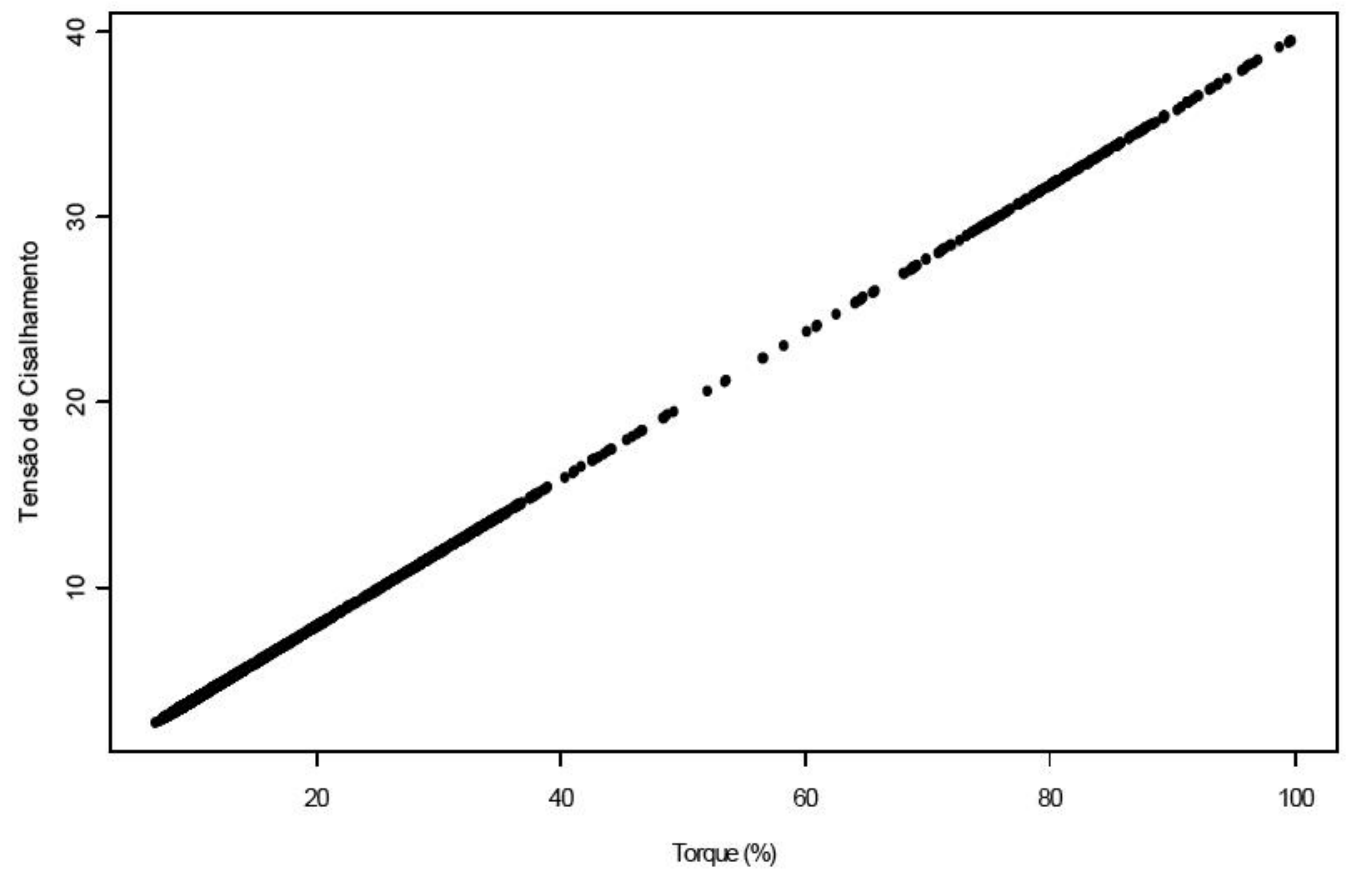

FIGURA 10 - Tensão de cisalhamento em função do torque (\%) de todas as amostras. 


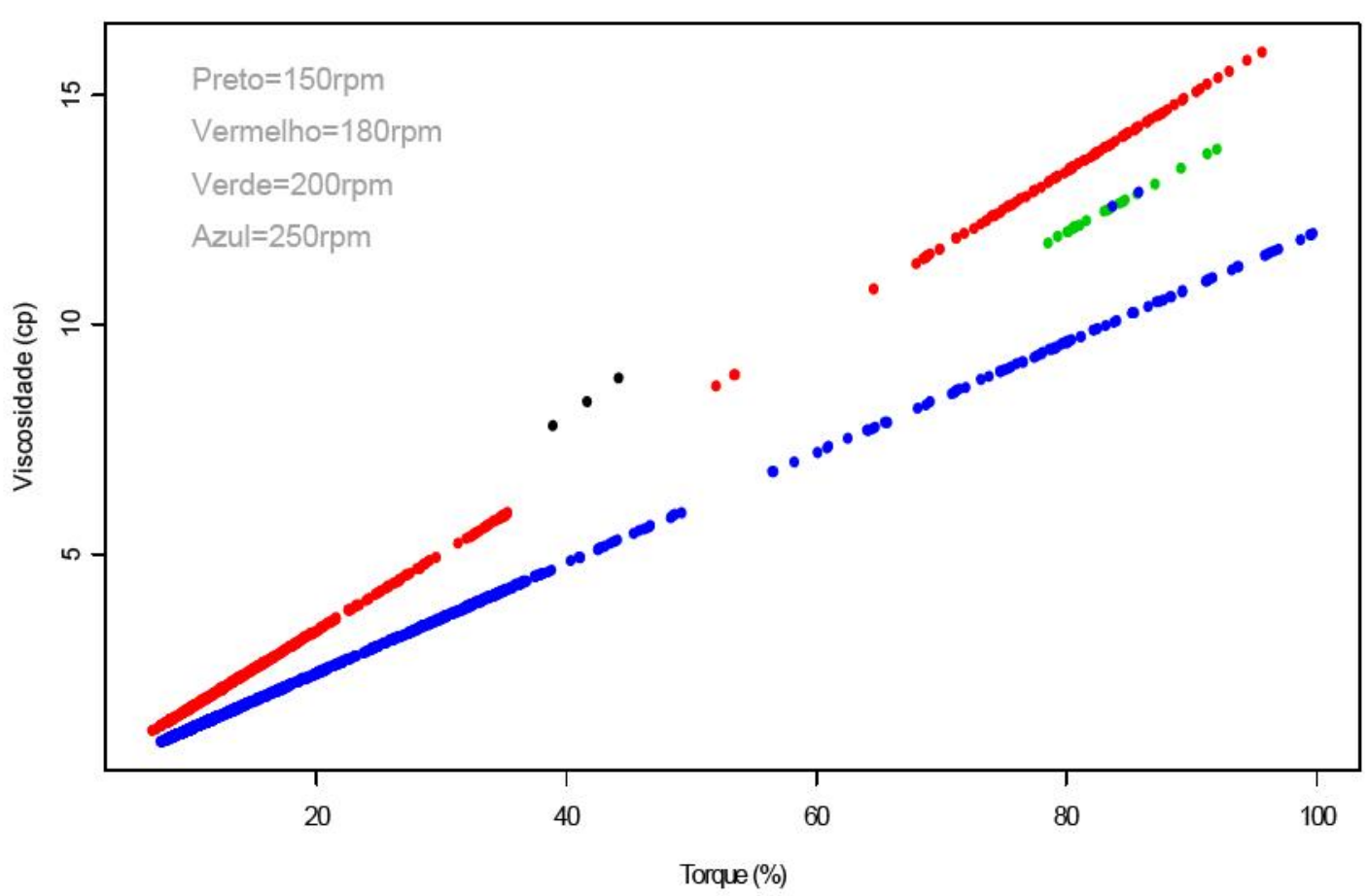

FIGURA 11 - Relação da viscosidade de todos os compostos e o torque (\%).

Nas FIG. 12, 13 e 14 é mostrado o efeito da radiação ionizante na viscosidade de diversas soluções da gelatina: $0,5 \%, 1 \%$ e $2 \%$, medida a $50^{\circ} \mathrm{C}$, $60^{\circ} \mathrm{C}$ e $70^{\circ} \mathrm{C}$. Há pouca influência da ação da radiação sobre a viscosidade deste hidrogel protéico mesmo para os valores mais altos de dose aplicada de $15 \mathrm{kGy}$, sugerindo baixa radiossensibilidade, como descrito anteriormente (Vieira \& Mastro, 2002). Contudo, os dados sugerem uma leve diminuição da viscosidade com o aumento da dose de maneira geral. Foi possível perceber, entretanto, um aumento no valor da viscosidade nas amostras irradiadas a 3kGy. Al-Assaf, Phillips \& Williams (2006) ponderam que mudanças nas propriedades físicas como a viscosidade refletem mudanças moleculares. Assim, pode-se supor que a formação de agregados moleculares ou reticulação seriam os responsáveis por esse aumento da viscosidade. 

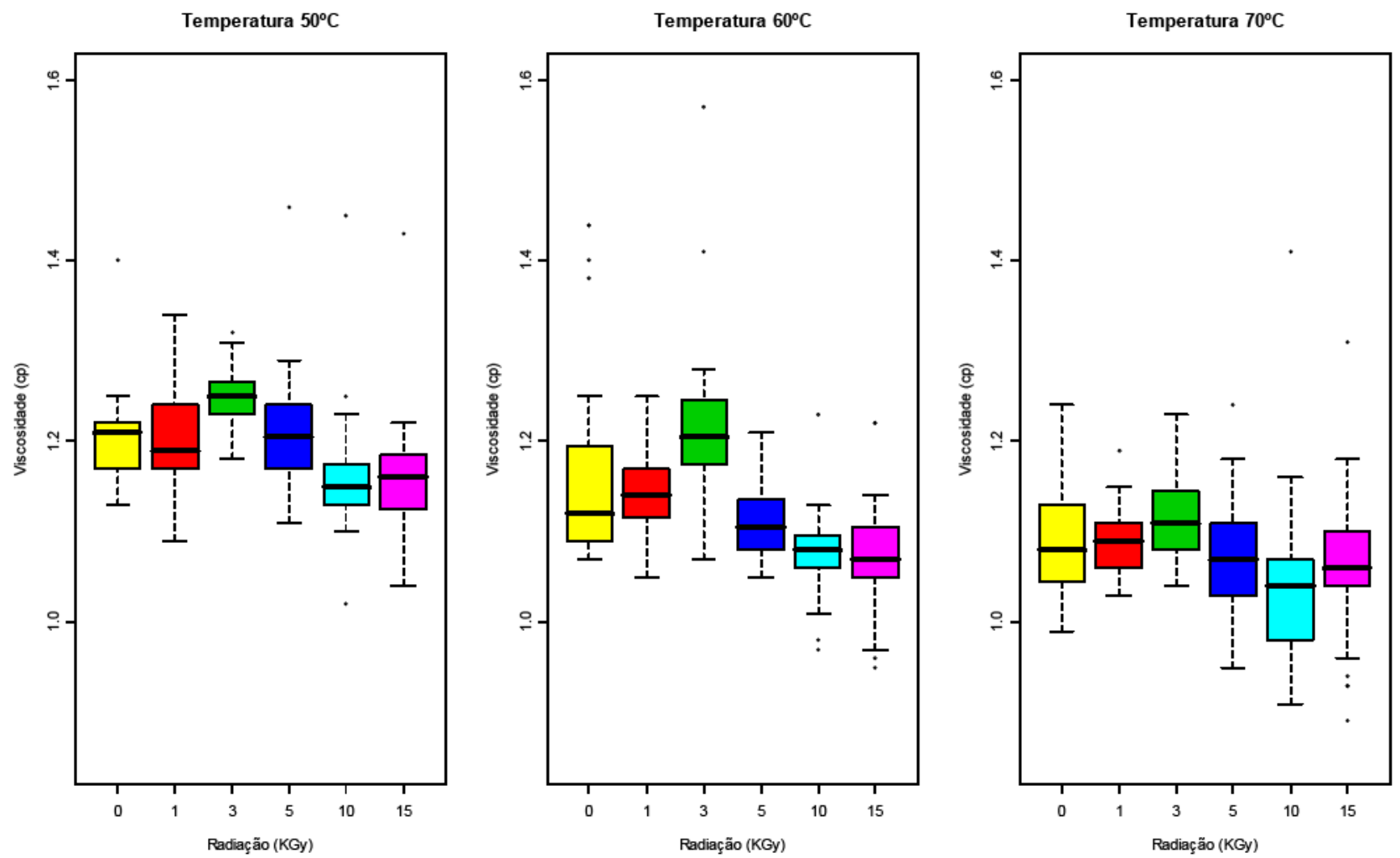

FIGURA 12 - Relação da viscosidade com a dose de radiação de soluções de gelatina $0,5 \%, 250 \mathrm{rpm}$ a 50,60 e $70{ }^{\circ} \mathrm{C}$.
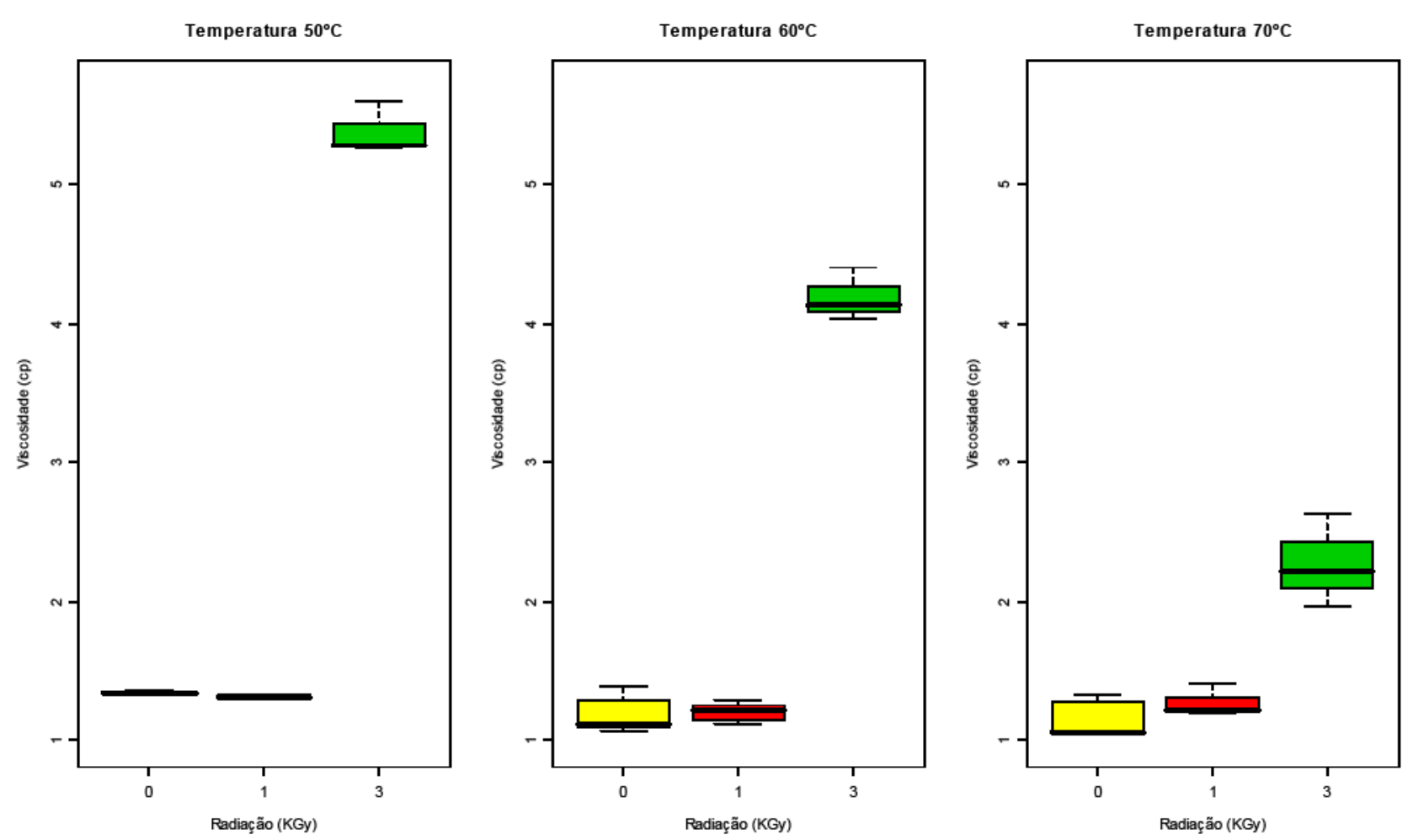

FIGURA 13 - Relação da viscosidade com a dose de radiação de soluções de gelatina $1 \%, 250 \mathrm{rpm}$ a 50,60 e $70^{\circ} \mathrm{C}$. 

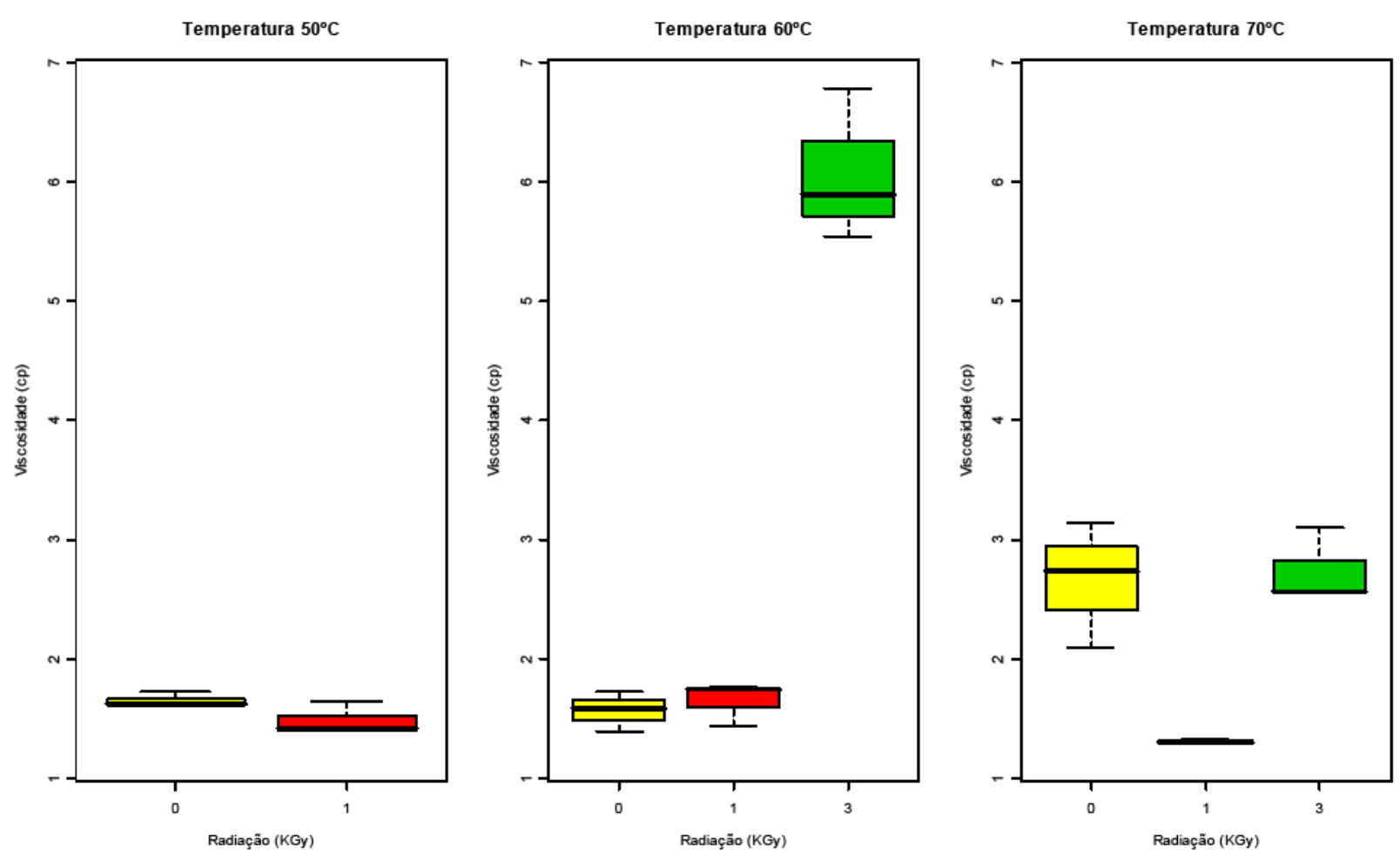

FIGURA 14 - Viscosidade vs dose da gelatina $2 \%, 250 \mathrm{rpm}$ a 50,60 e $70^{\circ} \mathrm{C}$.

Ressouany et al. (1998) reportaram que a irradiação gama aumentou significativamente as propriedades mecânicas de filmes protéicos pela indução de ligações cruzadas entre cadeias de proteínas. O tratamento com radiação ionizante causou modificações nas propriedades hidrodinâmicas de cápsulas de gelatina (Cilurzo et al., 2005). Mas, como salientou Bohidar (1998), apenas mudanças na massa molecular não poderiam afetar a interação hidrodinâmica entre o solvente e o polipeptídeo. A leitura de viscosidade das amostras de gelatina irradiadas acima de $3 \mathrm{kGy}$ não foi realizada, pois, as amostras não dissolveram no banho a $60^{\circ} \mathrm{C}$ nem em banho fervente, comprovando sua irreversibilidade.

As características do alimento podem ser acompanhadas pela análise de textura (Van Nieuwenhuyzen et al., 2006). Apenas para amostras de gelatina foram feitas algumas medidas de textura. Pela FIG. 15 é possível observar que a ruptura do gel a compressão ocorre em diferentes forças e 
distâncias. Segundo Inamura \& Mastro (2007), a amostra de gelatina irradiada a $5 \mathrm{kGy}$ obteve a maior resistência à ruptura, indicando a reticulação do gel. Já as amostras a 10 e 15 kGy, embora possa-se observar uma força de ruptura alta, o rompimento ocorreu no início da compressão, evidenciando géis quebradiços. Assim, pode-se sugerir que a irreversibilidade das amostras de gelatina irradiadas acima de $3 \mathrm{kG}$ y seja causada pela irradiação. Analogamente, Jo et al. (2005) \& Lee et al. (2005) observaram que a porcentagem de elongação de filmes a base de pectina e filmes de glúten também diminuíram com o aumento da dose de radiação.

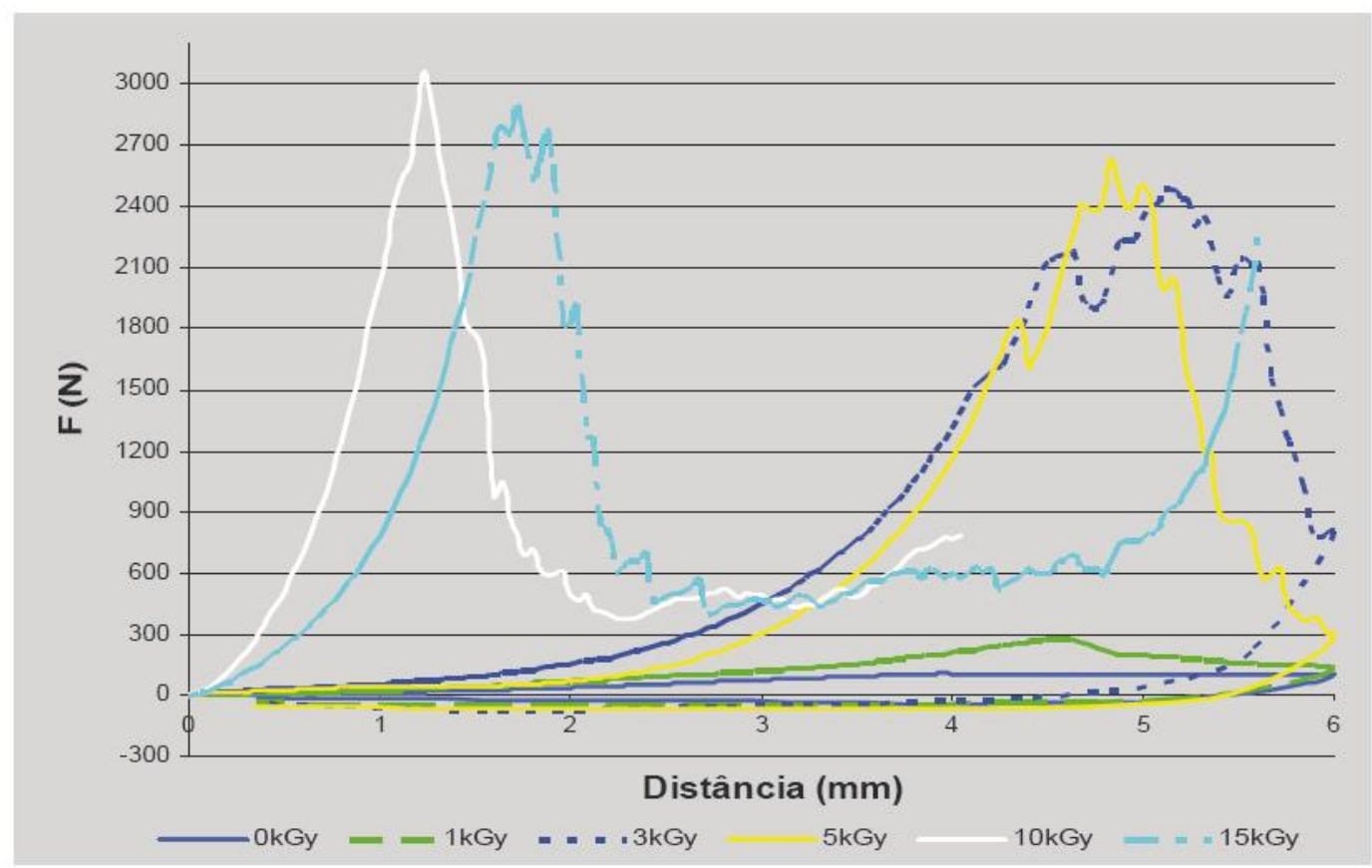

FIGURA 15 - Típico perfil de força-distância de gelatina a $1 \%$ em diferentes doses pela análise de textura.

De acordo com Cieśla et al. (2006), modificações na conformação da proteína induzidas pela radiação podem resultar na formação de géis e filmes melhor estruturados com aperfeiçoamento de suas propriedades funcionais. Segundo Salmoral et al. (2000), que trabalhou na produção de filmes a partir de proteína vegetal, a radiação gama é útil na reticulação de proteínas, o que poderia significar o aumento da resistência à tensão do produto. 
Aumentando a dose de radiação, a fração de gel de gelatina aumentou e a degradação enzimática diminuiu, segundo Terao et al., (2003). Esses autores mostraram que o grau de ligações cruzadas dos hidrogéis de gelatina irradiados aumentara com o aumento da dose de radiação e o decréscimo da concentração. Esses autores sugeriram que a as ligações cruzadas ocorreriam em volta dos pontos de ligações cruzadas físicos ou nas múltiplas hélices da estrutura do gel de gelatina. A formação de ligações cruzadas ou reticulação pode também ocorrer por meio de tratamentos físicos, químicos e enzimáticos (Vacho et al., 2003; Miller et al., 1997; Ghoparde et al., 1995; Li \& Chen, 1999).

Na FIG. 16 é possível observar os efeitos da radiação na viscosidade de soluções de pectina ATM $1 \%$ e pectina BTM $1 \%$ respectivamente, a $50^{\circ} \mathrm{C}, 60^{\circ} \mathrm{C}$ e $70^{\circ} \mathrm{C}$. Neste caso há uma queda brusca de viscosidade já para os valores de $1 \mathrm{kGy}$, evidenciando uma grande radiossensibilidade deste polissacarídeo. De acordo com Dogan et al. (2007), embora o aumento da dose de radiação geralmente cause a diminuição da viscosidade aparente das soluções de hidrocolóides, a magnitude do efeito da radiação na viscosidade aparente é diverso para diferentes hidrocolóides. Segundo esses autores, a exposição à radiação pode produzir alterações nas propriedades químicas dos alimentos, com mudanças nas características de viscosidade e consistência. Aliste et al. (2000) verificaram também que a irradiação causa diminuição da viscosidade de polissacarídeos, provavelmente pela despolimerização induzida por quebra de ligações glicosídicas, resultando em moléculas menores que originariam hidrocolóides com menor consistência.

Segundo Zegota (1999), que também estudou a ação da radiação sobre a pectina, as macromoléculas de pectina foram consideravelmente afetadas pela irradiação e a massa molecular média diminuiu rapidamente com o aumento da dose de irradiação. Fragmentos de baixa massa molecular de ácidos poligalacturônicos, pectinas e alginatos mostraram uma redução no grau de polimerização sobre a exposição crescente de doses de gama irradiação (Wahba, Tallman, Massey, 1998). 
De acordo com Yu \& Wang (2007), valores de umidade de equilíbrio do trigo diminuíram com o aumento da dose de radiação gama durante a adsorção e desorção devido a alterações na habilidade de ligação com a água e nos grânulos de amido do trigo.

Para os polímeros de pectina estudados, a quebra de cadeias parece exercer importante papel na drástica queda de viscosidade. A pectina ATM apresentou inicialmente valores mais altos de viscosidade e a radiação induziu um decréscimo acentuado, como é mostrado na FIG 16. Para a pectina BTM, os valores de viscosidade foram mais baixos inicialmente e também diminuíram drasticamente com o aumento da dose de radiação. Skinner \& Kertesz (1960) já tinham documentado a grande radiossensibilidade de certo tipo de pectina por meio de estudo espectrofométrico.

De acordo com Wahba \& Massey (1963), a pectina é essencialmente uma molécula poliônica linear sensível à quebra oxidativa e hidrolítica pela radiação e meios químicos. O efeito da radiação induziu quebra de cadeias nas moléculas de pectina, fenômeno evidenciado em virtude da redução da viscosidade das soluções de pectina irradiadas, embora esse decréscimo tenha seguido diversos padrões, dependendo do grau de metoxilação dos grupos carboxilas da molécula.

Outras evidências estabelecem que os polissacarídeos sejam degradados pela radiação ionizante, e que polímeros naturais que consistem de resíduos de ácidos urônicos (ácido hialurônico, ácido algínico, ácido poligalacturônico) são muito susceptíveis às quebras glicosídicas induzidas por radicais livres (Akhlaq et al., 1990; Deeble et al., 1990; Myint et al., 1987).

O efeito da radiação em polímeros normalmente depende das espécies moleculares, sua configuração e outras características e por isso esses efeitos oferecem um rico campo de pesquisas para se dedicar (Inokuti, 2005). Nas FIG. 17, 18 e 19 são mostrados os resultados referentes à mistura de soluções de gelatina $50 \%$ e pectina $50 \%$ a uma concentração total de $1 \%$ e $2 \%$, mostrando comportamento semelhante à pectina $100 \%$, seja pectina ATM ou BTM. 


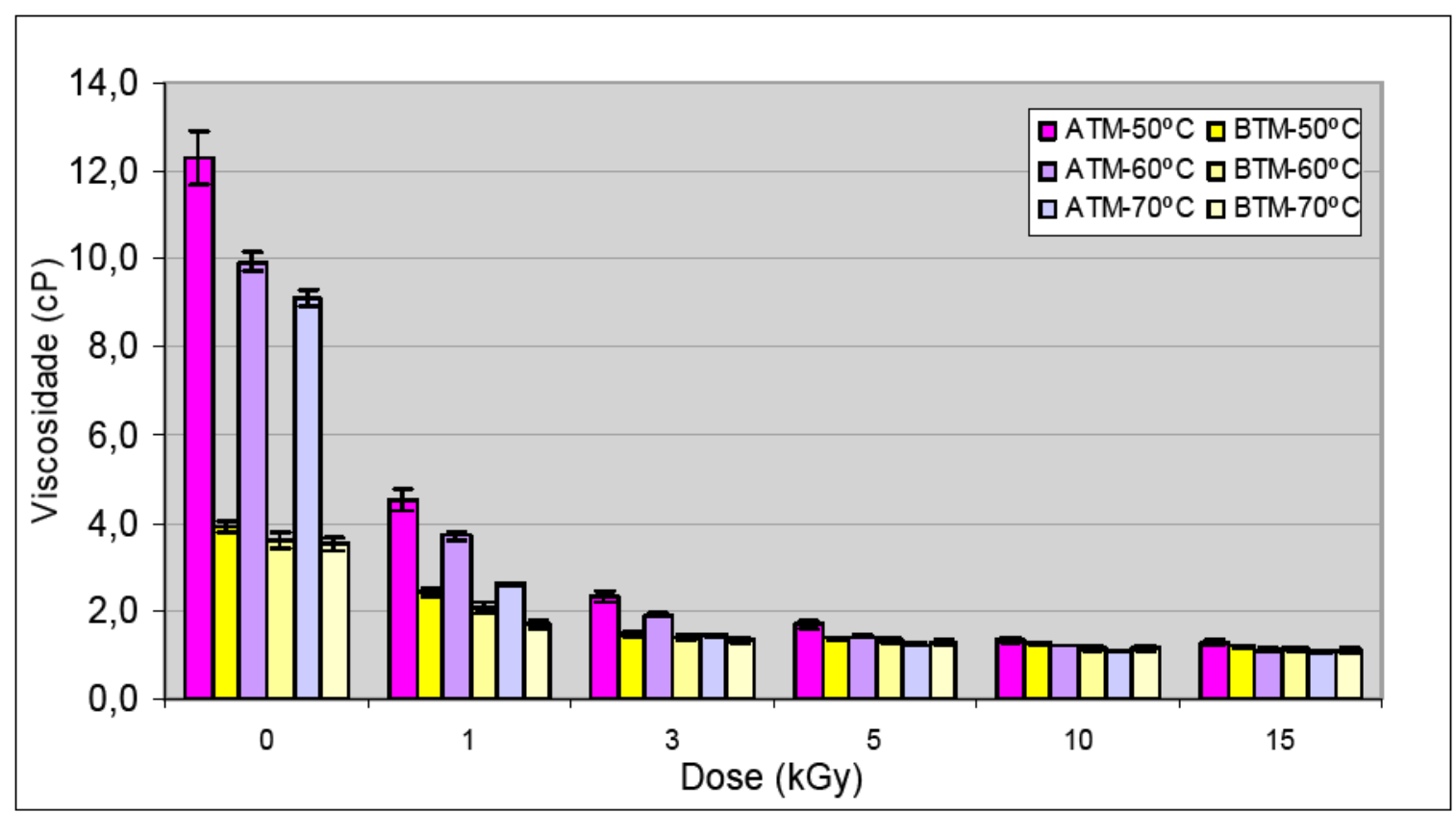

FIGURA 16 - Viscosidade vs dose das pectinas ATM e BTM a 1\%, $250 \mathrm{rpm}$ a 50,60 e $70^{\circ} \mathrm{C}$.

$\mathrm{Na}$ TAB. 3 estão os valores de pH de amostras do presente estudo. É possível observar que irradiação ionizante influencia muito pouco $\circ \mathrm{pH}$ das amostras. E pode-se observar que, mesmo fixando a concentração de pectina e variando a concentração de gelatina, o pH sofre influência do $\mathrm{pH}$ da pectina, enfatizando sua predominância sobre a gelatina.

TABELA 3 - Concentração das amostras e os respectivos valores de $\mathrm{pH}$ das amostras não-irradiadas e irradiadas a $5 \mathrm{kGy}$.

\begin{tabular}{cc}
\hline Amostra/Concentração & $\mathrm{pH}$ \\
\hline $\mathrm{P} 1 \%$ & $3,47^{*}$ \\
$\mathrm{M}(\mathrm{P} 1 \% \mathrm{G} 0,5 \%)$ & $3,80^{*}$ \\
$\mathrm{M}(\mathrm{P} 2 \% \mathrm{G} 0,5 \%)$ & $4,05^{*}-4,24^{+}$ \\
$\mathrm{M}(\mathrm{P} 2 \% \mathrm{G} 3 \%)$ & $3,85^{*}-3,97^{+}$ \\
$\mathrm{M}(\mathrm{P} 1 \% \mathrm{G} 3 \%)$ & $4,65^{*}$ \\
$\mathrm{G} 1 \%$ & $5,62^{*}$ \\
\hline
\end{tabular}

${ }^{*} \mathrm{pH}$ - não-irradiada e ${ }^{+} \mathrm{pH}-5 \mathrm{kGy}$. 
As misturas de polissacarídeos e proteínas vêm mostrando amplas aplicações práticas. A adição de polissacarídeos (carboximetilcelulose (CMC), pectina, ágar, amido ou alginato) para a composição de filmes em $5 \%$ do total de massa de proteína permite a produção de filmes caracterizados pela melhoria das propriedades de barreira e alta resistência mecânica (Le Tien et al., 2000; Lacroix et al., 2002; Letendre et al., 2002). Aplicando a irradiação gama antes ou depois da adição de polissacarídeo a uma solução de proteína induziu a uma melhoria desse filme (Cieśla et al., 2006).

Segundo alguns autores, a alta compatibilidade de gelatina com a pectina ou dextrina em sistemas ternários sob dadas condições é devido à formação de cadeias fracas de complexos interpoliméricos (Antonov \& Zubova, 2001). As redes poliméricas interpenetrantes reticuladas de gelatina sofreram enrijecimento pela radiação em doses variando de 2 a 250 kGy.

Pela FIG. 17 pode-se observar que a viscosidade da solução $1 \%$ da mistura pectina/gelatina (1:1) a 180rpm parece se comportar de maneira análoga a este mesmo composto com velocidade de rotação igual a $250 \mathrm{rpm}$ (FIG. 18), porém com valores de viscosidade menores, fixada a temperatura e a dose de radiação. Portanto, no composto da mistura $1 \%$, o aumento da velocidade de rotação produz a diminuição da viscosidade desta substância.

Para a mistura a $2 \%$ com velocidade de rotação de $180 \mathrm{rpm}$ (FIG. 19), pode-se verificar que a viscosidade desta substância parece se comportar de maneira semelhante à mistura $1 \%$ com velocidades de rotação iguais a 180 e $250 \mathrm{rpm}$; no entanto, os valores de sua viscosidade apresentam-se maiores (FIG. 17). Portanto, na velocidade de rotação de $180 \mathrm{rpm}$, o aumento da concentração da mistura na água aumenta o valor da viscosidade. É razoável assumir que devido à alta sensibilidade dos polímeros de ácido urônico, a radiação induziu resultados de despolimerização de radicais reativos específicos envolvidos no processo, predominando este efeito sobre aquele induzido pela porção protéica (Deeble, 1990). 

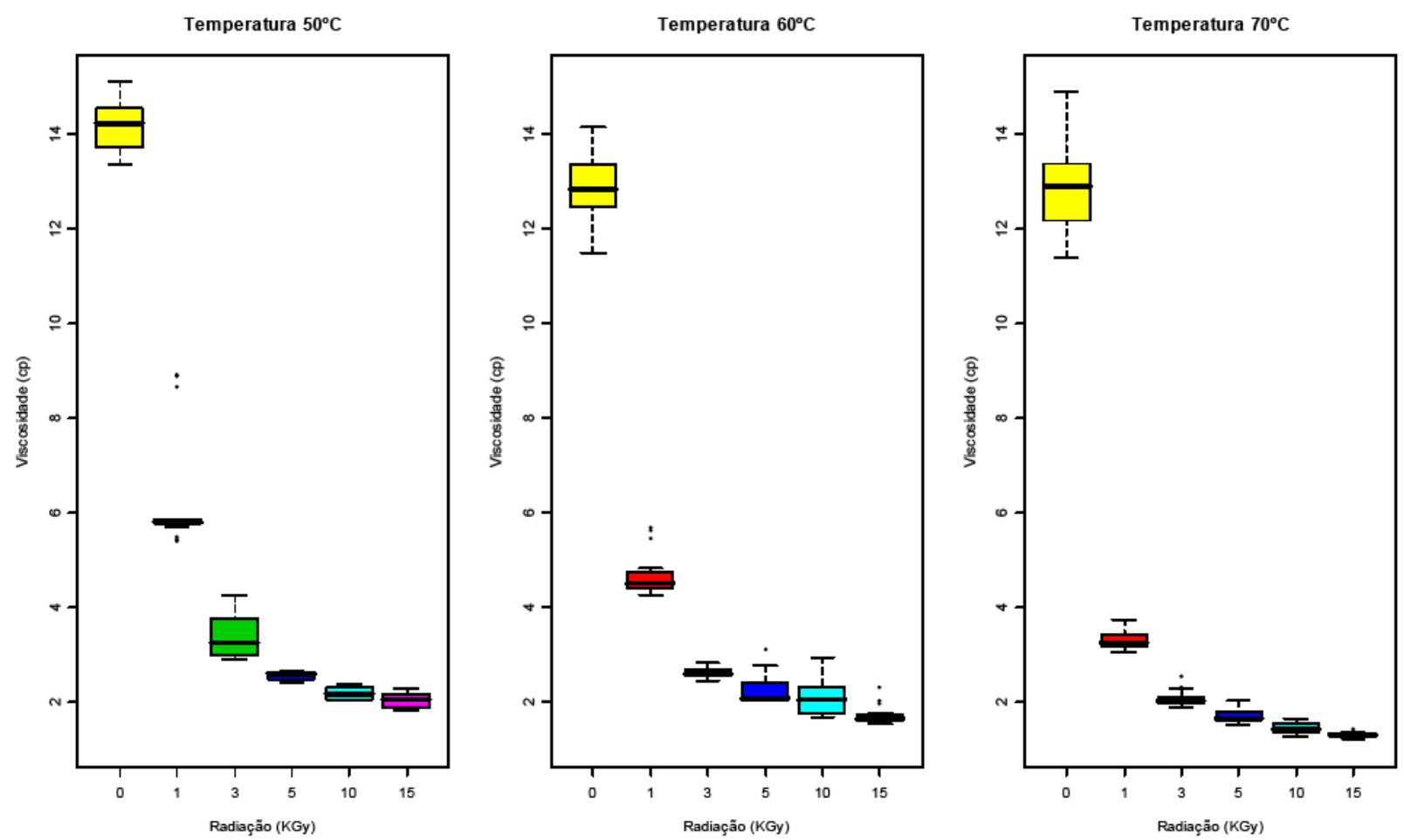

FIGURA 17 - Viscosidade vs dose da solução $1 \%$ de mistura gelatina e pectina (1:1), a $180 \mathrm{rpm}$ a 50,60 e $70^{\circ} \mathrm{C}$.
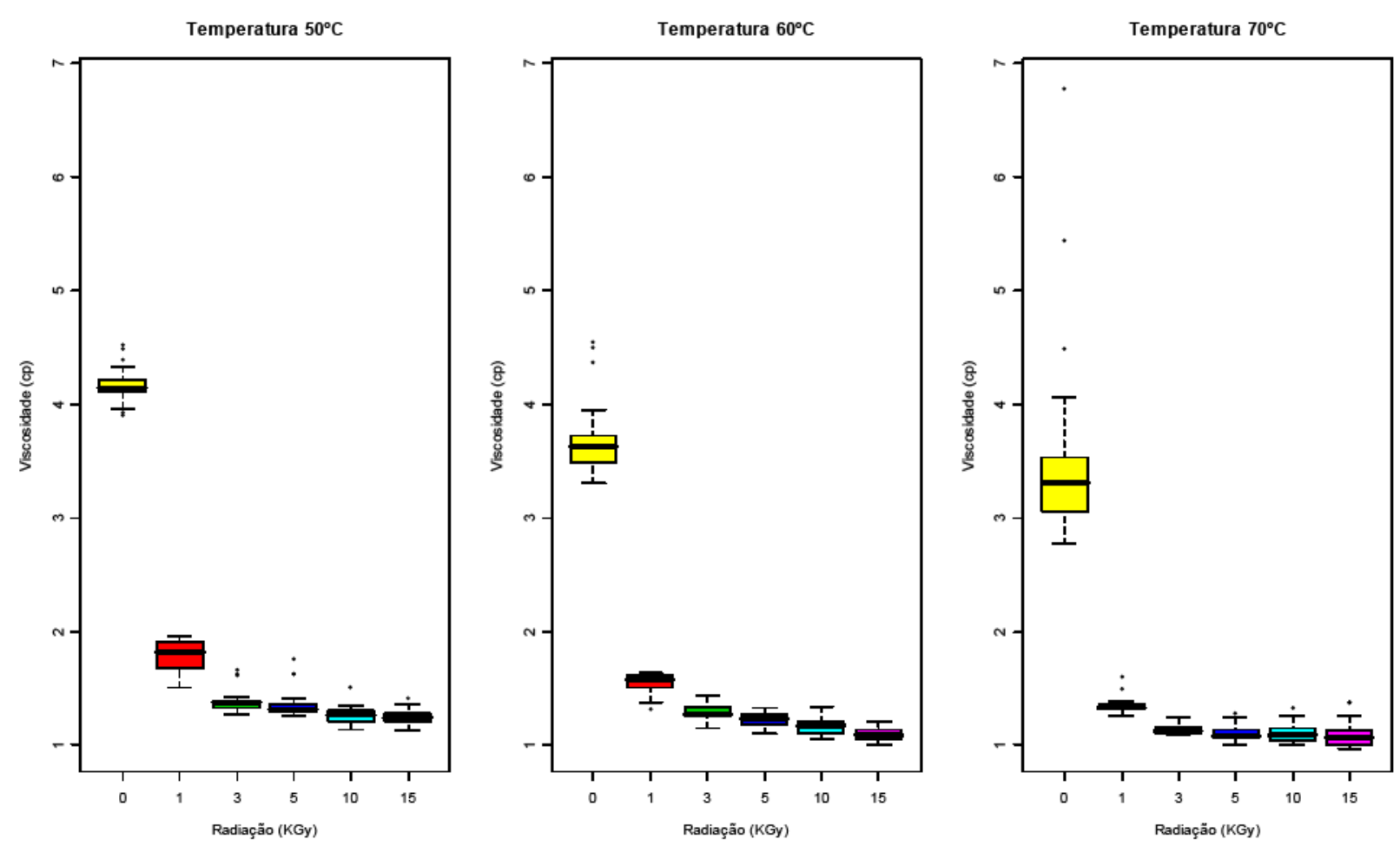

FIGURA 18 - Viscosidade vs dose da solução $1 \%$ de mistura gelatina e pectina (1:1), a $250 \mathrm{rpm}$ a 50,60 e $70^{\circ} \mathrm{C}$. 

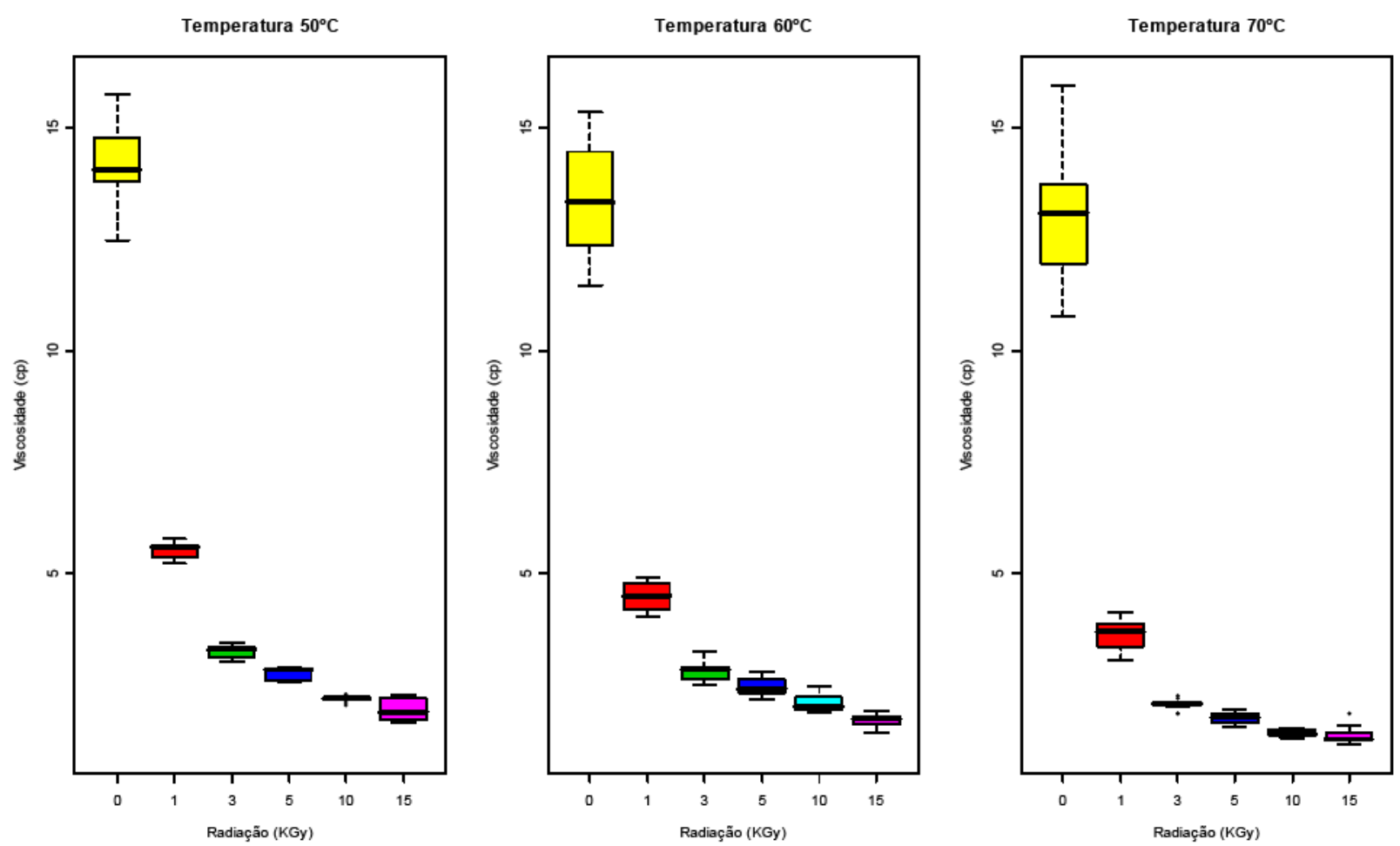

FIGURA 19 - Viscosidade vs dose da solução $2 \%$ de mistura gelatina e pectina (1:1), a $180 \mathrm{rpm}$ a 50,60 e $70^{\circ} \mathrm{C}$.

A FIG. 20 apresenta o perfil das médias das misturas onde fica evidenciada a predominância da ação da pectina sobre a gelatina no comportamento das misturas.

No presente trabalho deve-se considerar que os sistemas em estudo foram soluções aquosas diluídas. É sabido que a ação de raios gama na maioria dos polímeros em soluções aquosas diluídas ocorre principalmente por um efeito indireto: a maior parte da energia de radiação é absorvida pela água. Radicais hidroxila e átomos de hidrogênio são produzidos e reagem rapidamente com os polímeros (Von Sonntag, 1995; Ulanski et al., 1998; Kadlubowski et al., 2003). O resultado final dessa interação dependerá da estrutura química do polímero, que por sua vez vai determinar a preponderância de quebra de cadeias, transferência de hidrogênio, e ou a recombinação inter- e intramolecular. 

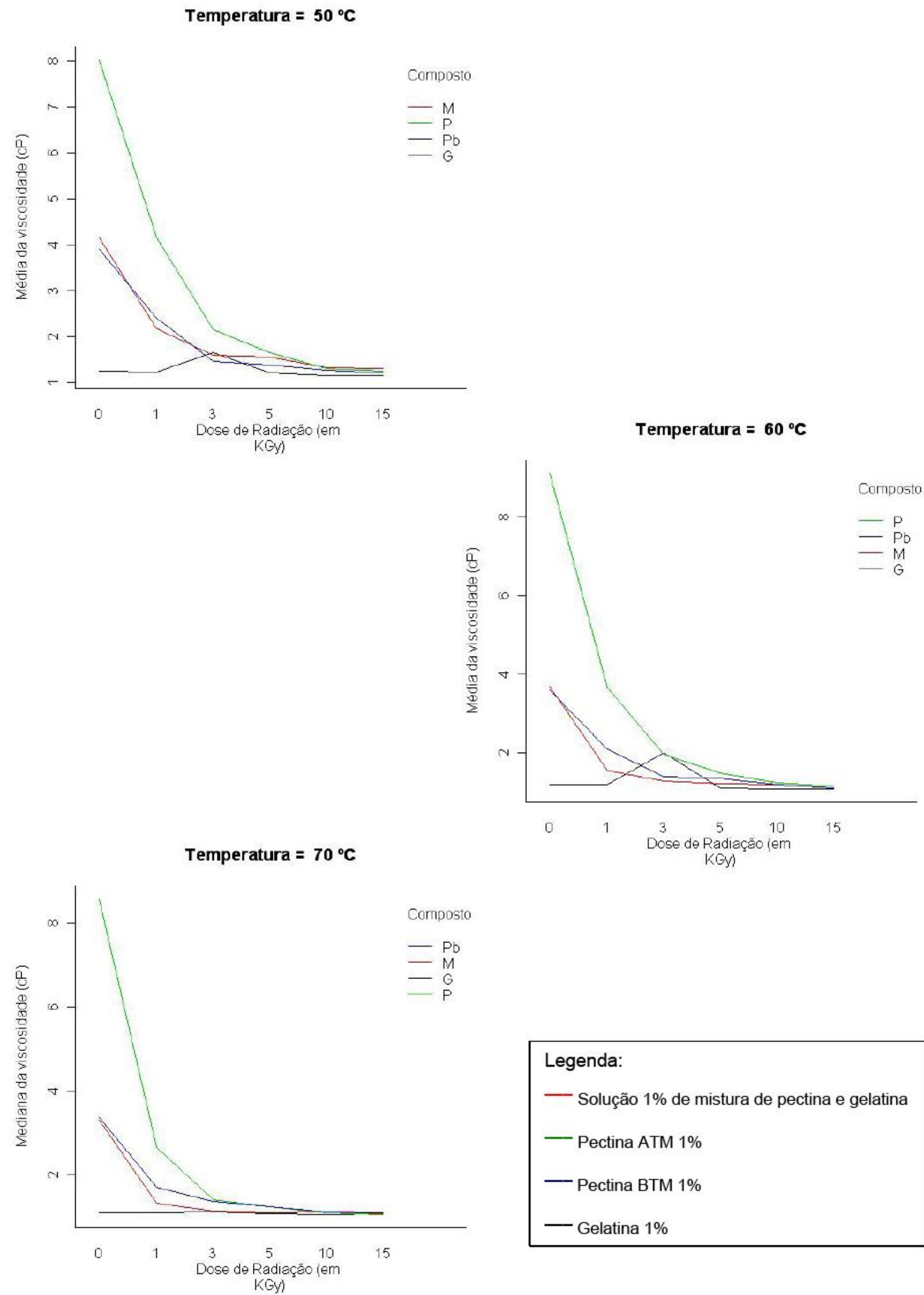

FIGURA 20 - Viscosidade das amostras vs dose de radiação. Perfis das médias, $250 \mathrm{rpm}$ a 50,60 e $70^{\circ} \mathrm{C}$. 
Na FIG. 21 estão os resultados do estudo da influência da adição de íons $\mathrm{Ca}^{2+}$ nos valores da viscosidade de soluções de pectina quando submetidas à radiação. Para todos os valores de dose de radiação ensaiadas, $1,3,5,10$ e 15kGy, e para as não-irradiadas, os valores da viscosidade foram sempre maiores na presença de íons $\mathrm{Ca}^{2+}$ mostrando dependência com a concentração. Alguns ácidos galacturônicos da pectina são metil esterificados ou acetilados. Segundo vários autores, isso sugere que seqüências de ácido D-galacturônico não-metilado seriam sítios para ligações cruzadas de cadeias poliméricas por meio de interação de sítios específicos com $\mathrm{Ca}^{2+}$ (Pilnik \& Voragen, 1991 apud Kaaber et al., 2007).

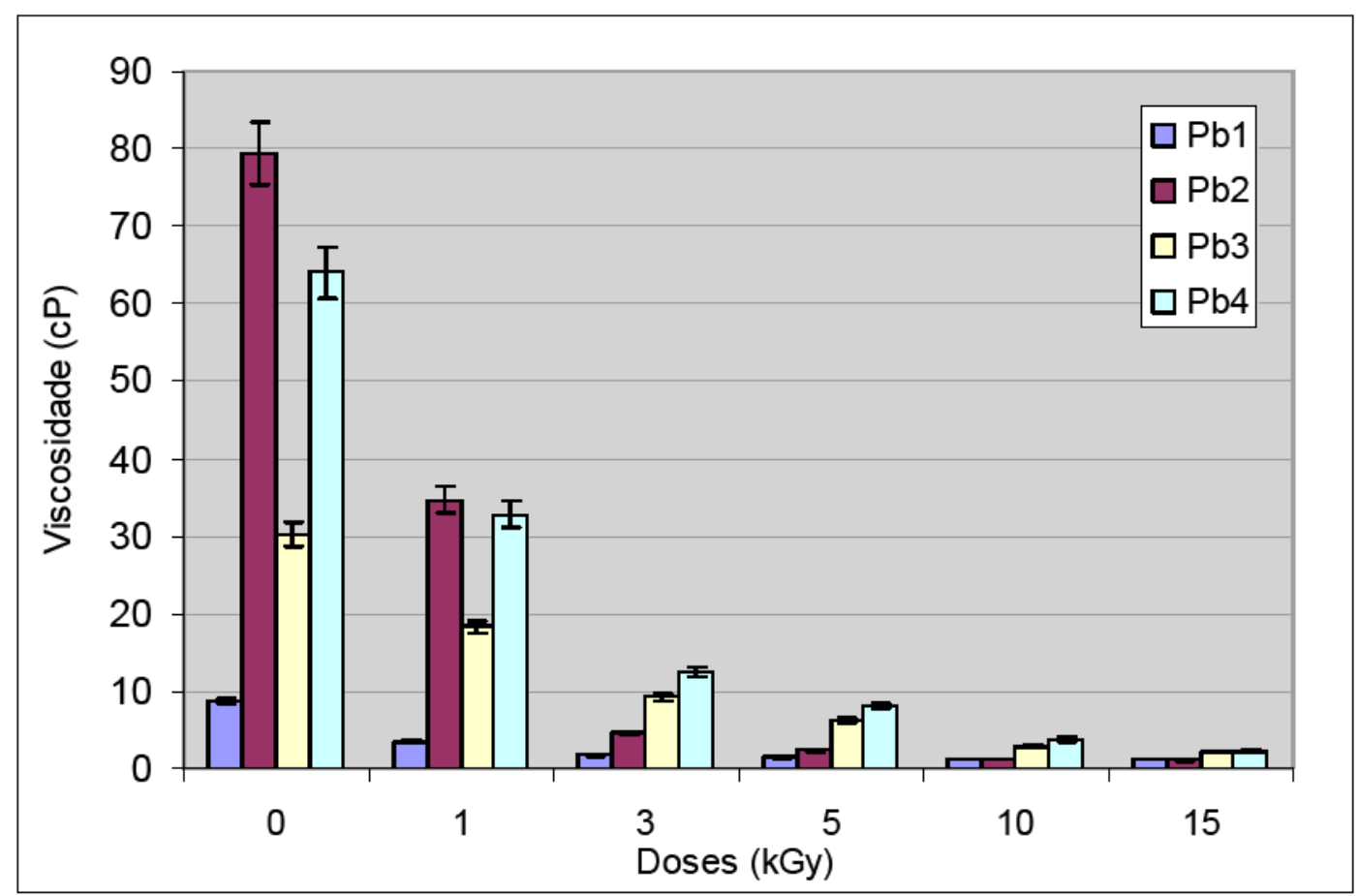

Pb1 - Pectina BTM 1\% + $\mathrm{CaCl}_{2}$ 0,05\%; Pb2 - Pectina BTM $1 \%+\mathrm{CaCl}_{2} 0,075 \%$; Pb3 - Pectina BTM 3\% + $\mathrm{CaCl}_{2}$ 0,05\%; Pb4 - Pectina BTM 3\% $+\mathrm{CaCl}_{2}$ 0,075\%.

FIGURA 21 - Viscosidade de soluções de pectina BTM a 1\% e 3\% e adição de $\mathrm{CaCl}_{2}$ em concentrações diferentes.

Pode-se observar que a amostra $\mathrm{Pb} 4$, solução com $3 \%$ de pectina BTM adicionada de $0,075 \%$ de $\mathrm{CaCl}_{2}$, obteve os valores mais altos de 
viscosidade, perdendo apenas para a amostra $\mathrm{Pb} 3$, não-irradiada e irradiada com dose de 1kGy (FIG. 21). A presença de íons cálcio na solução de pectina BTM ocasionou a formação de rede e conseqüente formação de gel (Ribeiro, Seravalli, 2004). Segundo Lofgren et al. (2002) a adição de $\mathrm{Ca}^{2+} \mathrm{e}$ sacarose mostraram um alto efeito de sinergismo nas propriedades reológicas da mistura de géis de pectina ATM e BTM.

Na FIG. 22 são comparadas diversas misturas, nas quais ora predomina pectina, ora gelatina em relação a soluções puras de ambas. Os valores de viscosidade são sempre mais altos nas misturas onde predomina a pectina e fica aqui também evidenciada a sua maior influência quando presente na mistura. Também fica evidente a importância da concentração de hidrocolóide em todos os casos.

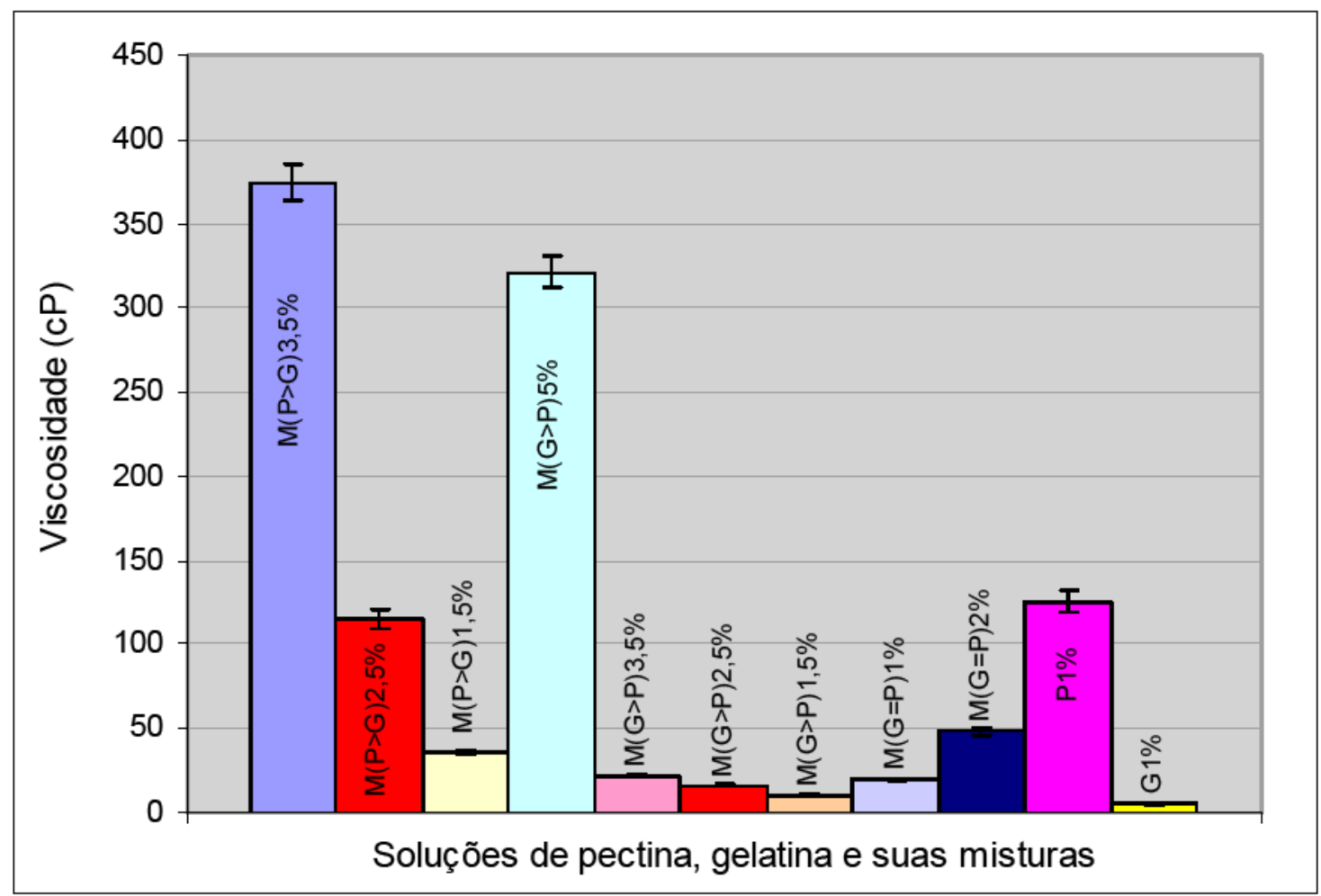

FIGURA 22 - Influência da concentração na viscosidade das soluções de pectina e gelatina e suas misturas não irradiadas. 


\section{CONCLUSÕES}

- Com base no trabalho realizado, conclui-se que as soluções de pectina e gelatina apresentaram-se como fluidos não-newtonianos, pois a viscosidade se altera com a tensão de cisalhamento e o torque. Existe uma correlação linear entre essas variáveis;

- A correlação entre velocidade de rotação e a taxa de cisalhamento é aproximadamente igual a 1, ou seja, o valor da taxa de cisalhamento deve poder ser calculado através do valor da velocidade de rotação;

- A correlação entre a tensão de cisalhamento e o torque é igual a 1 , ou seja, a relação entre a tensão de cisalhamento e o torque pode ser descrita pela seguinte função matemática: Tensão_cis $=0,4^{*}$ Torque;

- Dada uma velocidade de rotação, a tensão de cisalhamento e o torque influenciam linearmente a viscosidade, onde a velocidade de rotação influencia no coeficiente angular desta linearidade;

- A viscosidade de maneira geral diminui com o aumento da velocidade de rotação aplicada;

- A viscosidade de maneira geral aumenta com o aumento da concentração das amostras;

- Para soluções de gelatina a irradiação não exerce influência sobre a viscosidade; apenas quando aplicada doses de $3 \mathrm{kGy}$, ocorre um aumento na viscosidade;

- A viscosidade decresce exponencialmente conforme se aumenta a dose de radiação para soluções de pectina, seja ATM ou BTM. Há uma leve redução da viscosidade com o aumento da temperatura, na faixa de 50 a $70^{\circ} \mathrm{C}$, embora não seja significativa estatisticamente; 
- A temperatura não influencia significativamente no valor da viscosidade das soluções de pectina BTM $1 \%$ e pectina ATM 1\%. Já para as amostras de gelatina $0,5 \%$ e soluções $1 \%$ e $2 \%$ da mistura de pectina e gelatina (1:1) o aumento da temperatura diminui o valor da viscosidade; 


\section{REFERÊNCIAS BIBLIOGRÁFICAS}

AGNES, M. Webster's Third New International Dictionary. London: Encyclopaedia Britannica, Inc, p. 1663, 1976.

AKHLAQ, M. S.; SCHUCHMANN, H.-P.; VON SONNTAG, C. Degradation of the polysaccharide alginic acid: a comparison of the effects of UV light and ozone. Environmental science \& technology. v. 24, p. 379-383, 1990.

AL-ASSAF, S.; PHILLIPS, G.O.; WILLIAMS, P.A. Controlling the molecular structure of food hydrocolloids. Food hydrocolloids, v.20,n. 2-3, p.369-377, 2006.

ALISTE, A. J.; MASTRO, N. L. Anomalous Rheological Behaviour of GelatinCarrageenan-Water System Induced by lonizing Radiation. Molecular Crystals and Liquid Crystals. v. 448, p. 179/781-185/787, 2006.

ALISTE, A.J.; VIEIRA, F.F.; DEL MASTRO, N.L. Radiation effects on agar, alginates and carrageenan to be used as food additives. Radiation Physics and Chemistry. v. 57, n. 2, p. 305-308, 2000.

ALVAREZ, M. Review: active food packaging. Food sci. technol. int. v. 6, n. 2 , p. $97-108,2000$.

ALVES, V.; COSTA, N.; HILLLIOU, L.; LAROTONDA, F.; GONÇALVES, M.; SERENO, A.; COELHOSO, I. Design of biodegradable composite films for food packaging. Desalination. v. 199, p. 331-333, 2006.

ANTONIEWSKI, M.N.; BARRINGER, S.A.; KNIPE, C.L.; ZERBY, H.N. Effect of a gelatin coating on the shelf life of fresh meat. Journal of food science. v. 72, n. 6, p. E382-E387, 2007.

ANTONOV, Y. A.; ZUBOVA, O. M. Phase state of aqueous gelatinpolysaccharide (1)-polysaccharide (2) systems. International journal of biological macromolecules. v. 29, n. 2, p. 67-71, Aug. 2001.

ANTTILA, H.; SONTAG-STROHM, T.; SALOVAARA, H. Viscosity of betaglucan in oat products. Agricultural and food science, v. 13, n. 1-2, p. 80-87, 2004.

BANDAZHEVSKAYA, G. S.; NESTERENKO, V. B.; BABENKO, V. I.; BABENKO, I. V.; YERKOVICH, T. V.; BANDAZHEVSKY, Y. I. Relationship between Caesium ((Cs)-C-137) load, cardiovascular symptoms, and source of food in "Chernobyl" children - preliminary observations after intake of oral apple pectin. Swiss Medical Weekly, v. 134, p. 725-729, Dec. 2004.

BANDAZHEVSKY, Y. Patophysiology of incorporated radioactive exposition. Gomel Medical Institute. Gomel, p. 103, 1997. 
BANDAZHEVSKY, Y.; NESTERENKO V.B. and others. Structural-functional effects of the radionuclides incorporated into the organism. Gomel Medical Institute. Gomel, p. 151, 1997.

BANJONGSINSIRI, P.; KENNEY, S.; WICKER, L. Texture and distribution of pectic substances of mango as affected by infusion of pectinmethylesterase and calcium. Journal of the science of food and agriculture. v. 84, n. 12, p. 1493-1499, Sep. 2004.

BARRANGOU, L.M.; DRAKE, M.A.; DAUBERT, C.R.; FOEGEDING, E.A. Sensory texture related to large-strain rheological properties of agar/glycerol gels as a model food. J. Texture Stud. v. 37, p. 241-62, 2006.

BAXENDALE, J.H.; BYWATER, S.; EVANS, M.G. Relation between molecular weight and intrinsic viscosity for polymethyl methacrylate. Journal of Polymer Science, v. 1, n.4, p. 237-244, 1946.

BENGMARK, S. Use of some pre-, pro- and synbiotics in critically ill patients. Best Practice \& Reasearch in Clinical Gastroenterology, v. 17, p. 833-848, 2003.

BENKEBLIA, N.; ONODERA, S.; SHIOMI, N. Effect of gamma irradiation and temperature on fructans (fructo-oligossacharides) of stored onion bulbs Allium cepa L. Food chemistry. v. 87, p. 377-382, 2004.

BERARDINI, N.; KNODLER, M.; SCHIEBER, A.; CARLE, R. Utilization of mango peels as a source of pectin and polyphenolics. Innovative food science \& emerging technologies. v. 6, n. 4, p. 442-452, Dec. 2005.

BLACK, S.A.; SMIT, C.J.B. The effect of demethylation procedures on the quality of low-ester pectins used in dessert gels. Journal of Food Science. v. 37, n. 2, p. 730-732, 1972.

BOBBIO, F.O.; BOBBIO, P.A. Introdução à Química de Alimentos. 2. ed. São Paulo: Livraria Varela, 1989.

BOHIDAR, H.B. Hydrodynamic properties of gelatin in dilute solutions. Int. J. Biol Macromol. v. 23, p. 1-6, 1998.

BORÉM, A. A história da Biotecnologia. Biotecnologia Ciência e Desenvolvimento, no VIII, n.34, p. 10-12, 2005.

BOSCH, V. A., La irradiación de los alimentos. Seguridad Nuclear, n. 35, 2005.

BOT, A.; VAN AMERONGEN, I.A.; CROOT, R.D.; HOEKSTRA, N.L.; AGTEROF, W.G.M. Large deformation rheology of gelatin gels. Polym Gels NetW. v. 4, p. 189-227, 1996.

BOURNE, M.C. Food texture and viscosity: concept and measurement. New York: Academic. p. 427, 2002. 
BRASIL. Ministério da Saúde, Agência Nacional de Vigilância Sanitária. Resolução $n^{\circ} 21,26$ de janeiro de 2001. Dispõe sobre regulamento técnico para irradiação de alimentos. Diário Oficial, [da] República Federativa do Brasil, Brasília, D.F, Seção 1, Parte Eletrônica, p.35, 29 jan. 2001.

BREITFELLNER, F.; SOLAR, S.; SONTAG, G. Effect of $\gamma$-irradiation on phenolic acid in strawberry. Journal of food science. v. 67, n. 2, p. 517-521, 2002.

CARTER, W.C.; SCOTT, R.L.; MAGAT, M. The viscosity molecular weight, and viscosity of sodium alginate. Journal of american chemical society. v. $68, \mathrm{n}$. 8 , p. 1480-1483, 1946.

CERDA, J.J.; ROBBINS, F.L.; BURGIN, C.W.; BAUMGARTNER, T.G.; RICE, R.W. The effects of grapefruit pectin on patients at risk for coronary heart disease without altering diet or lifestyle. Clinical cardiology. v. 11, n. 9, p. 589-594, 1988.

CHAPLIN, M. Water structure and science. Gelatin. London, U.K., July, 2007. Disponível em: <http://www.Isbu.ac.uk/water/hygel.html\#319>.

Acesso em: 29 nov. 2007.

CHOE, E.; MIN, D.B. Chemistry and reactions of reactive oxygen species in foods. Critical reviews in food science and nutrition. v. 46, n. 1, p. 1-22, 2006

CIEŚLA, K.; SALMIERI, S.; LACROIX, M. $\gamma$-Irradiation Influence on the Structure and Properties of Calcium Caseinate-Whey Protein Isolate Based Films. Part 2. Influence of Polysaccharide Addition and Radiation Treatment on the Structure and Functional Properties of the Films. Journal of agricultural and food chemistry. v. 54, p. 8899-8908, 2006.

CILURZO, F.; SELMIN, F.; MINGHETTI, P.; MONTANARI, L.; LENARDI, C.; ORSINI, F.; POLETTI, G. Comparison Between Gamma and Beta Irradiation Effects on Hydroxypropylmethylcellulose and Gelatin Hard Capsules. AAPS PharmSciTech. v. 6, n. 4, 2005. Disponível em:

$<$ http://www.aapspharmscitech.org $>$.

Acesso em: 17 abr. 2007.

CLARK, L. Foods which protect against radioactivity. Are you radioactive, Devin, M.A., cap. 8, 1974. Disponível em:

$<$ http://www.mindcontrolforums.com/rad_8.htm>.

Acesso em: 09 ago. 2004.

CORADIN, T.; BAH, S.; LIVAGE, J. Gelatin/silicate interactions: from nanoparticles to composite gels. Colloids and surfaces b: biointerfaces, v. 35, n. 1 , p. $53-58,2004$. 
COUGHLAN, K.; SHAW, N.B.; KERRY, J.F.; KERRY, J.P. Combined effects of proteins and polysaccharides on physical properties of whey protein concentrate-based edible films. Journal of food science. v. 69, n. 6 , p. E271-E275, 2004.

COX, W.P.; NIELSEN, L.E.; KEENEY, R. Dynamic viscosity and shear modulus of molten polystyrene as a function of molecular weight. Journal of polymer science, v. 26, n. 114, p. 365-374, 1957.

CP KELCO BRASIL S/A. Types of pectin. Material cedido por <steen.hoejgaard@cpkelco.com>.

Acesso em: 21 jul. 2004.

DEEBLE, D,J.; BOTHE, E.; SCHUCHMANN, H.-P.; PARSONS, B.J.; PHILLIPS, G.O.; VON SONNTAG, C. The kinetics of hydroxyl-radical -induced strand breakage of hyaluronic acid. A pulse radiolysis study using conductometry and laser-light-scattering. Z. Naturforsch., C J. biosciences. v. 45, n. 9-10, p. 1031-1043, 1990.

DEL MASTRO, N.L. Sterile foods to be used in hospitals and military rations. Brazil research and development journal, v. 2, n. 1, p.1-4, 1999.

DIEHL, J.F. Food irradiation - past, present and future. Radiation Radiation Physics and Chemistry. v.63, p.211-215, 2002.

DI GIOLA, L.; CUQ, B.; GUILBERT, S. Effect of hydrophilic plasticizers on thermomechanical properties of corn gluten meal. Cereal chem., v. 75, n. 4, p. 514-519, 1998.

DOGAN, M.; KAYACIER, A.; IC, E. Rheological characteristics of some food hydrocolloids processed with gamma irradiation. Food hydrocolloids, v. 21, p. 392-396, 2007.

DOGBEVI, M. K.; VACHON, C.; LACROIX, M. Physicochemical and microbiological changes in irradiated fresh pork loins. Meat science, v. 51, p. 349-354, 1999.

DONNAN, F.G.; ROSE, R.C. Osmotic pressure, molecular weight, and viscosity of sodium alginate. Canadian journal of research section b-chemical science, v. 28, n. 3, p. 105-113, 1950.

DZIEZAK, J.D. Instruments for measuring viscosity and flow. Food technology, v. 45, n. $7,1991$.

FENNEMA, O.R. Food chemistry. 3. ed. New York, N.Y.: Marcel Dekker, Inc, p. 216-217, 1996.

FISHMAN, M.L.; COFFIN, D.R.; KONSTANCE, R.P.; ONWULATA, C.I. Extrusion of pectin/starch blends plasticized with glycerol. Carbohydrate polymers. v. 41, p. 317-325, 2000. 
FISHMAN, M.L.; COFFIN, D.R.; ONWULATA, C.I.; KONSTANCE, R.P. Extrusion of pectin and glycerol with various combinations of orange albedo and starch. Carbohydrate polymers. v. 57, p. 401-413, 2004.

FOEGEDING, E.A.; BROWN, J.; DRAKE, M.A.; DAUBERT, C.R. Sensory and mechanical aspects of cheese texture. Int. Dairy Journal. v. 13, p. 585-591, 2003.

FURUSAWA, K.; TERAO, K.; NAGASAWA, N.; YOSHII, F.; KUBOTA, K.; DOBASHI, T. Nanometer-sized gelatin particles prepared by means of gamma-ray irradiation. Colloid \& polymer science. v. 283, p. 229-233, 2004.

GARZA, S.; YUSTE, J. Los geles de pectina y su aplicación en la industria alimentaria. Alimentaria. V. 40, n. 342, p. 93 - 98, 1993.

GENERAL STANDARD FOR IRRADIATED FOODS. STAN 106-1983, REV. 1-2003 1. Disponivel em:

$<$ http://www.codexalimentarius.net/download/standards/16/CXS_106_2003e.pdf >. Acesso em: 19 nov. 2007.

GENNADIOS, R.; HANNA, M. A.; KURTH, L. B. Application of edible coatings on meats, poultry and seafoods: a review. Lebensmittel- Wissenschaft und Technologie, v. 30, p. 337 - 350, 1997.

GHORPADE, V.M.; LI, H.; GENNADIOS, A.; HANNA, M.A. Chemically modified soy protein films. Journal of food science. v. 63, p. 225-228, 1995.

GILSENAN, P.M.; ROSS-MURPHY, S.B. Viscoelasticity of thermoreversible gelatin gels from mammalian and piscine collagen. J. rheol. v. 44, p. 871-82, 2000.

GÓMEZ-ESTACA, J.; MONTERO, P.; GIMÉNEZ, B.; GÓMEZ-GUILLÉN, M.C. Effect of functional edible films and high pressure processing on microbial and oxidative spoilage in cold-smoked sardine (Sardina pilchardus). Food chemistry. v. 105, p. 511 - 520, 2007.

GOYCOOLEA, F.M.V.; CÁRDENAS, A.B. Propiedades gelificantes de la pectina del nopal. In: XXV Premio Nacional de Ciencia y Tecnología de Alimentos 2001. Industria Mexicana de Coca Cola y el CONACyT. Ciudad de México, 29 octubre 2001.

GUDMUNDSSON, M. Rheological properties of fish gelatin. Journal of food science. v. 67, p. 2172-2176, 2002.

GUILBERT, S. Protein-based bioplastics: formulation. Thermoplastic processing and main applications. The Industrial Applications of Bioplastics 2002, York, UK, 3-5 Fev., 2002, Proceedings..., lowa Department of Economic Development, European Office, Frankfurt, p. 22-37, 2002. 
GUILLOTIN, S.E.; BAKX, E.J. ; BOULENGUER, P.; SCHOLS, H.A.; VORAGEN, A.G.J. Determination of the degree of substitution, degree of amidation and degree of blockiness of commercial pectins by using capillary electrophoresis. Food hydrocolloids. v. 21, p. 444-451, 2007.

HARRIS, P.J.; SMITH, B.G. Plant cell walls and cell-wall polysaccharides. International journal of food Science and technology. v. 41 (supplement 2), p. 129-143, 2006.

HAUG, I.J.; DRAGET, K.I.; SMIDSRØD, O. Physical behaviour of fish gelatin-kcarrageenan mixtures. Carbohydrate polymers, v. 56, n. 1, p. 11-19, 2004.

HAYES, D.J.; MURANO, E.A.; MURANO, P.S.; OLSON, D.G.; SAPP, S.G. Food irradiation: a sourcebook. Ames, I.A.: Academic Press, Inc., 1995.

HUGHES, C.C. Guía de aditivos. Zaragoza, Esp.: Acribia S.A., 1994.

IAEA. Radiation in everyday life. Vienna, Austria. 2003. Disponível em: $<$ http://www.iaea.org/icgfi/>.

Acesso em: 14 ago. 2004.

ICGFI. INTERNATIONAL CONSULTATIVE GROUP ON FOOD IRRADIATION. Facts about food irradiation., IAEA, Vienna, 1999.

IFT. 1983. Radiation preservation of foods. Food technology. v. 37 , n. 2 , p. $55-60,2000$.

INAMURA, P.Y.; MAESTRO, N.L. Efeito da radiação gama na resistência a compressão de géis. In: XLVII CONGRESSO BRASILEIRO DE QUÍMICA ABQ/RN, 17-21 setembro, 2007, Natal, RN. Resumos... Natal.

INOKUTI, M. Charms of radiation research. In:JAERI-CONF., cap. 4.7, p. $250-265$, Proceedings...2005.

INSTITUTE OF RADIATION MEDICINE MoHP RB. Catalogue of the exposition doses for the population of the human settlements of the Republic of Belarus. Minsk, p. 94, 1992.

JEON, Y. I.; KAMIL, J. Y. V. A.; SHAHIDI, F. Chitosan as an edible invisible film for quality preservation of herring and Atlantic cod. Journal of agricultural and food chemistry, v. 20, p. 5167-5178, 2002.

JO, C.; KANG, H.; LEE, N.Y.;KWON, J.H.; BYUN, M.W. Pectin- and gelatin-based film: effect of gamma irradiation on the mechanical properties and biodegradation. Radiation Physics and Chemistry. v. 72, p. 745-750, 2005.

JOLY-DUHAMEL, C.; HELLIO, D.; DJABOUROV, M. All gelatin networks: 1. Biodiversity and physical chemistry. Langmuir. v. 18, p. 7208-7217, 2002. 
KAABER, L.; KAACK, K.; KRIZNIK, T.; BRÅTHEN, E.; KNUTSEN, S.H. Structure of pectin in relation to abnormal hardness after cooking in pre-peeled, cool-stored potatoes. LWT-Food Science and technology. v. 40, p. 921-929, 2007.

KADLUBOWSKI, S.; GROBELNY, J.; OLEJNICZAK, W.; CICHOMSKI, M.; ULANSKI, P. Pulses of fast electrons as a tool to synthesize poly (acrylic acid) nanogels. Intramolecular cross-linking of linear polymer chains in additive-free aqueous solution. Macromolecules. v. 36, p. 2484-2492, 2003.

KANG, H.J.; JO, C.; KWON, J.H.; KIM, J.H.; CHUNG, H.J.; BYUN, M.W. Effect of a pectin-based edible coating containing green tea powder on the quality of irradiated pork patty. Food Control. v. 18, p. 430-435, 2007.

KESTER, J.J.; FENNEMA, O.R. Edible films and coatings: a review. Food technology. p. 47 - 59, dez. 1986.

KRATCHANOVA, M.; PAVLOVA, E.; PANCHEV, I. The effect of microwave heating of fresh orange peels on the fruit tissue and quality of extracted pectin. Carbohydrate polymers, v. 56, n. 2, p. 181 - 185, 2004.

KUMAR, V.; BHARDWAJ, Y.K.; SABHARWAL, S.; MOHAN, H. Radiation effect on poly (vinylbenzyltrimethylammonium chloride) in aqueous solution: pulse radiolysis and steady-state study. Journal of radiation research, v. 45, n. 2, p. 291 - 301, Jun. 2004.

LABIB, A.A.S.; ELASHWAH, F.A.; OMRAN, H.T.; ASKAR, A. Heat-inactivation of mango pectinesterase and polygalacturonase. Food chemistry. v. 53, n. 2, p. $137-142,1995$.

LACROIX, M.; LE, T. C.; OUATTARA, B.; YU, H.; LETENDRE, M.; SABATO, S. F.; MATEESCU, M. A.; PATTERSON, G. Use of gamma irradiation to produce films from whey, casein and soya proteins: structure and functional characteristics. Radiation physics and chemistry. v. 63, p. 827 - 832, 2002.

LACROIX, M.; OUATTARA, B. Combined industrial processes with irradiation to assure innocuity and preservation of food products: a review. Food research international, v. 33, p. 719 - 724, 2000.

LEE, M.; LEE, S.; SONG, K.B. Effect of $\gamma$-irradiation on the physicochemical properties of soy protein isolate films. Radiation physics and chemistry. v. 72, p. $35-40,2005$.

LEHNINGER, A.L. Bioquímica: componentes moleculares das células. 2.ed. São Paulo: Editora Edgard Blücher LTDA, 1976.

LETENDRE, M.; D'APRANO, G.; LACROIX, M.; SALMIERI, S.; ST. GELAIS, D. Physicochemical properties and bacterial resistance of biodegradable milk protein films containing agar and pectin. Journal of agricultural and food chemistry. v. 50, p. 6017 - 6022, 2002. 
LE TIEN, C.; LETENDRE, M.; ISPAS-SZABO, P.; MATEESCU, M.A.; DELMASPATERSON, G.; YU, H.-L.; LACROIX, M. Development of biodegradable films from whey proteins by cross-linking and entrapment in cellulose. Journal of agricultural and food chemistry. v. 48, p. $5556-5575,2000$.

$\mathrm{LI} \mathrm{J}, \mathrm{CHEN} \mathrm{H}$. Transglutaminase catalyzed crosslinking on functional properties of whey protein-based edible films.In: IFT ANNUAL MEETING, III. July $24-28$, 1999, Chicago, U.S.A. , Abstracts. Chicago , U.S.A. , p. 23, 1999.

LOFGREN, C.; WALKENSTROM, P.; HERMANSSON, A.M. Microstructure and rheological behavior of pure and mixed pectin gels. Biomacromolecules. v. 3, n. 6 , p. $1144-1153$, nov-dec 2002.

MAFTOONAZAD, N.; RAMASWAMY, H.S.; MARCOTTE, M. Moisture Sorption Behavior, and Effect of Moisture Content and Sorbitol on Therm-Mechanical and Barrier Properties of Pectin Based Edible Films. International journal of food engineering. v. 3, n. 4, p. 1-24, 2007. Disponível em: $<$ http://www.bepress.com/ijfe/vol3/iss4/art10>. Acesso em: 23 out. 2007.

MAIZURA, M.; FAZILAH, A.; NORZIAH, M.H.; KARIM, A.A. Antibacterial activity and mechanical properties of partially hydrolyzed sago starch-alginate edible film containing lemongrass oil. Journal of food science. v. 72 , n. 6 , p. C324 - C330, 2007.

MARUDOVA, M.; MACDOUGALL, A.J.; RING, S.G. Pectin-chitosan interactions and gel formation. Carbohydrate polymers, v. 56, n. 2, p. 1933 - 1939, 2004.

MERRIAM, G.C. Webster's Third New International Dictionnary. Chicago: Encyclopaedia Britannica, Inc. G\&C. Merriam Co., p. 662, 1976.

MEYER, L.H. Food chemistry. Westport: The Avi Publishing Company, Inc., p. $128,1975$.

MILLER, K.S.; CHIANG, M.T.; KROCHTA, J.M. Heat curing of whey proteins films. Journal of food science. v. 62, p. 1189 - 1193, 1997.

MODIFIED CITRUS PECTIN ASSOCIATED WITH IMPROVED PSA DOUBLING TIME. Prostate cancer and prostatic diseases. Nature group journal. v. 6, 2003. Disponivel em: <http://www.lef.org/whatshot/\#mcpa>. Acesso em: 09 ago. 2004.

MUGNAINI, M.R. O valor da pectina. Araraquara, 2002. Disponível em: $<$ http://www.laranjabrasil.com.br/default.htm?link=search\&pagina=pesquisa\&qu ery=pectina\&go $. x=23 \& g o . y=14>$.

Acesso em: 04 ago. 2004.

MUÑOZ, A.M.; PANGBORN, R.M.; NOBLE, C. Sensory and mechanical attributes of gel texture. I. Effect of gelatin concentration. $J$ texture stud. v. 17, p. $1-16,1986 \mathrm{~A}$. 
MUÑOZ, A.M.; PANGBORN, R.M.; NOBLE, C. Sensory and mechanical attributes of gel texture. II. Gelatin, sodium alginate and kappa-carrageenan gels. J texture stud. v. 17 , p. 17 - 36, 1986B.

MYINT, P.; DEEBLE, D.J.; BEAUMONT, P.C.; BLAKE, S.M.; PHILLIPS, G.O. The reactivity of various free radicals with hyaluronic acid: steady-state and pulse radiolysis studies. Biochim. Biophys. Acta, v. 925, p. 194 - 202, 1987.

NAVARRO, R.F. Fundamentos de reologia de polímeros. Caxias do Sul: EDUCS: Editora da Universidade de Caxias do Sul, 1997.

NESTERENKO V. Chernobyl catastrophe. Radiation protection of the population. Minsk, Pravo i ekonomika, 1997.

NESTERENKO, V.B. Impact of radiation on the health of children in Belarus 12 years after Chernobyl. Minsk, Belarus: National Academy of Sciences of the Republic of Belarus, 1998. Disponivel em:

<http://www.fortunecity.com/boozers/vines/860/Nester/english/nester1.htm>.

Acesso em: 09 ago. 2004.

NESTERENKO, V.B. The Pectin Project. Minsk, Belarus: National Academy of Sciences of the Republic of Belarus, 1998. Disponivel em: <http://www.comitebandajevsky.org/zzz_angl/sciences_publications/pectin_project.htm>.

Acesso em: 09 ago. 2004.

NURJAYA, S.; WONG, T.W. Effect of microwave on drug release properties of matrices of pectin. Carbohydrate polymers. v. 62, p. 245-257, 2005.

OGBADU, G.H. Effect of gamma irradiation on the protein, amino acids and carbohydrates contents of soya-gari diet. Radiation physics and chemistry. v. 14 , p. $769-773,1979$.

OUSSALAH, M.; CAILLET, S.; SALMIE'RI, S.; SAUCIER, L.; LACROIX, M. Antimicrobial and antioxidant e.ects of milk protein-based film containing essential oils for the preservation of whole beef muscle. Journal of agricultural and food chemistry. v. 52, p. 5598 - 5605, 2004.

PARK, S-I.; ZHAO, Y. Development and Characterization of Edible Films from Cranberry Pomace Extracts. Journal of food science. v. 71, n. 2, p. E95-E102, 2006.

PILNIK, W.; VORAGEN, A.G.J. The significance of endogenous and exogenous pectin enzymes in fruit and vegetable processing. In P. E. Fox (Ed.), Food enzymology. London : Elsevier Applied Science. p. 303-336, 1991.

PILNIK, W., VORAGEN, A.G.J., NEUKOM, H., NITTNER, E. UIImann's Encyclopaedie der Technischen Chemie. Weinheim: Verlag Chemie $\mathrm{GmbH}$. v. 19, p. $233-263,1980$.

PONG, S.H.; LU, C.P.; WANG, M.C.; CHIU, S.H. Polypropylene degradation control during reactive extrusion. Journal of applied polymer science, v. 95, n. 2, p.280-289, Jan. 152005. 
POTTER, N.N. Food science. 4.ed. New York, N.Y.: Van Nostrand Reinhold, 1986.

PRAKASH, A.; INTHAJAK, P.; HUIBREGTSE, H.; CAPORASO, F.; FOLEY, D.M. Effect of low-dose gamma irradiation in conventional treatments on shelf life and quality characteristics of diced celery. Journal of food science. v. 65 , n. 6 , p. 1070-1075, 2000.

PRUZINEK, J.; HOLA, O. Starch degradation by irradiation. Journal radional. nucl. lett. v. 118, p. 427-431, 1987.

RAJVAIDYA, S; BAJPAI, R.; BAJPAI, A.K. Effect of gamma irradiation on the interpenetrating networks of gelatin and polyacrylonitrile: Aspect of crosslinking using microhardness and crosslink density measurements. Journal of applied polymer science. v. 101, n. 4, p. 2581-2586, 27 May 2006.

RAMÍREZ, J.A.; RODRÍGUEZ, N.R.; URESTI, R.M.; VELAZQUEZ, G.; VÁZQUEZ, M. Fiber-rich functional fish food from striped mullet (Mugil cephalus) using amidated low methoxyl pectin. Food hydrocolloids. v. 21, p. 527-536, 2007.

RECOMMENDED INTERNATIONAL CODE OF PRACTICE FOR RADIATION PROCESSING OF FOOD. CAC/RCP 19-1979. Rev. 2-2003. Disponível em: $<$ http://www.codexalimentarius.net/download/standards/18/CXP_019e.pdf>. Acesso em: 19 nov. 2007.

RESSOUANY, M.; VACHON, C.; LACROIX, M. Irradiation dose and calcium effect of the mechanical properties of cross-linked caseinate films. Journal of agricultural and food chemistry. v. 46, n.4, p. 1618-1623, 1998.

RHIM, J.W.; PERRY K.W. Ng. Natural Biopolymer-Based Nanocomposite Films for Packaging Applications. Critical reviews in food science and nutrition, $v$. 47, n. 4, p. 411 - 433, mai 2007.

RIBEIRO, E.P.; SERAVALLI, E.A.G. Química de alimentos. São Paulo: Editora Edgard Blücher Ltda: Instituto Mauá de Tecnologia, 2004.

SALMORAL, E.M.; GONZALEZ, M.E.; MARISCAL, M.P. Biodegradable plastic made from bean products. Industrial crops and products. v. 11, p. 217-225, 2000.

SARMA, K.S.S.; SABHARWAL, S. Radiation processing of polymers with high energy electron beams: novel materials and processes. Trombay, Mumbai: Radiation technology development section, 2002.

SATHIVEL, S. Chitosan and protein coatings a.ect yield, moisture loss and lipid oxidation of Pink Salmon (Oncorhynchus gorbuscha) fillets during frozen storage. Journal of food science, v. 70, p. E455-E459, 2005.

SATIN, M., Food Irradiation: A Guidebook. Technomic Publishing Company, Inc., Lancaster, PA, U.S.A., 1993. 
SAUERMANN P. Ermittlung der innernen Strahlenbelastung durch Messung der $\mathrm{K} u$ rperaktivitd $t$. Forschungzentrum $\mathrm{Jb}$ lich/Deutschland. Chernobyl-Wilsede-Meetung. Gomel/Korma (Belarus). p. 21 - 24, Aug., 1995.

SCHRIEBER, R.; GAREIS, H. Gelatine handbook: theory and industrial practice. New York, N.Y.: Wiley-VCH, 2007. Disponível em: <http://www.wiley.com/WileyCDA/WileyTitle/productCd-3527315489.html>.

Acesso em: 29 nov. 2007.

SIMÃO, A.M. Aditivos para alimentos sob o aspecto toxicológico. São Paulo: Nobel, 1985.

SKINNER, E.R.; KERTESZ, Z.I. The effect of gamma radiation on the structure of pectin. An spectrophoretic study. Journal of polymer science. V. 47, p. $99-109,1960$.

SLETMOEN, M.; MAURSTAD. G.; STOKKE, B.T. Potentials of bionanotechnology in the study and manufacturing of self-assembled biopolymer complexes and gels. Food hydrocolloids. v. 22, n. 1, p. $2-11$, Jan. 2008.

STEVEN, A. M. In Other Plant Polysaccharides. Aspinal, G. O. Ed. The polysaccharides, New York: Academic Press. V. 2, p. 154 - 161, 1983.

STREETER, V.L. Mecânica dos fluidos. São Paulo: McGraw-Hill do Brasil Ltda, 1974.

STUCHELL, Y. M.; KROCHTA, J. M. Edible coating on frozen king salmon: effect of whey protein isolate and acetylated monoglycerides on moisture loss and lipid oxidation. Journal of food science, v. 60, p. 28 - 31, 1995.

SUDHAKAR, D.V.; MAINI, S.B. Isolation and characterization of mango peel pectins. Journal of food processing and preservation. v. 24, n. 3 , p. 209 - 227, Aug. 2000.

SURÓWKA K. Effect of protein hydrolysate on the instrumental texture profile of gelatin gels. J Texture Stud. v. 28, p. 289 - 303, 1997.

TERAO, K.; NAGASAWA, T.K.; NISHIDA, H.; FURUSAWA, K.; MORI, Y.; YOSHII, F.; DOBASHI, T. Reagent-free crosslinking of aqueous gelatin: manufacture and characteristics of gelatin gels irradiated with gamma-ray and electron beam. J. Biomater. Sci. Polym. v. 14, n. 11, p. 1197 - 1208, 2003.

THAKUR, B.R.; SINGH, R.K.; HANDA, A.K. Chemistry and uses of pectin - a review. Critical reviews in food science and nutrition, v. 37, n. 1, p. $47-73$, 1997.

ULANSKI, P.; JANIK, I.; ROSIAK, J.M. Radiation formation of polymeric nanogels. Radiation physics and chemistry. v. 52, n. 1-6, p. 289-294, June 1998. 
VACHON, C.; D' APRANO, G.; LACROIX, M.; LETENDRE, M. Effect of edible coating process and irradiation treatment of strawberry fragaria ssp. On storage-keeping quality. Journal of food science. v. 68, n. 2. p. $608-612$, 2003.

VAN NIEUWENHUYZEN, W.; BUDNIK, V.; MEIER, T.; POPPER, L. Functional use of hydrocolloids in food systems. Agro food industry hi-tech, v. 17, n. 5, p. $39-43,2006$.

VERMEIREN, L.; DEVLIEGHERE, F.; VAN BEEST, M.; KRUIJF, N. de; DEBEVERE, J. Developments in the active packaging of foods. Trends food science and technology. v. 10, p. 77 - 86, 1999.

VIEIRA, F.F., MASTRO, N.L. Comparison of $\gamma$-radiation and electron beam irradiation effects on gelatin. Radiation physics and chemistry. v. 63, p. $331-332,2002$.

VON SONNTAG, C. Free-radical reactions of carbohydrates as studied by radiation techniques. Adv. Carbohydr. Chem. Biochem., v. 37, n. 7, 1980.

VON SONNTAG, C. Trends of research in radiation chemistry. In: IAEA. Advanced radiation chemistry research: current status. IAEA-TECDOC-834. International Atomic Energy Agency, Vienna, p. 11 -41, 1995.

WAHBA, I.J.; TALMAN, D.F.; MASSEY, LM. Radiation-induced gelation of dilute aqueous pectin solutions. Science, v. 139, n. 356, p. $1297-\&, 1963$.

WHISTHER, R.L.; BEMILLER J.N. Carbohydrate chemistry for food scientists. St. Paul, M.N.: The American Association of Cereal Chemists, Inc, p. $203-210,1997$.

WHO. Technical Report Series No. 890. High-Dose Irradiation: Wholesomeness of Food Irradiated with Doses Above $10 \mathrm{kGy}$. Report of a Joint FAO/IAEA/WHO Study Group. World Health Organization, Geneva, 1999.

WINDHOLZ, M. (Ed.); BUDAVARI, S. (Co-Ed.); BLUMETTI, F.R.; OTTERBEIN, E.S. The merck index. 10. ed. New Jersey, N.J.: Merck \& Co, Inc, p. 1013, 1983.

WONG, D.W.S. Química de los alimentos: mecanismos y teoría. Zaragoza, Esp.: Acribia S.A., 1995.

YANG, H.; WANG, Y.; REGENSTEIN, J.M.; ROUSE, D.B. Nanostructural characterization of catfish skin gelatin using atomic force microscopy. Journal of food science. v. 72, n. 8, p. C430-C440, 2007.

YANG, Y.L.; ZHOU, G.H.; XU, X.L.; WANG, Y. Rheological properties of myosin-gelatin mixtures. Journal of food science. v. 72, n. 5, p. C270 - C275, 2007. 
YOSHIMURA, T.; SENGOKU, K.; FUJIOKA, R. Pectin-based superabsorbent hydrogels crosslinked by some chemicals: synthesis and characterization. Polymer bulletin. v. 55, p. 123-129, 2005.

YU, Y.; WANG, J. Effect of $\gamma$-ray irradiation on modeling equilibrium moisture content of wheat. Journal of food science. v. 72, n. 8, p. E405 - E411, 2007.

ZEGOTA, $\mathrm{H}$. The effect of $\gamma$-irradiation on citrus pectinin $\mathrm{N}_{2} \mathrm{O}$ and $\mathrm{N}_{2} \mathrm{O} / \mathrm{O}_{2}$ satured aqueous solutions. Food hydrocolloids. v. 13, p. 51 - 58, 1999.

ZHOU, P.; MULVANEY, S.J.; REGENSTEIN, J.M. Properties of Alaska pollock skin gelatin: comparison with tilapia and pork skin gelatins. Journal of food science. v. 71, p. C312 - C321, 2006.

ZHOU, P.; REGENSTEIN, J.M. Comparison of water gel desserts from fish skin and pork gelatins using instrumental measurements. Journal of food science. v. 72, n. 4, p. C196 - C201, 2007. 